\title{
Last Interglacial sea-level data points from Northwest Europe
}

\author{
Kim M. Cohen ${ }^{1}$, Víctor Cartelle ${ }^{2}$, Robert Barnett ${ }^{3}$, Freek S. Busschers ${ }^{4}$, Natasha L.M. Barlow ${ }^{2}$ \\ ${ }^{1}$ Department Physical Geography, Utrecht University, PObox 80.115, 3508TC Utrecht, Netherlands \\ ${ }^{2}$ School of Earth and Environment, University of Leeds, Woodhouse Lane, Leeds LS2 9JT, United Kingdom \\ $5{ }^{3}$ Department of Geography, University of Exeter, Rennes Drive, Exeter EX4 4RJ, United Kingdom \\ ${ }^{4}$ TNO Geological Survey of the Netherlands, PObox 80.015, 3508TA Utrecht, The Netherlands \\ Correspondence to: Kim M. Cohen (k.m.cohen@uu.nl)
}

Abstract. Abundant numbers of sites and studies exist that document the Last Interglacial (Eemian, Ipswichian, MIS 5e) coastal record for geographically and geomorphologically diverse NW Europe. This paper documents a database of 141 known Last Interglacial sea-level indicative data points from in and around the North Sea (35 entries in Netherlands, 10 Belgium, 16 in Germany, 17 in Denmark, 8 in Britain) and the English Channel (28 entries for British and 25 for the French side, 3 on the Channel Isles), believed to be a representative and fairly complete inventory and assessment coming from some 80 published sites. The good geographic distribution (some $1500 \mathrm{~km} \mathrm{SW-NE)} \mathrm{across} \mathrm{the} \mathrm{near} \mathrm{field} \mathrm{of} \mathrm{the} \mathrm{Scandinavian}$ and British Ice Sheets and the attention paid to absolute and relative age control are assets of the NW European database compilation. The research history of Last Interglacial coastal environments and sea-level position for this area is long, methodically diverse and spread over regional literature in several languages. Last Interglacial high-stand shorelines of Dutch and German Bight parts of the North Sea, were of lagoonal and estuarine type and have preserved subsurface (data entry included estimates of non-GIA vertical land motion). In contrast, Last Interglacial high-stand shorelines along the English Channel are encountered above modern sea-level (data entry includes datum definitions). Our review and database

20 compilation effort drew from the original regional literature, and paid particular attention to distinguishing between sea-level index points (SLIPs) and marine and terrestrial limiting-points.

This paper describes the dominant sea-level indicators produced from region to region, compliant to the database structure of the special issue (WALIS), referenced to original source data. The sea level proxies in majority are obtained from localities with well-developed lithostratigraphic, morpho-stratigraphic and biostratigraphical constraints. Amino-Acid Racemization information is also prominent, especially in Britain, albeit for many sites the older, lesser quality applications of that technique. The majority of European continental sites have chronostratigraphic age-control, notably through regional Pollen Association Zones of known durations. This greatly helps to separate transgression, highstand ('stillstand') and regression subsets from within the interglacial, useful when summarizing and/or querying the dataset. In all regions, many SLIPs and 30 limiting points have further independent age-control from luminescence (IRSL, OSL, TL), U-series and ESR dating techniques. Main foreseen usage of this database for the near field region of the European ice sheets is in GIA modelling. 
https://doi.org/10.5194/essd-2021-390

Preprint. Discussion started: 10 November 2021

(c) Author(s) 2021. CC BY 4.0 License.

(c) (i)

\section{Introduction}

Near-field records of Last Interglacial (LIG; 130-116 ka) sea level, proximal to the location of palaeo ice sheets, are critical for establishing improved reconstructions of past ice sheets, constraining models of solid Earth processes and fingerprinting the source of ice sheet melt (Dutton et al., 2015; Long et al., 2015). However, the near-field LIG sea level has received comparable little attention compared to the far-field due to the challenges of dating estuarine sequences and the complications of regional glacial isostatic adjustment (GIA). The main aim of this paper is to describe a standardized database of geological sea-level proxies, compiled using the tools available through the World Atlas of Last Interglacial Shorelines (WALIS) project for north west (NW) Europe, in particular around the North Sea and English Channel region.

40 This is a location that is proximal an extensive MIS 6 Eurasian ice sheet (e.g. Svendsen et al. 2004; Ehlers and Gibbard, 2004; Lambeck et al., 2006; Lang et al., 2018) and has a long history of Quaternary palaeoenvironmental research (e.g., Dixon, 1850; Harting, 1874).

The thickness and nature of the LIG coastal geomorphology and sedimentary sequences in NW Europe varies considerably.

45 In the North Sea coastal region (e.g. Netherlands, offshore in the North Sea, NW Germany and SW Denmark), key sites are meter-thick infills of topographic depressions in deglaciated terrain, between the maximum ice-margins of the Saalian glaciation (MIS 6) and that of the Last Glacial (Fig. 1) (e.g. Zagwijn, 1983; Streif, 2004; Beets et al., 2005; Konradi et al., 2005). Along the English Channel many LIG sites comprise of flights of raised beaches, e.g. West Sussex coastal plain, southern England (Bates et al., 2010) and Cotentin, northwest France (Coutard et al., 2006). Both along the North Sea and

50 along English Channel, the mouths of rivers record transgressed palaeovalleys and provide opportunities to constrain the regional LIG sea-level highstand (e.g. Antoine et al., 2007; Briant et al., 2012; Bogemans et al., 2016; Peeters et al., 2016).

Due to the extensive history of palaeoenvironmental research in this region, many of the sites documented here were studied $50+$ years ago, by experts in microfossil and sedimentological analysis rather than with a focus on establishing sea level 55 index points (SLIPs) under now well-developed frameworks (Rovere et al., 2016; van de Plassche, 1986; Hijma et al., 2015). That wealth and history of research is both its strength and a challenge when compiling a database for NW Europe's North Sea and English Channel coastlines.

Figure 1 (next page) Overview of study area with data points (legend groups cf. Section 5) and Setting / Palaeogeographical 60 context. North Sea and English Channel coastlines and lower reaches of main rivers depict situation at Last Interglacial highstand (newly compiled as part of data screening effort, matching regional reconstructions provided in main SLR data source papers). Ice-limits for the penultimate and last glacial cycles in area of LIG data points similarly compiled from regional studies (Ehlers et al., 2004; Busschers et al., 2008; Moreau et al., 2012; Lang et al., 2018; Gibbard et al., 2018; Cartelle et al., 2021) and adjoined to superregional overviews (Ehlers and Gibbard, 2004; Batchelor et al., 2019). Pleistocene depocentre in North Sea indicated: see

65 Section 4.3. Axis used to arrange presentation in Figs. 5 and 6 indicated. Selection of topographic names from text included, offshore sites with informal short ids from source papers. Bathymetry and DEM backdrop: EMODnet Bathymetry Consortium (2020), their WMS-service which incorporates land data () OpenStreetMap contributors 2020, distributed under the Open Data Commons Open Database License (ODbL) v1.0. 
https://doi.org/10.5194/essd-2021-390

Preprint. Discussion started: 10 November 2021

(c) Author(s) 2021. CC BY 4.0 License.

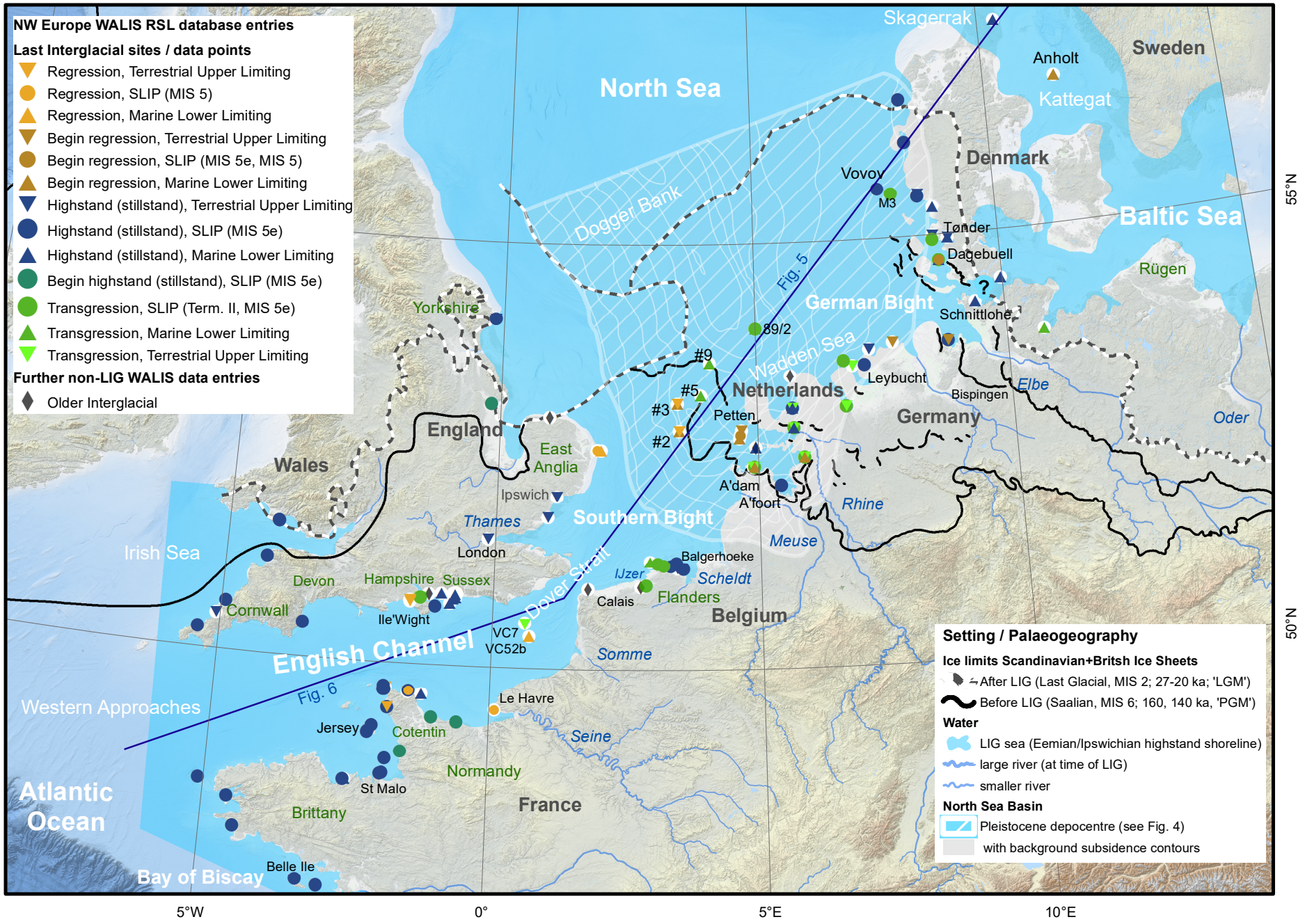


https://doi.org/10.5194/essd-2021-390

Preprint. Discussion started: 10 November 2021

(c) Author(s) 2021. CC BY 4.0 License.

(c) (1)

70 Table 1 Global and regional time division schemes

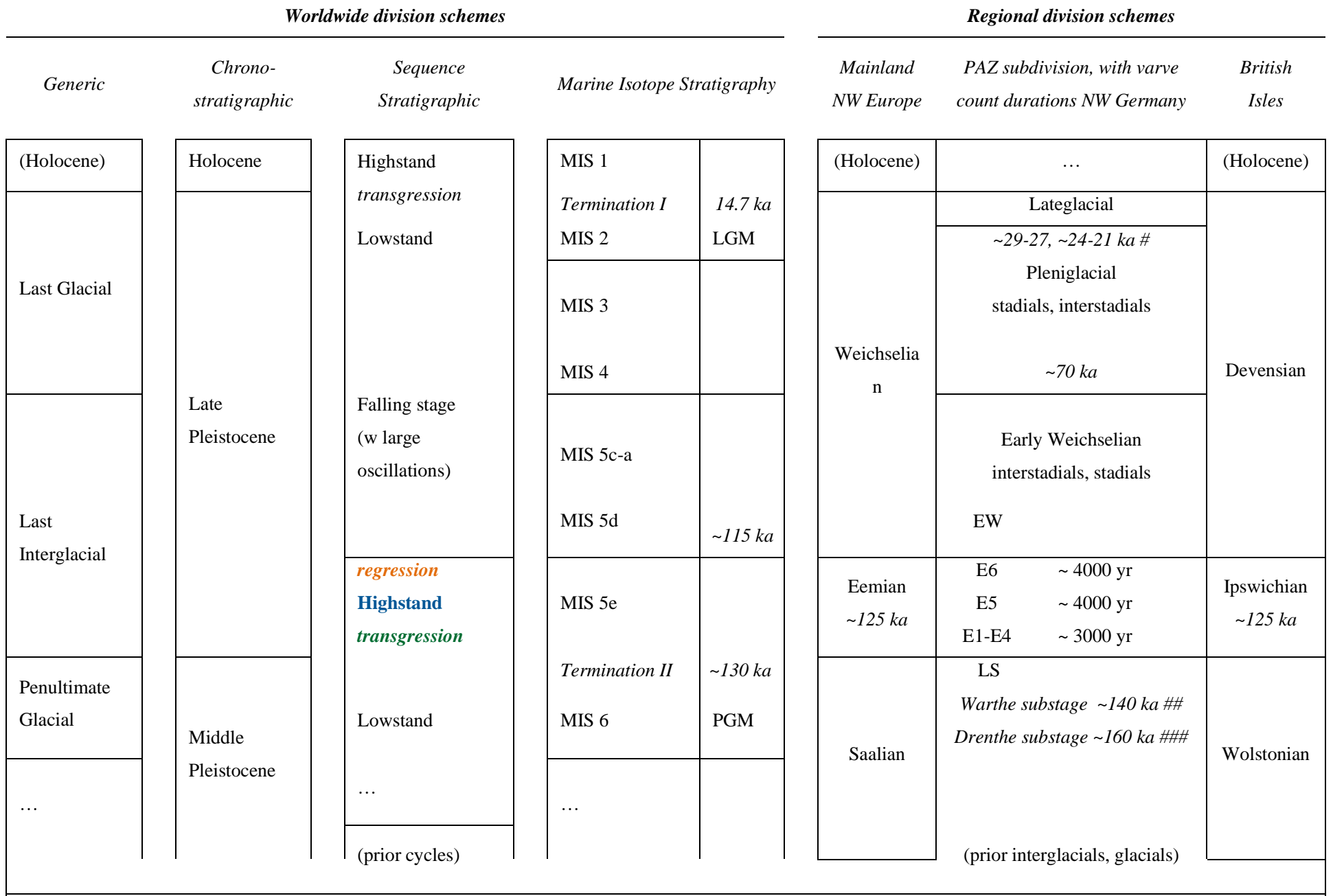

Schemes follows Cohen \& Gibbard, 2019. The palynological subdivision column adds E1-E6 durations of Müller (1974), Zagwijn (1983, 1996).

* Termination midpoints are MIS stage boundary (Shackleton 1969; Lisiecki \& Raymo, 2005; Railsback et al. 2015).

\# Last Glacial glaciation of the study area reaching maxima within MIS 2 and MIS 4. Limits over NE Germany, Denmark and central North Sea (Fig. 1)

\#\# Warthe substage, with Scandinavian limit just beyond Last Glacial ones in German Bight and onshore (Fig. 1). Offshore landforms LIG transgressed.

\#\#\# Drenthe substage, with Scandinavian limit furthest SW across North Sea, Netherlands and Germany onshore (Fig. 1). Offshore landforms LIG transgressed.

The paper covers the study area region-by-region, starting with the North Sea coast of the Netherlands, Belgium, the German

75 Bight, Denmark and the Danish-German SE of the Baltic sea (compiled by KMC), then the British North Sea coast (Thames Estuary, East Anglia and North England; compiled by NLMB) and offshore records in the British North Sea (complied by 
VC), then the British (Southern and Southwest Britain; compiled by RB) and French (Normandy and Brittany; compiled by VC) sides of the English Channel. In NW Europe, age control on LIG estuarine deposits typical relies on relative dating based on micro- and macro-fossil biostratigraphy, and amino-acid racemisation (AAR) of fossil material due to the nature of the fine-grained silt, clay and organic sediments. More recently studied, or revisited, sites may have absolute OSL or Useries ages where the stratigraphy permitted. Differences in geological-geomorphological settings along and between these large stretches of coast, tabulated in Table 2, have influenced depth of preservation, surveying and mapping strategies, preservation and taphonomy characteristics of typical sites and so on, and hence are touched upon repeatedly in this research history and dataset documentation (mostly in sections 2 and 5). In turn, this strongly influenced our region-by-region strategies for WALIS data entry (described in sections 3 and 4). For example, where regionally extensive Saalian glaciation landforms or tills are identified (Fig. 1), this identifies overlying marine deposits as Last Interglacial directly (areas with 'paraglacial' geomorphic control; Table 2). Away from the MIS-6 glaciated areas, however, this benefit is lost and identifying depositional record from the LIG can become ambiguous. The geographical differences also echo through in the discussion of NW Europe LIG sea-level data quality (age control, vertical control) towards the end of the paper.

Table 2: NW Europe WALIS data point totals, split by region.

\begin{tabular}{|c|c|c|c|c|c|c|c|c|}
\hline \multirow[t]{2}{*}{ Region } & \multirow[t]{2}{*}{ Quaternary Terrain } & \multirow[t]{2}{*}{ Main Age control } & \multicolumn{3}{|c|}{ Last Interglacial } & \multicolumn{3}{|c|}{ Older Interglacials } \\
\hline & & & SLIPs & $\begin{array}{l}\text { Mar. } \\
\text { limit. }\end{array}$ & $\begin{array}{l}\text { Ter. } \\
\text { limit. }\end{array}$ & SLIPs & $\begin{array}{l}\text { Mar. } \\
\text { limit. }\end{array}$ & $\begin{array}{l}\text { Ter. } \\
\text { limit. }\end{array}$ \\
\hline \multicolumn{9}{|l|}{ North Sea } \\
\hline N Netherlands & Saalian (MIS 6) paraglacial*. Substrate & Glaciogenic underlain*; & 12 & 12 & 11 & 2 & 0 & 0 \\
\hline Central NL lagoon & is further Quaternary sedimentary & PAZs; Lusi. biota.; OSL, & & & & & & \\
\hline Rhine estuary & basin fill. & AAR & & & & & & \\
\hline Belgium & Never glaciated. Quaternary valleys & PAZs, OSL & 8 & 1 & 1 & 1 & 0 & 0 \\
\hline Scheldt estuary & and marine platforms cut into & & & & & & & \\
\hline & Paleogene clays and sands & & & & & & & \\
\hline NW France & Never glaciated. Cliffs, beaches, & TL/OSL & & & & 1 & 0 & 0 \\
\hline Calais & abrasion platforms, cut into Chalk and & & & & & & & \\
\hline & locally older substrate. & & & & & & & \\
\hline German Bight (GER) & Saalian (MIS-6) paraglacial*. & Glaciogenic underlain*; & 6 & 2 & 5 & & & \\
\hline Wadden Sea & Substrate is further Quaternary & PAZs & & & & & & \\
\hline Elbe estuary & sedimentary basin fill. & & & & & & & \\
\hline SW Denmark & Saalian (MIS-6) paraglacial*. & Glaciogenic underlain*; & 6 & 2 & 3 & & & \\
\hline 'Bakkeoer' & Substrate is further Quaternary & PAZs; FAZs; AAR; & & & & & & \\
\hline & sedimentary basin fill. & Lusi. biota. & & & & & & \\
\hline N Denmark & Last Interglacial equivalent of & Glaciogenic under and & 0 & 6 & 0 & & & \\
\hline Skagen, Anholt & Skagerrak; Last-Glacial ice-overridden & overlain; FAZs; Lusi. & & & & & & \\
\hline & and GIA rebound affected. & Biota, AAR & & & & & & \\
\hline
\end{tabular}




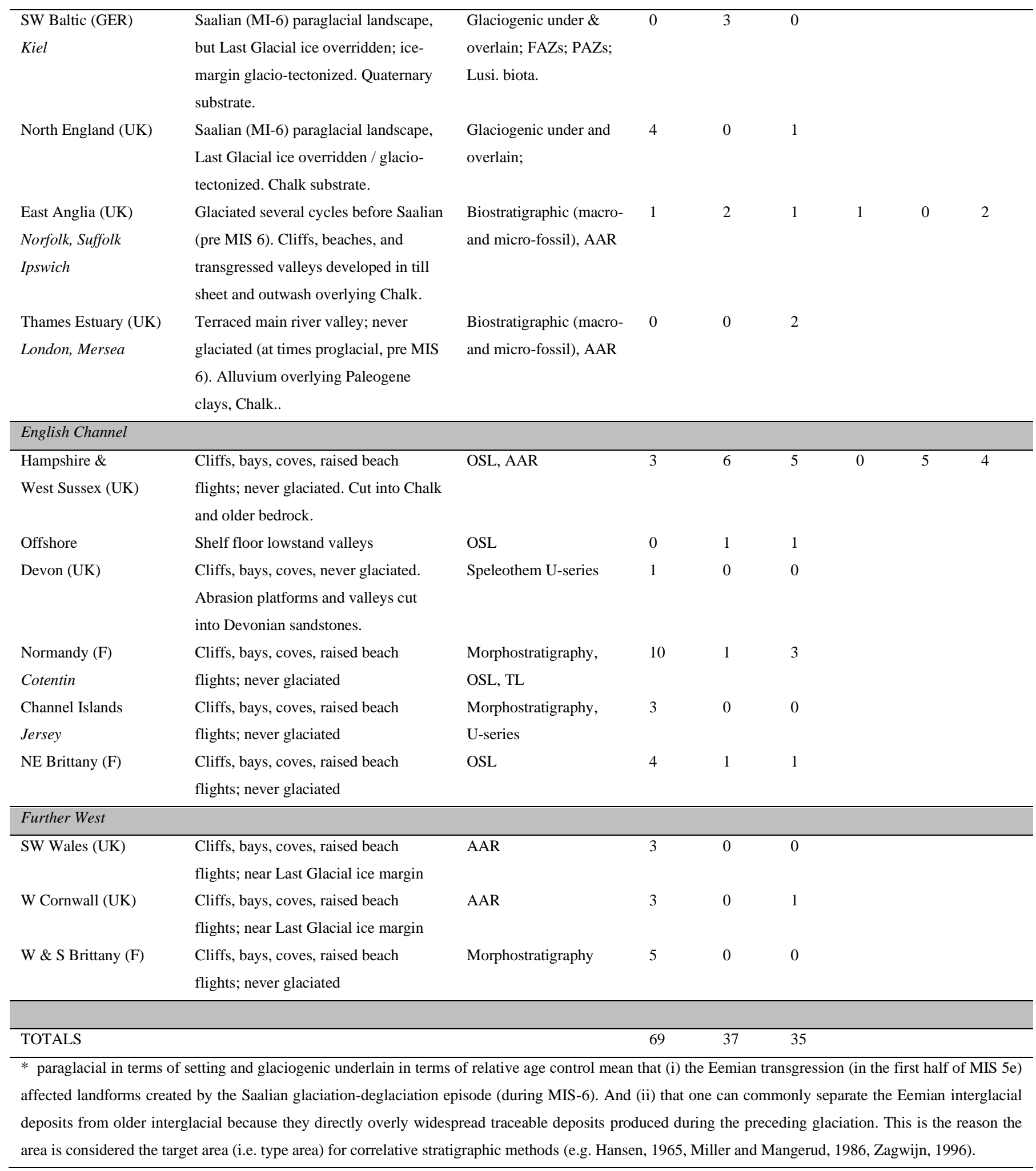


https://doi.org/10.5194/essd-2021-390

Preprint. Discussion started: 10 November 2021

(c) Author(s) 2021. CC BY 4.0 License.

(c) (i)

\section{Literature overview}

The dataset documented in this paper comes from several countries and physiographically diverse lengths of LIG coastline.

95 The research history on the subject is long, going back to the $19^{\text {th }}$ century when marine molluscan biostratigraphic evidence identified the buried Last-Interglacial equivalent of the North Sea (Harting, 1874; Lorié, 1906; Nordmann, 1928), and along the south coast of England (Dixon, 1850; Reid, 1898). Last-Interglacial deposits have been studied intensively during the $20^{\text {th }}$ century (e.g. Zagwijn, 1961; Müller, 1974; Menke and Tynne, 1984), which gradually established the 'Eemian' (though widely termed the 'Ipswichian' in British regional literature, Table 1) as a superregional chronostratigraphic unit (e.g. Zagwijn, 1996; Turner, 2000), more or less equivalent to the LIG and MIS 5e (e.g. Cohen and Gibbard, 2019). As such, its onset, acme and terminus of the interglacial became a correlation target across Europe and the North Atlantic in terrestrial climatological studies (e.g. Tzedakis, 2003; Sirocko et al., 2005; Helmens et al., 2015), as well as in glaciological (e.g. NEEM community members, 2013), oceanographic (e.g. Bauch et al., 2011), and shallow and coastal marine research (e.g., Long et al., 2015).

For reasons of brevity and focus, we restrict the literature overview here to studies addressing LIG relative sea level (RSL) positions. Note that there is also a wealth of LIG terrestrial sites in the UK and mainland Europe, many of which have been used to understand regional climatic and environmental change during the LIG (Behre et al., 2005; Kühl et al., 2007; Candy et al., 2016). In the database entry, we restricted ourselves to the lowest elevated terrestrial-only sites that serve in sea-level reconstructions as 'terrestrial limiting' data points. Adding higher elevated sites, as close to modern and palaeocoastlines as they may be spatially (e.g. Folkestone Battery at +27 m OD; Bridgland et al., 1995b), provides no added constraint to sealevel reconstruction. Discussion of older interglacial only serves to separate and unmix them from LIG inventory, in the present state of research.

\subsection{North Sea: Netherlands onshore and offshore}

115 A key paper and starting point for any literature overview on LIG sea-level indicator points in the southern North Sea, is that by Zagwijn (1983) entitled Sea-level changes in the Netherlands during the Eemian. The paper draws comparison with Holocene RSL reconstruction in the same region, but more so informs (i) the setting of the Eemian deposits amidst Saalian glacial landforms (Table 2), and (ii) the relative age control within the interglacial as offered by regional pollen assemblages ('pollen association zones', PAZs) of know durations (PAZs E1-E6; Table 1), as they became established by Zagwijn and Danish, British and German counterparts between the 1920s to 1980s (e.g. Jessen and Milthers, 1928; Müller, 1974; Menke and Tynne, 1984). All Zagwijn's considered locations, are positioned north of the Saalian maximum glaciation limit: transgressive and highstand sites either overly Saalian tills and outwash (North Sea sites, N Netherlands sites) or are from along tongue-basin/push-moraine embayments (central Netherlands sites). The falling stage sites are from the Rhine estuary. 
https://doi.org/10.5194/essd-2021-390

Preprint. Discussion started: 10 November 2021

(c) Author(s) 2021. CC BY 4.0 License.

(c) (i)

This river in the Late Saalian, Eemian and Early Weichselian was positioned north of the Saalian limit separate from the

Meuse (Fig. 1), unlike in the Holocene situation (Van der Meene and Zagwijn, 1978).

The paper's summary diagram (reproduced in Fig. 2a) is a curve connecting 8 data-bars on a schematic time axis, which Zagwijn (1996) replotted as 9 data points on a linear time axis (durations established via varve counts at a site in NW Germany by (Müller, 1974) with PAZ E1-E6 totalling some 11,000 years, but floating on an absolute timescale. It encompasses a period of rising RSL (>20 m within 1000 years), a slowdown and highstand (over ca. 6000 years) and a sea level drop during the late interglacial and Early Weichselian. These data points have been included in many later global data compilations (e.g. Kopp et al., 2009), but because the absolute age of the E1-E6 scheme is ill constrained and remains debated (see section 6.1), different authors have used and placed the start of the RSL curve at different points ranging from $\sim 130 \mathrm{ka}$ to $\sim 120 \mathrm{ka}$ (discussed further in Long et al., 2015).

Zagwijn's RSL curve plots 'high-tide levels' and during PAZ E5 plateaus at -8 m MSL for the inland most site Amersfoort (Fig. 1). In plotting the data and constructing the curve, no vertical corrections were applied. The inland highstand, however, is from a more gradually subsiding part near the edge of the North Sea basin, whereas the seaward sites used to trace transgressive and falling stage sea levels are from locations closer to and over the Pleistocene depocenter (Fig. 1). The latter sites experienced greater rates of background (i.e. non-GIA) subsidence since depositions, for which one should correct vertical positions (see also section 4.2.1) when the data is to be used in global assessments evaluating ice loading/unloading history and sea-level response (WALIS database's application goal). Correction for vertical land motion (VLM) reduces the earlier quoted value for the rate of sea-level rise during E3 from ' $>20 \mathrm{~m} / \mathrm{kyr}$ ' to ' $>12 \mathrm{~m} / \mathrm{kyr}$ ', bringing it more in line with rates seen in the southern North Sea at the onset of the Holocene (Vink et al., 2007; Hijma and Cohen, 2019). Most adoptions of the 1983 curve in the later literature tie the Zagwijn-1983 data points to individual locations and apply differential vertical corrections (e.g. Lambeck et al., 2006; Kopp et al., 2009), for which basin subsidence values in Kooi et al. (1998) are typically used. The datasets likewise has included VLM specification for the North Sea basin sites (Section 4).

In the late 1980s, offshore investigations with participation of geological surveys from all North Sea countries revealed the location of the initial Eemian transgression well offshore the northern Netherlands (Sha et al., 1991; Beets et al., 2008; site BH89/2). New datapoints also became available from the NE Netherlands, from geological survey mapping campaigns (Ter Wee, 1979; Bosch, 1990). In 1990s the infill and setting of the Amsterdam and Amersfoort basins were subject of detailed multi-proxy studies, aiming to resolve the course of events of the Saalian deglaciation and the establishment of the Eemian interglacial optimum (Van Leeuwen et al., 2000; Cleveringa et al., 2000). Focus was on chronostratigraphy, 155 paleoclimatology and general depositional history more so than on improving reconstruction of past sea level. A crosssection from the centre to the southeastern rim of the Amsterdam Basin (De Gans et al., 2000) confirmed the presence of intertidal deposits from the Eemian highstand, echoing Zagwijn (1983) observations along the rim of the Amersfoort Basin. 
At this time, amino acid racemisation (AAR) dating of marine mollusca shells was performed on newly collected and archived materials (Miller and Mangerud, 1986), confirming the Eemian age of the offshore and onshore mollusc bearing 160 beds in Zagwijn (1983). Older interglacial marine levels do occur below the Saalian glaciation contact and associated deposits, which produced older AAR results.

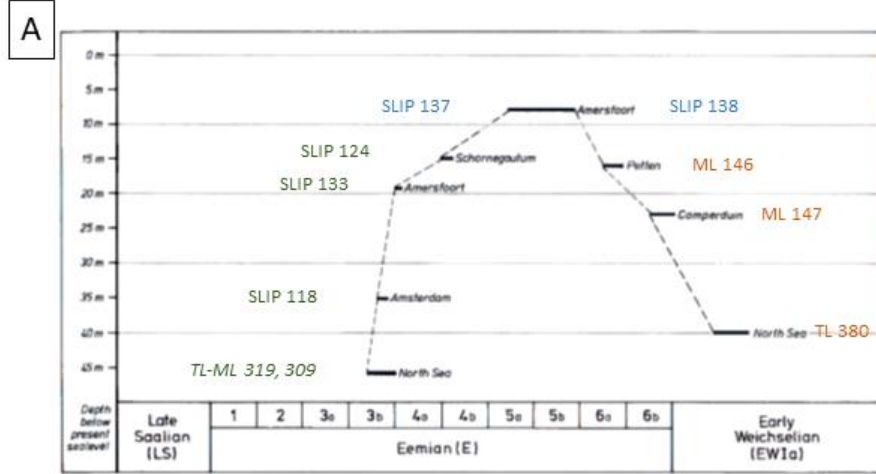

Sea-level curve Eemian of the Netherlands. Zagwijn, 1983

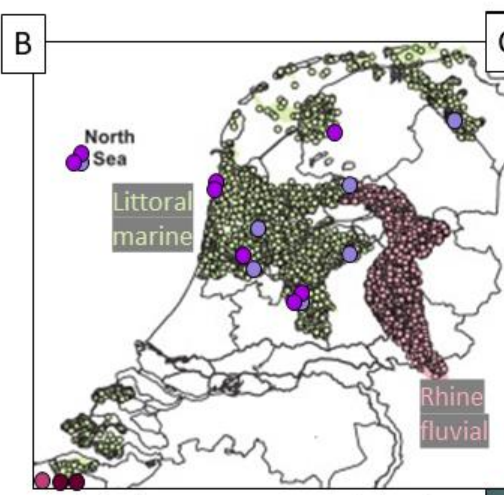

Borehole density NL. Peeters et al. (2015)

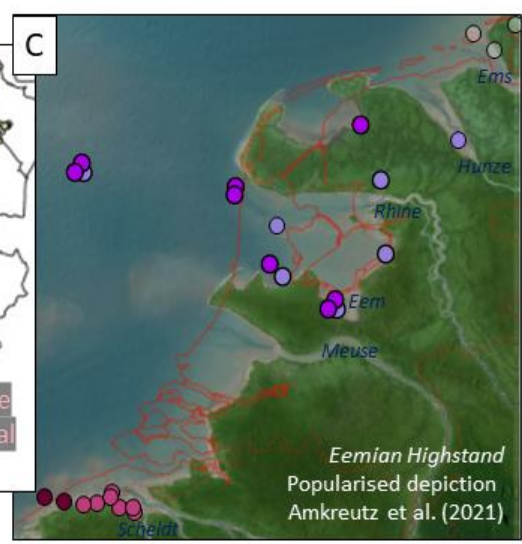

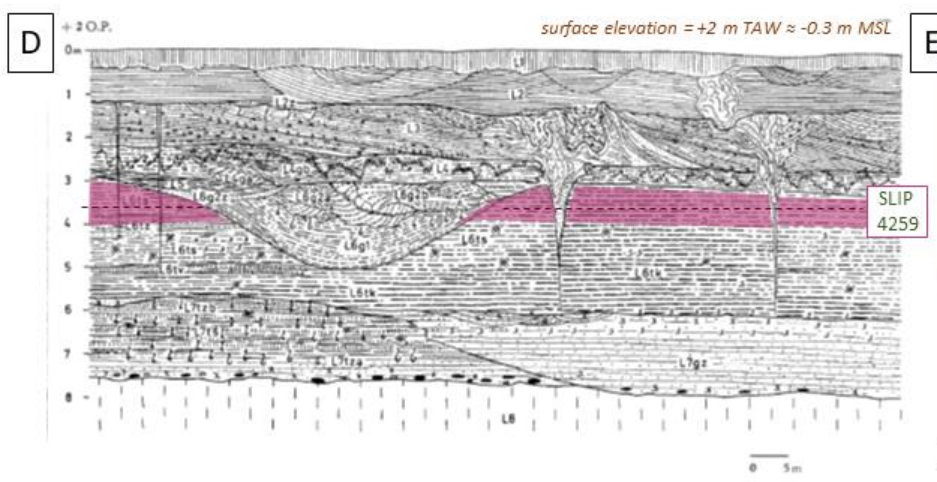

Meetkerke pit, section drawing. De Moor and De Breuck (1973), Nolf, (1973)

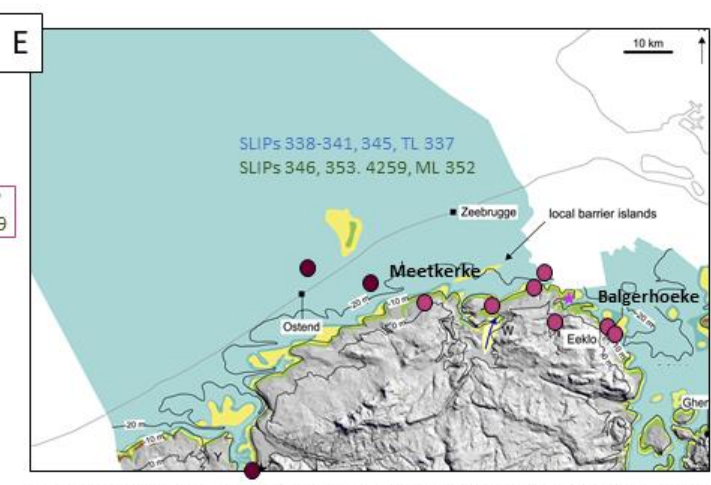

High Stand palaeogeography Flanders, Belgium. De Clercq et al., 2019
WALIS LIG data points highstand stillstand transgressive regressive SLIP sea level index point ML marine lower limit. pt TL terrestrial upper limit. pt Netherlands

Zagwijn-83 Since 1983 Belgium

dM\&dB 1973 Heyse 1979

Since 1979 165

Figure 2 Selected figures illustrating research history and database contents for The Netherlands (panels A-C) and Belgium (panels D-E), with annotations (database IDs, grouping in transgression, stillstand, highstand). A) sea level curve of Zagwijn (1983) B) Borehole density for the Netherlands (Peeters et al., 2015) overlain with legacy and more recent RSL data points. C) Popularised depiction of Eemian Highstand (Doggerland exhibition, Rijksmuseum voor Oudheden, Leiden; Amkreutz et

170 al., 2021). D) Exposure drawing of pit Meetkerke, Belgium (De Moor and De Breuck, 1973), elevation of SLIP highlighted. E) Paleogeographical map for Eemian highstand in Flanders, for a series in De Clercq et al. (2018). Panels reproduced with permission (A-E: Stichting NJG; Elsevier; RMO/Odé; present holder unknown, archived by Vliz.be; Wiley).

175 Since the late 1990s, investigation concentrated on the sedimentary development and chronostratigraphy of the river Rhine during the Late Saalian, Eemian and Weichselian (Table 1). Initially, this focused on areas south of the Saalian maximum ice limit (Törnqvist et al., 2000; Wallinga et al., 2004; Busschers et al., 2005, 2007; Hijma et al., 2012), where falling RSL erosion and reworking dominated and hence no Eemian sea-level constraints are preserved (Fig. 1; Table 2). The research 
https://doi.org/10.5194/essd-2021-390

Preprint. Discussion started: 10 November 2021

(c) Author(s) 2021. CC BY 4.0 License.

was important since the application of absolute optically stimulated luminescence (OSL) dating confirmed the correlation of the Saalian maximum glacial limit to a phase within MIS-6, and the timing of the Eemian climatic optimum and North Sea highstand in MIS 5e. The numeric age of the ice-limit landforms in the Netherlands and adjacent Germany was since corroborated by OSL-ages at tens of sites (Busschers et al., 2008; Lang et al., 2018) clustering around 170-150 ka (Table 1: Drenthe substage). Peak outwash sediment fluxes occurred at the same time in shelf-edge submarine deposits off the English Channel (Armorican fan; Toucanne et al., 2010). Between the Saalian maximum limit and that of the Last Glacial (Fig. 1), the glaciogenic terrain was formed between 160 and $130 \mathrm{ka}$ mainly (Warthe submaximum at $140 \mathrm{ka}$; Table 1) Transgressive and highstand coastal deposits onlap Saalian-age glaciogenic landforms and river valleys, or they onlap the floors and rims of valleys that dissected such landforms. OSL dates from within the Late Saalian and Eemian units confirm their deposition occurred between 140-110 ka (Busschers et al., 2007; Peeters et al., 2016).

190 The river Rhine significant shifted course during the late Quaternary, from its northerly route occupied during the Saalian deglaciation and throughout the Eemian, to the southerly course that it shares with the rivers Meuse and Scheldt . This shift explains the absence of preserved Eemian coastal sites in the subsurface of today's Rhine-Meuse delta immediately south of the Saalian glacial limit. In the last 10 years, the northerly Rhine course and the estuarine mouth that it developed during the Eemian have received significant research attention (Sier et al., 2015, Peeters et al., 2016; 2019), yielding two new sea-level sites at relative inland lagoon-rim positions: Rutten and Oosterwolde (Peeters et al., 2016). The classic Amersfoort locality (Zagwijn, 1983), of which the data collection goes back to Lorié (1906) and Zagwijn (1961), was re-cored in 1980/81 (Miller and Mangerud, 1986), in the 1990s (Cleveringa et al., 2000; two boreholes) and again in 2008-2015 (TNO Geological Survey of the Netherlands; Durham University, Utrecht University), but has not yet produced new sea-level indicators.

\subsection{North Sea: Belgium, Southern Bight}

200 LIG coastal intertidal deposits in Belgium are encountered at shallow depths along the inland rim of the modern coastal plain, typically separated from Holocene equivalents by periglacial deposits of Last Glacial age. From the very NW of Belgium, the monograph of Heyse (1979) provides a series of pit exposures, describing the sedimentology and palynology (using the E1-E6 scheme, as in The Netherlands). Further LIG deposits from estuarine environments are associated with valley fills underlying the Flanders coastal plain, the main one cut by the river Scheldt in Middle Pleistocene times

205 (Flemmish Valley; Gibbard, 1988; De Moor and Pissart, 1992), and in the SW a second one of same broad age cut by the river IJzer (Bogemans et al., 2016; hosting deposits of older interglacials too). De Moor and De Breuck (1973) and Nolf (1973) describe the tidal sedimentology resp. marine molluscan content of pit site Meetkerke (Fig. 2d), just west of Brugge. Authors Mathys (2009) and De Clercq et al., (2019) have mapped the onshore-offshore continuation of these valley systems, the former with morphostratigraphic attention (intersection of Last Glacial dissective phenomena of the Dover Strait;

210 Bridgland and D'Olier, 1995; Gupta et al., 2007), the latter with particular attention to palaeogeography in successive stages of sea-level rise and fall during the LIG (Fig. 2e). Compared to the fairly straight present-day coastline, the Eemian coast 
https://doi.org/10.5194/essd-2021-390

Preprint. Discussion started: 10 November 2021

(c) Author(s) 2021. CC BY 4.0 License.

(c) (i)

line is considered a more irregular one, with Paleogene clay hilly outcrops forming capes and islands. The cluster of sites documented by Heyse (1979), occupies a position just north of such an outcrop. River valleys functioned in the valleys before and after the LIG. As in most lower reach valley settings, the falling and lowstand stage induced considerable erosion to LIG deposits of the Belgian valley fills. Onshore, highstand deposits were left preserved just locally along valley rims. In the vicinity of the modern coastline, units from early transgressive stages did preserve locally below the falling stage erosive contacts. During youngest falling and low stand stages (Table 1), the Scheldt river established northwestward to northward valleys into the SW Netherlands (Vandenberghe, 1985), further explaining the degree of preservation of LIG deposits in the NW of Belgium and spatial distribution of WALIS entries for Belgium.

\subsection{North Sea: German Bight, NW Germany, SW Denmark}

LIG coastal deposition in and along the German Bight accumulated and preserved in very similar setting, as those of the central and Northern Netherlands. The research history also starts similarly early as in England and the Low Countries, with boreholes at Tønder (Madsen et al., 1908) and Højer (Nordman, 1928) in the Vidå valley particular classic sites. The area lay outside Scandinavian ice sheet coverage of the Last Glacial, though outwash produced along that margin was a major eroding and burying agent to the Eemian coastal record. The substrate for the Eemian transgression is hosted by landforms generated during the Saalian glaciation, deglaciation, readvance (Drenthe-2 and Warthe morainic lines) and (glacio-)fluvial dissection (conduits of Vidå, Eider, Elbe, Weser and Ems). Miller and Mangerud (1986) resampled sites from along the Danish Eemian North Sea. Streif (2004) summarised evidence around the German Bight, linking up to Dutch, Belgian and English North Sea coastal sectors, and providing intercomparison with older interglacials and the Holocene. Konradi et al. (2005), in their paper entitled Marine Eemian in the Danish eastern North Sea, provide palaeogeographical details for an inventory of sea-level indicator sites. They aptly characterise the Danish Eemian shoreline as 'more irregular than present' (Fig. 1). Some of the sea-level data points are reported from environments resembling those of the modern Wadden Sea, whereas others come from what would better be called 'fjords' and 'straits' cut in the Quaternary glacial and riverlain substrate of the freshly exposed glacial landscape at the onset of Eemian transgression. A palaeogeographical particularity is

235 a W-E marine highstand passage between German Bight and SW Baltic Sea across the German-Danish border (SchleswigHolstein), unlike the peninsular present situation (Winn and Erlenkeuser, 1995; Konradi et al., 2005; see section 2.4). Such a connection is suspected from geological mapping the dented inland extent of the German Bight Eemian highstand (e.g. at Schnittlohe, ID 889, N Germany; Menke 1985; Knudsen 1985) and from biotic changes in the SW Baltic halfway the regional extensive Cyprina Clay marine beds (Funder et al., 2002; see section 2.4), although the supposed connection would

240 have been shallow and is not fully traced and hence not evident (Miller and Mangerud, 1986; Kosack and Lange, 1985; Schulz et al., 2001 - op cit. Konradi et al., 2005).

Continued sea-level rise towards the Eemian highstand inundated good parts of the German Bight's Saalian glacial derived push-moraine and till-plateau islands (dubbed 'Bakkeør'), which were subsequently hidden by LGM and deglacial sediments 
https://doi.org/10.5194/essd-2021-390

Preprint. Discussion started: 10 November 2021

(c) Author(s) 2021. CC BY 4.0 License.

(c) (i)

and basin-tectonic and GIA subsidence. Between the Bakkeør-island series and the Danish mainland a retreat-stage meltwater plain is present, which steered the transgression in the Danish sector and drew considerable investigation (listed in Konradi et al., 2005:24). Southwest of the Bakkeø-islands/Warthe limit, lay the Elbe valley, an ice-marginal river during the Warthe ice-limit and the LGM, which formed an Eemian estuary preserving LIG sea-level indicators recorded by Menke and Tynni (1984); Menke (1985) and Streif (1990; 1991). West of the Elbe valley/estuary, a secondary morainic limit exists (Fig.

250 1; e.g. Ehlers et al., 2004), and the associated lows host intensively studied Eemian and Early Weichselian terrestrial deposits (Selle and Schneekloth 1965; Behre et al., 2005; key sites Oerel and Glinde). The northernmost, deepest sites also preserve evidence of marine incursions (Streif 1990, 2004). Further West, the till plateau of Ost-Friesland and minor valleys set into it host Eemian coastal deposits, similar to sites further west along the Wadden Sea in the Netherlands.

255 Largely age-control of the NW German and SW Danish sites (Table 2) is based upon pollen investigations on terrestrial beds immediately below and above tidal coastal deposits and contained in the brackish and saline deposits, resolving broad-scale vegetation succession (i.e. Zagwijn E1-E6 scheme; converted to from Danish and German origin schemes; e.g. Funder et al., 2002). Like in the Dutch sector, the Saalian deglaciated geological-geomorphological setting means identifying LIG from older interglacial deposits is relatively simple. Importantly, no inland fluvial-estuarine sites are known for the German Bight: falling RSL and lowstand erosional activity during the last glacial cycle (Table 1) appears to have mostly removed expected Eemian highstand morphostratigraphic records from along the valleys of Elbe, Weser and Ems. This is in contrast to the Rhine, Scheldt and Thames estuaries in the Dutch, Belgian and English LIG North Sea coastal segments.

\subsection{Skagerrak and SW Baltic: N Denmark, NE Germany - within the Last Glacial limit}

North and Eastward into Denmark, land and seafloors were ice covered during the Last Glacial, meaning that LIG coastal deposits were eroded and glaciotectonically displaced. In NE Denmark, deep boreholes on the Jutland peninsula and islands facing the Skagerrak-Kattegat embayment reveal thick marine sequences overlying Saalian-aged till and below Last Glacial erosive contacts, exclusively from relatively deep marine environments (Jessen et al., 1910; Bahnson et al., 1974; Knudsen and Lykke-Andersen 1982; Knudsen et al., 2009). These sequences record regional details of the oceanographic-climatic amelioration (warming, invading boreo-Lusitanian biota) at the onset of the LIG, as well as deterioration (cooling, returning boreal and subpolar biota) following the LIG, e.g. at Anholt (Seidenkrantz, 1993: Kattegat stadial just prior to beginning of Eemian), and Skaerumhede, North Jutland (Miller and Mangerud, 1986; Houmark-Nielsen, 1987; Larsen et al., 2009). At these locations, the Skagerrak-Kattegat seabed appears to have been overridden by Last Glacial ice, but only superficially eroded, and lower parts not laterally displaced. Similar to Holocene RSL evidence from the same region (raised beaches of Middle Holocene age at +12 m at Skagen Odde; Clemmensen et al., 2001; 2018; Rosentau et al., 2021), considerable GIA

275 vertical movement will have affected these north-easternmost sites in our compilation. Note that a separate regional LIG sealevel database paper will cover Scandinavian, Polish, Finnish, Baltic and Russian regions (Dalton et al., 2021/this special issue). 
https://doi.org/10.5194/essd-2021-390

Preprint. Discussion started: 10 November 2021

(c) Author(s) 2021. CC BY 4.0 License.

(c) (i)

In NW Denmark coastal marine Eemian deposits occur at shallower depths, not dissimilar to these in areas unaffected by glaciation in SW Denmark. Their positions within the Last Glacial limit and the level of disclosure that borehole-based subsurface mapping can give, however, means that some displacement cannot be excluded. Sites in this part of Denmark provide information on palaeocoastline positions (Fig. 1), but less so for reconstructing sea-level elevations (Konradi et al., 2005).

In SE Denmark, modern day cliff sections in glacial deposits on the isles facing the Baltic, such as Ristige Klint and Aero (Madsen et al., 1908), provide outcrops of shallow marine, coastal and near-coastal terrestrial beds, which have been extensively studied in a paleoenvironmental content (overview in Kristensen et al., 2000, Funder et al., 2002), and OSLdated (Murray and Funder, 2003; Buylaert et al., 2011). These sites allowed for fairly-detailed palaeoceanographic reconstruction for the Baltic Sea during the LIG, in particular what connections it maintained and established with the North Sea. The LIG marine deposits in the SW Baltic are known as the Cyprina Clay, which biota reveal to have evolved through a short initial brackish phase, and a longer twofold saline phase. The clay is heavily displaced and exposed in SE Danish coastal cliffs (Madsen et al., 1908; Kristensen et al., 2000), and stretches southwest and southeast into Germany with incursions near Lubeck, and outcrops at Rügen and Usedom (Madsen et al., 1908; Konradi, 1976; Houmark-Nielsen, 1987; Kubisch and Schoenfeld, 1985; Ruehberg et al., 1995; Winn et al., 2000).

For the SW Baltic Sea, mollusca and foraminifera associations at the base of the Cyprina-Clay, and geological mapping of N-S running straits separating the Danish Isles connecting the Baltic to the Kattegat (similar to the geography today), reveal transgressive marine connections along these N-S routes (Kristensen et al., 2000; Funder et al., 2002). As the interglacial unfolded, the salinity and temperature signals in the biota markedly change further (Kristensen et al., 2000) and, importantly for sea-level reconstruction, the connection across Schleswig-Holstein may have established (Funder et al., 2002). Pollen palynological investigations from the Cyprina Clay allow correlation of the SW Baltic oceanographic phases to the terrestrial forest succession schemes (Table 1), the brackish stage to PAZ E2b/E3a and division of the saline phase during PAZ E4b (Kristensen et al., 2000), consistently to the NW Danish marine records (Seidenkrantz 1993, Larsen et al., 2009). The Baltic Sea basin during the LIG has also connected to the White Sea over nowadays NW Russian (Ladoga lake; Karelia), the timing of which is independent (Funder et al., 2002) from the events and foraminiferal, boreal and Lusitanian mollusc evidence connecting the Cyprina Clay to North Sea incursions.

Regression along the SW Baltic is not well vertically resolved, as would-be littoral sequence there experienced subsequent subglacial erosion by the Scandinavian ice-sheet expanding across it during the Last Glacial, and deglacial fluvial erosion and reworking (Meng et al., 2021). In the deeper water paleogeographic setting on the Danish side, the Baltic is marine well into the Early Weichselian, owing to its deep N-S connections to Kattegat and Skagerrak. The secondary connection W-E 
https://doi.org/10.5194/essd-2021-390

Preprint. Discussion started: 10 November 2021

(c) Author(s) 2021. CC BY 4.0 License.

(c) (i)

across Schleswig (Fig. 1) is considered to have fallen dry early on in PAZ E6, as site Schnittlohe then shows a return to limnic conditions (section 2.3). Limnic and peatland deposits replaced littoral environments at the end of the interglacial (PAZ E5/6 transition) also in Baltic Sea palaeobays in NE Germany (Meng et al., 2021), but the evidence for this is from

315 displaced and reworked contexts and no sites have provided opportunity of water level reconstructions. East of the area covered in this paper, terrestrial deposits topping estuarine ones in the Vistula (Wisla, Weichsel) valley sequence give similar indication (site Nowiny, Poland; Makowska 1986 op cit. Funder et al., 2002; Drozowksi, 1988 op cit. Lambeck et al., 2006).

\subsection{North Sea: Thames Estuary, East Anglia, North England}

The stratigraphy of the Thames region of eastern England has been extensively studied and documented from the $19^{\text {th }}$ century as the development of London and the surrounding area exposed multiple phases of cold-riverine and warm organic interglacial sediments, many with marine and freshwater micro and macro-fossils. The discovery of Eemian Hippopotamus remains during excavations of Trafalgar Square in the 1950's (Franks, 1960) garners continued wider attention; but numerous less publicised investigations have identified previous interglacial brackish, coastal and shallow marine sediments (e.g., Abbott, 1892; Gibbard, 1985; Preece, 1999; Sparks and West, 1963; Hinton and Kennard, 1901). Similarly in East

325 Anglia, local site investigations document the presence of brackish or marine molluscs at several sites corresponding to the 'Ipswichian' (Eemian) interglacial based upon pollen stratigraphy, for example at March (Whitaker et al., 1893) and Wretton (Sparks and West, 1970). Further north, evidence of LIG sea level is sparser with much of it removed by the subsequent Last Glacial (Devensian) ice advance along the coast of North East England and Yorkshire (Sutherland et al., 2020; Catt, 2007), and is largely restricted to the Sewerby raised beach, East Yorkshire (Bateman and Catt, 1996; Lamplugh, 1887; Catt and Penny, 1966), which is now buried under a landslide.

A major challenge is that interglacial sites from England, unlike in the Dutch-German-Danish contexts where Saalian glaciogenic landforms and substrates allow to separate LIG from older interglacial sites, often appear in ambiguous stratigraphic positions. Whereas palynologically and using molluscan assemblages they can be identified to be from warm periods and near-coastal environments, the sites lack independent dating, and pollen sub-stages of the 'Ipswichian' and the preceding 'Hoxnian' interglacials have very similar vegetation profiles (Thomas, 2001; Turner and West, 1968). Attempts to correlate seven, then termed, 'Ipswichian' estuarine sequences from the Thames, alongside those from East Anglia, based upon pollen sub-stages and their relative elevations, resulted in a paper by Hollin (1977) on Ipswichian sea levels and Antarctic ice surges identifying the potential for a double LIG sea-level highstand, investigating the idea of a late, rapid collapse of the Antarctic ice sheet. Though in keeping with more recent hypotheses (e.g., O'Leary et al., 2013), significant advances in AAR methods (in particular dating freshwater Bithynia tentaculata opercula (Penkman et al., 2013)), combined with Thames terrace stratigraphy (Bridgland, 1994), vertebrate and molluscan biostratigraphy (Schreve, 2001; e.g., Preece, 2001) and independent geochronology (e.g., OSL) has since shown that many British 'Ipswichian' sites actually date from the preceding three marine isotope stages (Penkman et al., 2011; 2013; Penkman et al., 2008). Trafalgar Square is the only 
https://doi.org/10.5194/essd-2021-390

Preprint. Discussion started: 10 November 2021

(c) Author(s) 2021. CC BY 4.0 License.

(c) (i)

345 site in Hollin's (1977) analysis which is still regarded of LIG age. Ilford, Aveley and Crayford are now known to have been deposited during MIS 7; Purfleet and West Thurrock during MIS 9; and Little Thurrock in MIS 11 (Penkman et al., 2011; Penkman et al., 2008). Likewise the Speeton Shell Bed in East Yorkshire (Lamplugh, 1881; West, 1969) is now thought to date to MIS 7 (Wilson, 1991).

\subsection{English Channel: Southern England}

350 LIG deposits are found along the length of the southern coastline of Britain, typically as part of expansive sequences of raised littoral terraces from the Pleistocene. Occurrences of Pleistocene deposits that formed during interglacials are well documented across all southern coastal counties (Prestwich 1892) in early literature; from Kent in the south east (Mackie 1851), through Sussex (Godwin-Austen 1857; Prestwich, 1859; Reid 1892), Hampshire (Reid 1893) and Dorset (Weston 1852; Prestwich 1875), to Devon and Cornwall (De La Beche 1839, Ussher 1879) in the southwest. Pleistocene littoral deposits occur around Land's End (the southernmost point of mainland Britain) and can be found on the northern coastlines of Cornwall and Devon, the east coast of Somerset (Woodward 1876) and from there across the southern coastline of South Wales (Murchison 1868; Prestwich 1892). Unsurprisingly, the early literature associated with these widespread deposits extends to include raised littoral deposits on the main island groups in the English Channel: the Isle of Wight (GodwinAusten 1855, Prestwich 1859), the Isles of Scilly (Barrow 1906), and the Channel Islands (Zeuner 1946).

Early literature typically relied on the identification of mammalian and molluscan fauna, as well as pollen assemblages and successions, to attribute deposits to successive interglacials. The elevations of littoral terraces (typically, raised beach deposits) and apparent positions in flights of these were also used. The relative elevations of deposits also became a useful tool for tracking contemporaneous raised littoral terraces across wider geographical areas (Palmer and Cooke 1923; Arkell

365 1943; Mitchell 1960; Orme 1960; West and Sparks 1960; Hodgson 1964). A commonality that emerged was that the Ipswichian (Eemian/MIS 5e) interglacial was likely associated with the lowest terrace of deposits, often reported as a " 15 foot raised beach' (c. 4.5 m O.D.) (Fig. 3a). However, association with the preceding interglacial (MIS 7) was hard to rule out, especially given the presence of multiple, distinguishable low-level raised beach deposits at several locations (Davies and Keen 1985; Mottershead et al., 1987; Bates et al., 1997). Dating attempts often remained inconclusive and debated (Mitchell 1972; Bowen 1973). Unfortunately, despite the development and application of novel quantitative dating approaches during and since the 1980s, many low-level raised littoral deposits in southern and southwest Britain still lack confident and precise age determinations (see further discussion in section 6). 

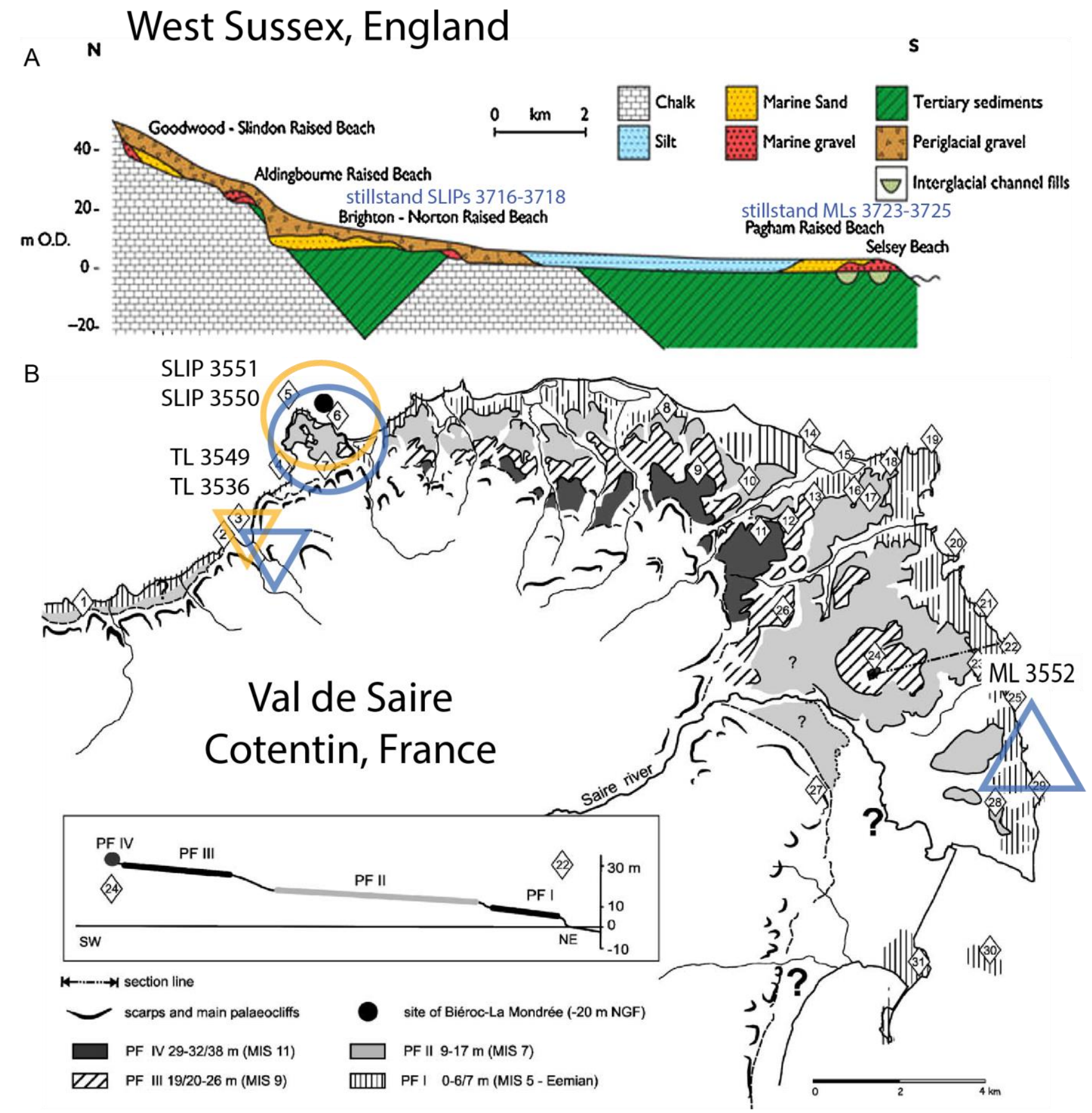

Figure 3 Selected figures illustrating research history and database contents for South England (panel A) and Northwest France (panel B), with annotations (database IDs, grouping in transgression, stillstand, highstand). A) Schematic section of raised beach series (Bates et al., 2010), with SLIP producing and ML producing sites annotated. B) Wave-cut platforms (PFs) as mapped for NE Cotentin (Coutard et al., 2006), annotated with LIG SLIPs, MLs and TL locations, associated to the PF I level. Panels reproduced with permission (A, B: Elsevier). 
https://doi.org/10.5194/essd-2021-390

Preprint. Discussion started: 10 November 2021

(c) Author(s) 2021. CC BY 4.0 License.

(c) (i)

\subsection{English Channel: Northwest France}

380 The northwest coast of France, from Britany to the Straits of Dover, is characterised by the occurrence of a staircase of polygenic coastal platforms that were correlated with Pleistocene interglacial periods. These platforms are intermittently covered by a variety of coastal (mainly raised beaches) and periglacial deposits (heads and loess) that have been studied for more than a century (Barrois, 1877, 1882; Bigot, 1885, 1930; Guilcher, 1948; Pellerin and Dupeuble, 1979; Lautridou et al., 1999; Regnauld et al., 2003; Coutard et al., 2005, 2006; Cliquet et al., 2009; Pedoja et al., 2018). The absence of wellpreserved fossiliferous remains in most of these sites gave rise to an extensive discussion about their chronostratigraphy, and the age was generally established based on the altitude of the beach deposits relative to other sites. In the Armorican Massif, two levels of marine deposits, between 0-5 and 15-20 m above sea level were attributed to the LIG (Elhaï, 1963), while Morzadec-Kerfourn and Monnier (1982) attributed the three lower levels, found between 0-15 m in Britany, to three distinct marine transgressions, probably MIS 9 to MIS 5.

The discovery and excavation of Palaeolithic sites along the coast and the progressive application of thermoluminescence (TL), optically stimulated luminescence (OSL) and electro spin resonance (ESR) geochronology (e.g., Balescu et al., 1991; Balescu and Lamothe, 1992; Loyer et al., 1995; Folz, 2000; Coutard et al, 2006; Cliquet et al., 2003, 2009; Monier et al., 2011) boosted the understanding of the coastal sequences and helped to better constraint the distribution of the LIG deposits.

395 Loyer et al., (1995) suggested that up to four different interglacials were preserved in the same coastal platform in SaintBrieuc Bay (Britany) based on palaeoenvironmental data and TL dating of loess deposits, later further supported by ESR dating of Palaeolithic sites (Bahain et al., 2012). Thermoluminescence dating of burnt flints in Port-Racine (Normandy), attribute beach deposits at $3 \mathrm{~m}$ to the Eemian (Cliquet, 1992, Lautridou et al., 1999), and Coutard et al., (2006) OSL dated several marine, beach and dune deposits in Val de Saire (Normandy; Fig. 3b) pointing to the MIS 5e to 5d. Despite the

400 fragmentary nature of the deposits and the relatively small number of absolute age determinations, there were also some attempts to reconstruct the LIG coastline in Normandy (Regnauld et al., 2003) and to establish regional stratigraphic correlations across the English Channel (van Vliet-Lanoë et al., 2000; Bates et al., 2003). Deposits corresponding to the LIG appear better preserved in Britany and western Normandy (Fig 3b) where the local geomorphology protected these sediments from later erosion; however, further east Pleistocene beach deposits were eroded in younger interglacials and the Holocene 405 (van Vliet-Lanoë et al., 2000; Bates et al., 2003; Regnauld et al., 2003). As an exception, at Sangatte in NW France a cliff foot beach (De Heinzelin, 1966) that predates the LIG (Balescu and Haesaerts, 1984; Haesaerts and Dupuis, 1986; Balescu et al., 1991) is preserved under colluvium, re-exposed by Holocene erosion. 
https://doi.org/10.5194/essd-2021-390

Preprint. Discussion started: 10 November 2021

(c) Author(s) 2021. CC BY 4.0 License.

(c) (i)

\section{Sea level indicators}

\subsection{Regional context differences}

On identifying and describing LIG depositional settings and interpreting relevance for sea-level reconstructions, comparison is often made to the modern setting. Figure 1 is an overview map depicting the approximate LIG coastline relative to current topography, while Table 2 lists the coastal settings region-by-region. Considerable spatial variation exist is the current coastline around the North Sea and English Channel, as did during the LIG highstand. Extensive lowland coastal plains with back-barrier tidal environments, marshes and lagoons dominate the NW Belgian-Dutch-German-SW Danish stretch of North

415 Sea coast, interrupted by headlands of Saalian age ice-marginal morphology (push moraine-outwash complexes, till sheet plateaus) and merging with estuaries and delta plains of main rivers (Elbe, Weser, Ems, Rhine, Meuse, Scheldt). The English side of the North Sea coast has cliffs in Middle Pleistocene till accumulations over Chalk bedrock at shallow depth along Lincolnshire and East Anglia, a series of smaller estuaries interrupted by Paleogene outcrops in Suffolk, opening into the Lower Thames estuary which reaches inland to central London. Chalk cliff interrupted by estuaries such as the Medway form the coast of Kent and the Strait of Dover. This marine reach connecting North Sea and English Channel is not a regular shelf area, but a transgressed, eroded gorge created by lowstand periglacial and proglacial outwash rivers (repeatedly since the Middle Pleistocene) (Gibbard, 1995; Bridgland and D’Olier, 1995; Gupta et al., 2007; Mellett et al., 2013). The British and French coasts on either side of the English Channel alternate inset estuaries (larger ones named in Fig. 1) with cliff and bluff sections (with gravelly to sandy beaches at their feet), in a variety of substrates (Mesozoic, Palaeozoic, crystalline). Bedrock island features such as the Isle of Wight (British side), Channel Islands (French side) and Belle Isle (SW Brittany) existed in LIG and Holocene times alike.

When comparison is sought between the current and previous highstand, the geomorphological age and longevity of landforms that constrain the coastline must be considered, especially in the North Sea region with its intermittent glaciations (Cohen et al., 2014; Cohen, 2017). Whereas the broad position of estuaries and cliff-beach settings along the English Channel and in the SW of the North Sea is essentially the same between the LIG and Holocene, the configuration of lagoons, river mouths and morainic islands in the Netherlands and the German Bight sectors of the North Sea (the area between Saalian maximum and Last Glacial limits in Figure 1) is fairly different. In this eastern North Sea region, the Eemian transgression and highstand affected a paraglacial landscape left after the Saalian deglaciation (Table 2). Furthermore, the long-term basin subsidence (depocenter indicated in Fig. 1) have made Eemian paleo-coastal depositional architectures preserve as subcrop: highstand sea-level encountered at several meters below the equivalent modern sea-level position. This affects the way deposits are studied (e.g., boreholes v. outcrops) and the areal extent over which deposits tend to preserved (extensive basin-central patches, v. small pockets at the rims of a system). By comparison, western North Sea LIG features along the coast of the UK and France are preserved at higher elevations due to the relative lack of long-term subsidence. 
https://doi.org/10.5194/essd-2021-390

Preprint. Discussion started: 10 November 2021

(c) Author(s) 2021. CC BY 4.0 License.

\subsection{Overview of Indicator Types}

Table 3 presents an overview of the indicator types associated to the SLIPs, including regional statistics. In the WALIS database structure, terrestrial and marine limiting data entries are not further specified to type. Formal descriptions are provided for each indicator type. All indicator types have Holocene analogue environments in the same region. Most indicator types constrain RSL elevations by combining sedimentary properties, fossil content, and architectural evidence. In all cases, marine biota supported choices of specific Indicator Types. We used (in part: defined) 10 types of RSL indicator in this region (Table 3), and document the non-generic ones below.

Table 3: Types of RSL indicators used in NW Europe database.

\begin{tabular}{l|l|l|}
\hline Name of RSL indicator & Indicator reference(s) & $\begin{array}{c}\text { ID in Region and } \\
\text { WALIS \# of occurrences }\end{array}$ \\
\hline
\end{tabular}

WALIS generic, not further documented here - see other papers ESSD special issue

$\begin{array}{llcl}\text { Marine Terrace } & \begin{array}{l}\text { Pirazzoli, 2005 } \\ \text { Pedoja et al., 2011 } \\ \text { Rovere et al., 2016 }\end{array} & 7 & \text { France (12 LIG, 3 older) } \\ \text { Beach deposit or beach rock } & \begin{array}{l}\text { Mauz et al., 2015 } \\ \text { Rovere et al., 2016 }\end{array} & 11 & \begin{array}{l}\text { France (7 LIG, 5 older) } \\ \text { United Kingdom (4 LIG, 9 older) }\end{array} \\ \begin{array}{l}\text { Beach ridge; } \\ \text { Beach swash deposit }\end{array} & \begin{array}{l}\text { Otvos, 2000 } \\ \text { Rovere et al., 2016 }\end{array} & 12, & \begin{array}{l}\text { France (1) } \\ \text { United Kingdom (2 LIG, 1 older) }\end{array} \\ \text { Lagoonal deposit } & \begin{array}{l}\text { Rovere et al., 2016 } \\ \text { Zecchin et al., 2004 }\end{array} & 15 & \text { Netherlands (3 LIG, 1 older) }\end{array}$

Paper Author added as part of this study, documented by sections 3.2.1 to 3.2.5.

Drowned valley floor Transgressive Contact

Basal Peat (non-mangrove)

Isolation Basin (moment of marine connection)
Vis et al., 2015

Peeters et al., 2016, 2019

Jelgersma, 1960

Van de Plassche, 1982

Zagwijn, 1983

Hijma and Cohen, 2019

Zagwijn, 1983

Van Leeuwen et al., 2000

Beets et al., 2006
17

Netherlands (1)

Denmark (1)

$18 \quad$ Netherlands (3)

Denmark (2)

19 Netherlands (3) 
Estuarine Terrace (preserved tidal flat surface)

Salt marsh

(various subtypes)

WALIS generic, but region specific information provided in section 3.2.6

Shallow or intertidal marine fauna
Subregion specific

Refs in section 3.10
De Moor and De Breuck, 1973

Zagwijn, 1983

Peeters et al., 2016, 2019
37 United Kingdom (2)
Belgium (9 LIG, 1 older)

Germany (3)

Netherlands (2 LIG, 1 older)

Englehart and Horton, 2012

\subsubsection{Indicator type: Drowned Valley Floor}

This indicator type relates to a contact between terrestrial depositional facies (below) and subaquatic depositional facies (above) and provides transgressive context SLIPs. The terrestrial facies is typically a decimetre thick river organic mud with immature palaeosol, if not a flood-basin peat bed, with further fluvial facies below [late lowstand palaeosols, evidence of climatic amelioration before transgression]. The subaquatic facies is typically a decimetre-metre-thick organic mud, rich in

fine and coarse detrital organic matter, rich in silt admixture, bearing tidal indicators, bearing microfossil indicators of occasional brackish estuarine in wash. It grades upward into established tidal, brackish to saline, full estuarine facies. See Hijma and Cohen $(2011,2019)$ for Holocene examples and Sier et al. (2015) and Peeters et al. $(2016,2019)$ for LIG examples.

460 The transgressive contact has direct meaning as to estuarine inundation, and represents the SLIP. The secondary contact within the terrestrial facies can be used as a terrestrial limiting point. In wide valleys experiencing relatively rapid postglacial transgression, unfilled estuaries result in which tidal amplification (owing to estuary funnelling) is not yet a major factor (HAT values may in fact be dampened inland in such estuaries). Herein the estuary in a freshly drowned lowland valley differs from later stages of estuary development as observed in highstand filled estuaries (inland propagation, amplification and dissipation does affect estuarine type SLIPs). On the other hand, in inland parts of the estuary riverine discharge may impose a gradient and lift dampened inland tides to the same altitudes as that of HAT at the estuary mouth (Van de Plassche, 1995; Vis et al., 2015). For these reasons, the 'Drowned Valley Floor' base-estuarine indicator type is kept separate from the 'Basal Peat' and 'Estuary terrace' indicator types that are introduced below.

470 In formula (HAT $=$ Highest Astronomical Tide; MSL is mean sea-level, a.k.a. half tide):

WALIS Relative Water Level description: (HAT to MSL) / 2

WALIS Indicative Range description: HAT to MSL 
https://doi.org/10.5194/essd-2021-390

Preprint. Discussion started: 10 November 2021

(c) Author(s) 2021. CC BY 4.0 License.

(c) (i)

\subsubsection{Indicator type: Basal Peats}

Basal Peats are terrestrial deposits encountered along the base of transgressive-to-highstand depositional systems and in submerged position on inner shelves (e.g. Jelgersma, 1979; Hanebuth et al., 2000). Using basal peats as RSL indicators became widely established in Holocene sea-level communities since the 1970s (Van de Plassche, 1986), both onshore and offshore. Jelgersma (1961) and Van de Plassche (1982, 1995) provide classic Holocene reference examples for The Netherlands. Likewise, it is useful as an RSL indicator in interglacial coastal settings (e.g. Zagwijn, 1983; Streif, 1990, 2004; Konradi et al., 2005), especially when combined with palynological investigations to provide time-control on the position within the interglacial (see section 3.3).

Basal peats are found underneath transgressive surfaces, buried by subaqueous deposits. Basal peats occur across valley floors, across valley rims, across interfluve highs, across flanks of isolated topographic features within older coastal marsh and subaquatic aggradational facies (above). The peaty terrestrial facies is typically a few decimeters thick (in compacted state, cf. Greensmith and Tucker, 1986; Brain, 2015), and often overlies a surface with a more developed paleosol. The latter are 'late lowstand' boreal to temperate paleosols, which indicate that notable climatic amelioration occurred before actual transgression, i.e. a time gap between climatic onset of interglacial and establishment of the highstand.

The very top of a Basal Peat bed indicates submergence of a swamp/marsh and may be recorded as a SLIP. The very base of

Basal Peat bed indicates a palaeo-groundwater level (GWL) that in sea-level reconstruction context becomes a terrestrial limiting point. In argued cases such a limiting point may be upgraded to a SLIP, if it formed along the inland rim of a transgressive lagoonal or lagoonal-deltaic environment (e.g. Van de Plassche, 1986; Nelson, 2015). Assessing the palaeogeographical situation of the basal peat data point, or swarm of data points, may help to screen limiting points and upgrade the status of coastally most-relevant ones (Vis et al., 2015; Hijma and Cohen, 2019).

495 In formula:

WALIS Relative Water Level description: GWL

WALIS Indicative Range description: Swamp peat: (GWL to GWL-0.2m); Marsh peat (GWL-0.3 to GWL-0.8m).

\subsubsection{Indicator type: Isolation Basin (marine connection moment)}

Isolation basins are used extensively in Holocene sea-level studies in higher latitude coastal environments, making use of the prominent occurrence of lakes in freshly deglaciated environments, and the ecological sensitivity of such water bodies when connecting and disconnecting from the sea (e.g., Long et al., 2011; Shennan et al., 2005; Sundelin, 1917). In the North Sea area, substantial lakes formed when ice sheet cover from the penultimate glaciation disintegrated (during MIS 6). The period at which these lakes connected to the North Sea and transformed into highstand marine embayments, has been a primary constraint on the relative timing of the Eemian Transgression (e.g. Zagwijn, 1983). The reconstructed elevation of lake sills 
https://doi.org/10.5194/essd-2021-390

Preprint. Discussion started: 10 November 2021

(c) Author(s) 2021. CC BY 4.0 License.

(c) (i)

505 (the lowest point of the basin rim) provides the elevation of SLIP of this type, whereas the contact between lacustrine environment (lower) and brackish-marine environment (upper) established in central part of a basin is the location where age control is obtained. Ideally the sill of an isolation basin is formed of unmodified bedrock (Long et al., 2011), whereas the lake shorelines in the North Sea are formed of glacial diamicton and/or glaciotectonised ridges (Zagwijn, 1983; De Gans et al., 2000), which means additional uncertainty as to their elevation must be given. Our WALIS database entries have registered the latter location as coordinates. The site description mentions separately where the paired sill level is positioned. Relative Water level description and IR link to the sill location. Water depth of the lake is irrelevant for the application. In formula:

\section{WALIS Relative Water Level description: (HAT to MSL)/2}

WALIS Indicative Range description: $\quad$ (HAT to MSL) + uncertainty sill level position

\section{3.2.4 Indicator type: Estuarine Terrace}

This indicator type is introduced as a variant of the Marine Terrace (cf. Pirazzoli et al., 2005) as used elsewhere in the WALIS database. Paraphrasing that description, it considers "any relatively flat surface of estuarine origin". A difference with the Marine Terraces is that the orientation of the estuarine terrace is 'along' a falling-stage river valley / highstand embayment, and 'across' the shoreline of headland coasts and barrier-coastal stretches. Furthermore, the 'flatness' of the abandoned surface is not so much due to wave action and storm swash, but more due to intertidal/supratidal flooding just prior to terrace abandonment. Estuarine terraces provide indicators for highstand and regressive contexts mainly. In landward direction, estuarine terraces grade to riverine terraces / former floodplains that provide terrestrial limiting point rather than SLIPs. The Estuarine Terrace indicator type is introduced next to Marine Terraces, to allow to assign different indicative meaning to elevations sampled from estuarine terraces where the 'flat' surfaces are usually formed in facies bearing intertidal sedimentological indications (alluvial terraces), than to marine terraces that are flattened due to abrasion processes (straths). Site Balgerhoeke (Heyse, 1979; IDs 339, 340; Scheldt) and site Petten (Zagwijn, 1983; ID 146; Rhine) provide for highstand and regressive SLIP examples (see Figs. 1 and 2).

In formula:

WALIS Relative Water Level description: (HAT + MSL) / 2

WALIS Indicative Range description: Between MSL and HAT (upper intertidal)

\subsubsection{Indicator Types: Salt marsh (various subtypes)}

Salt marshes have been used extensively in Holocene sea level research, as their elevation and position is directly controlled by the tidal elevation and therefore can be directly related to a reference water level (Engelhart and Horton, 2012; Shennan et al., 2018; Barlow et al., 2013). The indicator type differ from 'basal peat' and 'estuarine tidal flat' types, because study of 535 microfossils allowed to identify it as a coastal salt marsh specifically. The identification of palaeo salt marsh is usually through the identification of salt marsh specific taxa such as the pollen of Plantago maritima and Triglochin (Gehrels, 1994); 
https://doi.org/10.5194/essd-2021-390

Preprint. Discussion started: 10 November 2021

(c) Author(s) 2021. CC BY 4.0 License.

(c) (i)

the presence of salt marsh foraminifera such as Jadammina macrescens, Miliammina fusca and Trochammina inflata (Gehrels, 2000; Edwards and Horton, 2000); and brackish water diatoms and ostracods (Penney, 1987; Barlow et al., 2013; Zong and Horton, 1998). Such microfossils cover a limited elevation range from HAT to MSL and hence make the salt marsh provide an excellent sea-level index point. Where sedimentation could keep up with the rate of RSL change, salt marsh may be preserved at the transgressive or regressive boundaries often between freshwater peats and estuarine silts and clays. Microfossil sampling resolution is often coarse in LIG estuarine sediments $(>5-10 \mathrm{~cm}$ intervals) and coastal salt marsh deposits may be missed between samples. Therefore, there are only two explicit occurrences in the LIG salt marsh SLIPs within the NW European database. A number of sites classified as 'basal peats' may well be overlain by fine grained marine sediments that could be salt marsh. Also several 'estuarine terrace tidal flats' sites are reported to have been overlain by salt marsh muds and peats (e.g. Balgerhoeke, Belgium, IDs 339 and 340; Land Hadeln, Germany. IDs 882 and 883). Revisiting sites of these type may present opportunities to narrow down the indicative range of some SLIPs. In formula:

WALIS Relative Water Level description: (HAT to MSL)/2

WALIS Indicative Range description: Highest astronomical tide - mean tide (or sea) level

\subsubsection{Indicator Type: Shallow or intertidal marine fauna}

This generic SLIP indicator type entry in WALIS considers palaeobiological identified marine fauna that can be associated with very shallow water and/or intertidal environments, especially where fossilized 'in viva'. It was used when sedimentary, morphological identifiers are not available, and where sites did not convincingly fall in one of the categories listed above. In the North Sea, macroscopically, usually these are the shells of intertidal mollusca. In Danish contexts, also foraminifera assemblages have been used as water depth and current regime biotic indicators in Eemian shallow marine beds (e.g. Konradi 1976, Konradi et al., 2005), as are diatom assemblages (e.g. Van Leeuwen et al., 2000; Beets et al., 2008). Most commonly, though, it is the macroscopically spotted shells of molluscan fauna that are used. Cerastoderma edule (also known as Cardium) and Scrobicularia plana are very common intertidal species in the North Sea, in Holocene and LIG deposits alike. Macoma Baltica and Spisula truncata are also frequently encountered (and used for AAR characterisation; Miller and Mangerud 1986, Meijer and Cleveringa, 2009, Demarchi et al., 2011). In deeper waters of the offshore North Sea, Skagerrak and SW Baltic, the common species are Arctica islandica (also known as Cyprina) and Turritella communis. In the English Channel, foraminifera Elphidium sp. and Ammonia sp. are common intertidal indicators (e.g., Bates, 2010). Some of these species ('Lusitanian components') in the LIG extended their common presence into North Sea and SW Baltic too (e.g. Madsen et al., 1908; Miller and Mangerud, 1986; Funder et al., 2002; Meng et al., 2021), whereas in the Holocene they did not (or to a far more limited extent). Examples are Venerupus senescens (Tapes aurea (var. eemensis), Paphia aurea, Amygdala), Bittium sp., Cardium exiguum. Nolf (1973), Miller and Mangerud (1986: their part II), Meijer and Preece (1995), Wesselingh et al. (2010), Meijer et al. (2021) are illustrative biota-oriented papers on this. This means that literaturereported molluscan faunas hold both 'vertical' indicative meaning, as well as 'age' chronostratigraphic meaning. 
https://doi.org/10.5194/essd-2021-390

Preprint. Discussion started: 10 November 2021

(c) Author(s) 2021. CC BY 4.0 License.

(c) (i)

In formula:

WALIS Relative Water Level description: Based on the upper and lower limits of living modern analogue faunas

WALIS Indicative Range description: Based on the upper and lower limits of living modern analogue faunas

\subsection{Chronostratigraphical entries}

The Dutch, Belgian, German and Danish sites are primarily studied through pollen-zone biostratigraphy, which is also used as relative dating information (e.g. Lambeck et al., 2006; Kopp et al., 2009: "relative ages are known with more precision than absolute ones"). Hence, in the WALIS database, we defined 'chronostratigraphic method' standardized entries (Table 4) to encode this form of dating control, and used these for the Netherlands', Belgian and German Bight sites. The standard entries refer to the six main pollen zones of the Zagwijn (1996) floating scheme, and the descriptions include the correlated schemes of Zagwijn (1961, 1996) for the Netherlands; Behre (1962), Selle (1962), Müller (1974) and Menke and Tynne 580 (1984) for NW Germany; Jessen and Millers (1928) in Denmark and NW Germany; and further discussions in Benda and Schneekloth (1965), Grüger (1989), Zagwijn (1969), and Funder et al. (2002). Abundant literature and ongoing debate exist regarding absolute timing of onset of the LIG and degree of diachronicity within and between the regional schemes, their correlation with Southern Europe counterparts, and (non-)analogy with the Lateglacial-Holocene (e.g., Van Leeuwen et al., 2000; Cleveringa et al., 2000; Turner, 2002; Kukla et al., 2002; Beets and Beets, 2003; Beets et al., 2006; Lambeck et al., 585 2006; Sier et al., 2015; Long et al., 2015).

To make database usage not too dependent on shifts and positions in debates on timing and duration of the NW European Eemian (covered in Section 6.1), the design of the 'Dated By: Chronostratigraphy' entries (Rovere et al., 2020) requires filling four duration and timing database fields. Two of these deal with the palynological correlation and varve-counting 590 locally established durations and its uncertainty (Müller, 1974; Zagwijn, 1996 - see Table 4 footer). Two further fields store a lower and upper limiting numeric age. The first one bounds the onset of the interval (oldest moment the zone may have begun), the second one the ending (latest moment represented in the zone). For a fictive zone with a duration of 4000 years that could be perfectly pinpointed in time, lower and upper limit would be 4 ka apart. For a floating chronology such as the set of zones used in the North Sea region, the limits are some $10 \mathrm{ka}$ apart (e.g. the PAZ E5 and E6 rows in Table 4), the

595 difference being the $6 \mathrm{kyr}$ difference entertained for the onset of the Eemian in the literature of the last 20 years (see Long et al., 2015 for summary). Entries were made for 23 LIG chronostratigraphic divisions (Table 4). 18 of them dealing with terrestrial palynological subdivisions (see Table 4 footer); 5 dealing with SW Baltic and Kattegat-Skagerrak marine environmental phases (Cyprina clay phases of Kristensen et al., 2000; Funder et al., 2002; Kattegat stadial of Seidenkranz, 1993), that in turn were correlated and connected to the terrestrial schemes. A meta-field storing parent-child relationships

600 for chronostratigraphic division was also maintained. Comprehensive explanatory text, referencing positions taken in literature, fills the note field for the parent entries and provide a rationale for the lower and upper numeric ages provided. 
Table 4: 'Dated by: Chronostratigraphy' entries for North Sea, Skagerrak-Kattegat and SW Baltic Sea

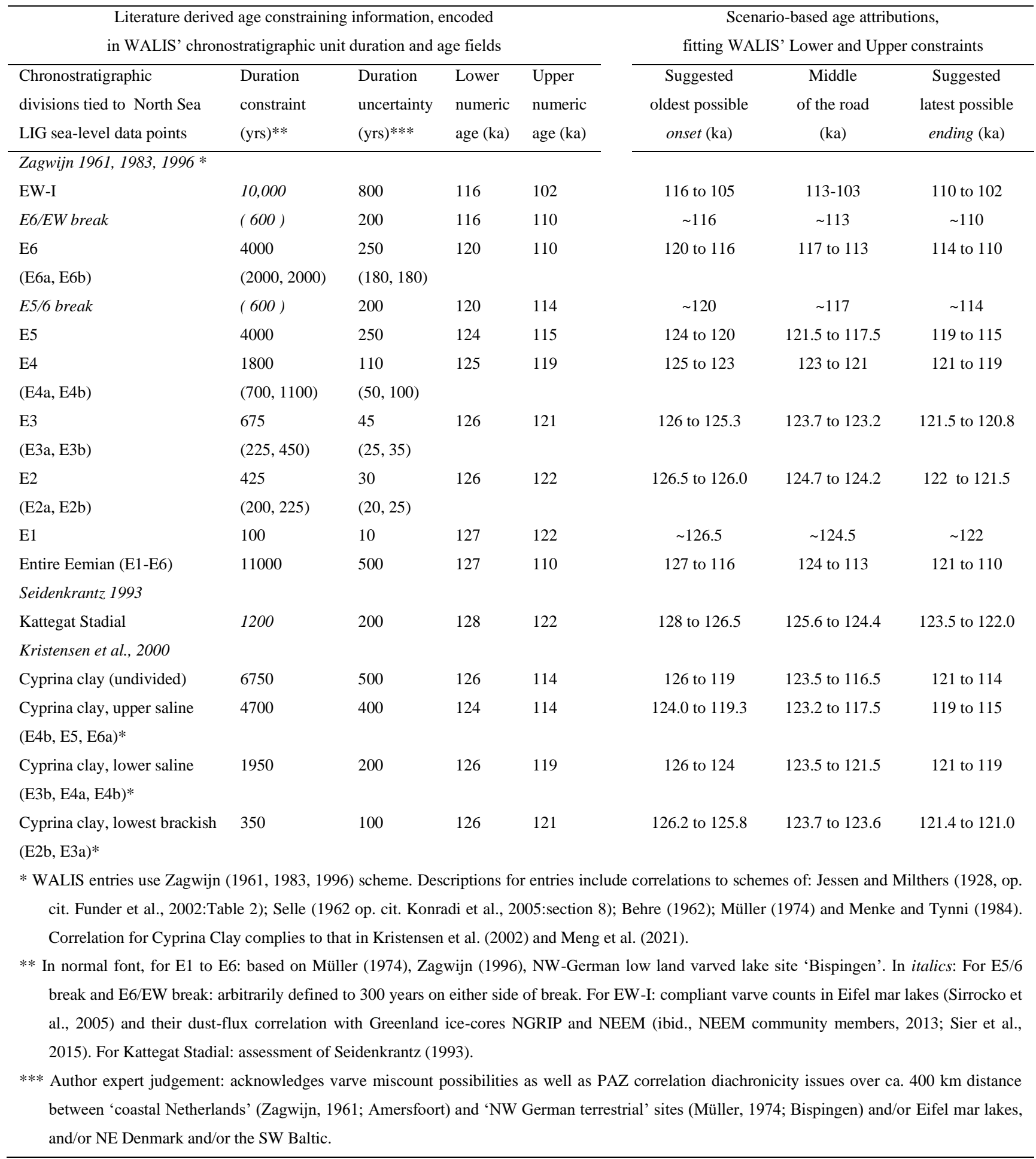


https://doi.org/10.5194/essd-2021-390

Preprint. Discussion started: 10 November 2021

(c) Author(s) 2021. CC BY 4.0 License.

(c) (i)

605 Section 6.1 includes reasoning and reference on why to enter $127 \mathrm{kyr}$ (a few 1000 years into MIS5e) as the oldest advised onset age for NW European Eemian pollen zones, and not $130 \mathrm{kyr}$ (midpoint Termination II in marine oxygen isotope stacks). The geochronological user of the database may want to extract PAZ durations and suggested age-midpoints from WALIS (its equivalent of Table 4), formulate some rules that make sure that PAZ order and cumulative duration remain honoured while shifting the PAZ-series to earlier or later moments in time (e.g. Bronk-Ramsey, 2008), and then invoke

610 Bayesian age-modelling approaches to explore what amount and direction of shift best to minimizes differences with sites with numerical age control. This is a challenge, however, because the absolute dating techniques may themselves be subtly biased, to older or younger side. Ideally, a regional Bayesian calibration approach combines the optimizations for in the vertical (RSL) and temporal (age) directions (e.g. Hijma and Cohen, 2019). The NW Europe database and that of WALIS more broadly may inspire such work for the LIG (Düsterhus et al., 2016).

615

We stress that the numeric ages and durations advised are for the North Sea region mainly. Site Bispingen where the Müller1974 varve-counts come from (Fig. 1), lies within $100 \mathrm{~km}$ of sites in the German Bight and within $500 \mathrm{~km}$ of the Belgian sites where in our dataset the scheme was applied furthest away. If WALIS entries for RSL indicators with palynologyderived chronostratigraphic age control are needed for sites further east (e.g. where the Russian 'Mikulinian' zonation

620 schemes are used) or to the southwest in the English Channel (see next section), we advise to make new separate entries in WALIS, allowing to adapt advised oldest and youngest age bounds, and stimulating users to explore possible W-E diachronicities.

\section{Elevation measurements and corrections}

\subsection{Present elevation, national datums}

625 The measurement elevations for the studied sites been reported in various forms (Table 5). Our approach has been to express data points as much as possible to Datums relating to $19 / 20^{\text {th }}$ century reference mean sea level (Table 6), applying conversions when needed. Hereto, we checked and registered against which datum the elevations were expressed in original studies (for further dicussion see Woodroffe and Barlow, 2015). Some countries in the study area use a national datum that approximates modern mean sea level elevation (e.g. Netherlands: NAP, German: NHN and NN, Danish: DNN and DVR90;

630 e.g. Wiśniewski et al., 2014). In these cases we express the elevations against national datum (typical entries then reproduce originally reported values). Other countries use a national datum that approximates low mean springtide / lowest astronomical tide (e.g. Belgium: TAW and UK: regional Chart Datums). Being larger countries, the relationship between the national datums in the British Isles and France (e.g., the UK's Ordnance Datum, OD) and low tide and mean sea-level is geographically more variable (Bradshaw et al., 2016; Bradley et al., 2011). For Belgium, the approach has been to subtract

$6352.33 \mathrm{~m}$ from reported elevations expressed to TAW datum (Table 6) to express elevations to a MSL based datum, as in surrounding countries. 
Table 5: Measurement techniques used to establish the present elevation of Last Interglacial Sea-level data points

\begin{tabular}{|c|c|c|}
\hline $\begin{array}{l}\text { Measurement } \\
\text { technique }\end{array}$ & Description & Typical accuracy \\
\hline $\begin{array}{l}\text { Cross-section } \\
\text { from publication }\end{array}$ & $\begin{array}{l}\text { The elevation was extracted from a published } \\
\text { sketch/topographic section. }\end{array}$ & $\begin{array}{l}\text { Variable, depending on the scale of the } \\
\text { sketch or topographic section. }\end{array}$ \\
\hline $\begin{array}{l}\text { Differential GPS } \\
\text { (DGPS) }\end{array}$ & $\begin{array}{l}\text { Positions acquired in the field by 'rover' GPS } \\
\text { stations, corrected either in real time or during } \\
\text { post-processing with respect to the known } \\
\text { position of a 'base' GPS station (or a geostatio- } \\
\text { nary satellite system). DGPS accuracy depends } \\
\text { on distance from base station, and number of } \\
\text { static positions acquired per location. }\end{array}$ & $\begin{array}{l} \pm 0.02 / \pm 0.08 \mathrm{~m} \text {, depending on survey } \\
\text { conditions (e.g. satellite reception) and } \\
\text { instruments used (e.g., single-band vs dual- } \\
\text { band receivers) }\end{array}$ \\
\hline $\begin{array}{l}\text { Metered tape or } \\
\text { rod }\end{array}$ & $\begin{array}{l}\text { The end of a tape or rod is placed at a known } \\
\text { elevation point, and the elevation of the unknown } \\
\text { point is calculated using the metered scale and, if } \\
\text { necessary, clinometers to calculate angles. }\end{array}$ & Up to $\pm 10 \%$ of elevation measurement \\
\hline $\begin{array}{l}\text { Total station or } \\
\text { Auto/hand level }\end{array}$ & $\begin{array}{l}\text { The accuracy of the elevation measurement is } \\
\text { also inversely proportional to the distance } \\
\text { between the instrument and the point being } \\
\text { measured. Furthermore, it takes over the accuracy } \\
\text { of the benchmark used when setting up the Total } \\
\text { Station or Hand levelling survey. }\end{array}$ & $\begin{array}{l} \pm 0.1 / \pm 0.2 \mathrm{~m} \text { for total station } \\
\pm 0.2 / \pm 0.4 \mathrm{~m} \text { for hand level }\end{array}$ \\
\hline $\begin{array}{l}\text { Multibeam } \\
\text { bathymetry data } \\
+ \text { core depth }\end{array}$ & $\begin{array}{l}\text { Bathymetry derived from multibeam surveys in } \\
\text { offshore areas, below which the depth along cores } \\
\text { is expressed. Errors differ with coring system } \\
\text { (gravity, vibrocoring, rotary drilling...) and should } \\
\text { be assessed case by case. }\end{array}$ & $\begin{array}{l}\text { The accuracy of modern MBES systems is } \\
\text { considered of } \mathrm{cm} \text {-scale }(<0.1 \mathrm{~m}) \text {, with main } \\
\text { errors derived from tidal correction during } \\
\text { the survey day. Core depth error sources are: } \\
\text { core shortening, non-vertical drilling, } \\
\text { compaction. }\end{array}$ \\
\hline Not reported & $\begin{array}{l}\text { The elevation measurement technique was not } \\
\text { reported, most probably hand level or metered } \\
\text { tape. }\end{array}$ & $\begin{array}{l}20 \% \text { of the original elevation reported added } \\
\text { in root mean square to the sea level datum } \\
\text { error }\end{array}$ \\
\hline
\end{tabular}

For the British Isles, local reference water levels are calculated at 44 tide gauge locations based upon multiple decades of direct measurement. This establishes the regional Chart Datums, that are used to assess the indicative range of a local modern analogues (e.g. beach crest height). Elevations reported to regional UK datums were converted to the MSL-based national OD at Newlyn (using values given by the National Oceanography Centre; ntslf.org/tides/datum). Sea level at Newlyn has risen $\sim 0.22 \mathrm{~m}$ above ODN since first established between 1915-1921. Modern MSL at Portsmouth (southern England) and Sheerness (southeastern England) is +0.14 m ODN and at Immingham (eastern England) -0.23 m ODN 
For France, all elevations are given relative to NGF-IGN69, with the 0 level mean sea level in Marseille in the Mediterranean (Table 6). MSL along the French side of the Channel (SHOM, 2020) is at $+0.5 \mathrm{~m}$ IGN69 for Brittany and approaches $+0.6 \mathrm{~m}$ in the Strait of Dover (at present, $0.10-0.15$ lower in early $20^{\text {th }}$ cy based on tide gauge data; Wöppelmann et al., 2008). The user of WALIS data may thus opt to lower French-datum related elevations by c. 0.4-0.5 m prior to entering analysis. The above geographically generalized datum-related conversions are pragmatic ones. We estimate the systematic vertical error associated to be $0.05-0.20 \mathrm{~m}$ as other sources of systematic and stochastic error in the calculation of SLIPs from the LIG are regarded greater, this approach is warranted.

Table 6: Sea level datums made use of in this study.

\section{Datum name}

Mean Sea Level / General definition

DNN

(Danish ordnance datum, prior to DVR90)

\section{NAP, NHN, NN}

(Netherlands ordnance datum, Amsterdam, also 0 level for the German ordnance datum)

TAW+2.33

(Belgian ordnance datum, Oostende, offset to get from LAT to MSL)

OD

(British Ordnance Datum Newlyn)

\section{NGF-IGN69}

(French Ordnance Datum, Marseille)

\section{Datum description}

General definition of MSL, with no indications to which datum the measurement referred to. A datum uncertainty can be established on a case-by-case basis.

DNN (Dansk Normaal Nul) is the O.D. in Denmark used during the $20^{\text {th }} \mathrm{cy}$. It is about equal to second-half $20^{\text {th }}$-cy MSL (mean half-tide) as observed in 10 tide gauges along the Danish coast. DVR90, which ties to NAP, replaced DNN in the early 2000s. $0.02 \mathrm{~m} \mathrm{DNN}$ is $0 \mathrm{~m}$ DVR90 in N Denmark; -0.14 m DNN is 0 m DVR90 in SW Denmark.

NAP (Normaal Amsterdams Peil) is the O.D. in the Netherlands, and NHN (Normalhöhennull) the German O.D. that shares the datum. The zero level is about equal to second-half 20th cy MSL (mean half-tide) as observed in tide gauges along the Dutch coast. NHN replaced precursor NN in the early 2000s, that also tied to NAP.

TAW is a datum based on Lowest Astronomical Tide (LAT) at Oostende (Belgium). $0 \mathrm{~m}$ TAW (Belgium) is $-2.33 \mathrm{~m} \mathrm{NAP/NHN}$ (Netherlands, Germany), and hence $+2.33 \mathrm{~m}$ is the datum offset. For reference: $0 \mathrm{~m}$ TAW (Belgium) is $-1.83 \mathrm{~m} \mathrm{NGF}$ (France).

In the U.K., OD is defined as the mean sea level at Newlyn (Cornwall, UK) between 1915 and 1921. For reference, modern MSL is $0.14 \mathrm{~m}$ above ODN at Portsmouth and Sheerness, and $0.23 \mathrm{~m}$ below ODN at Immingham.

NGF (Nivellement General de la France) is the ordnance datum for continental France. The zero level equates to Mediterranean mean sea level (mean half-tide) in Marseille as gauged between 1885 and 1897. For reference, 20/21 $1^{\text {th }}$-cy MSL is $0.505 \mathrm{~m}$ above NGF at Brest, 0.585 at Cherbourg, 0.491 at St Malo, 0.585 at Le Havre and 0.571 at Calais, and $0.50 \mathrm{~m} \mathrm{NGF}$ at Oostende (Belgium, see TAW). 
https://doi.org/10.5194/essd-2021-390

Preprint. Discussion started: 10 November 2021

(c) Author(s) 2021. CC BY 4.0 License.

\subsection{Compaction corrections}

Most SLIPs and limiting data points are from sites and indicator types that by their nature do not require particular compaction correction e.g., marine terraces, beach deposits, drowned valley floor and isolation basin sills (Table 3). Data points where compaction corrections have been applied are mainly to those collected from boreholes in the Netherlands, NW German and SW Danish settings that sampled basal peat, lagoonal and estuarine tidal flat type indicators. In those cases, compaction was assessed for organic and muddy beds.

665 For basal peats we assume full analogy with Holocene deposits. Where Holocene peats are overlain by 10-15 m of coastal overburden, transgressed peats are compressed to 50-33\% of their original thickness, with the greatest majority of this compression happening in the first millennia after burial (Hijma et al., 2009; Hijma and Cohen, 2011). Decompaction of decimetre-thick basal peat beds is achieved by multiplying thickness by a factor 2 to 3 (Berendsen et al., 2007; Hijma and Cohen 2019). For Eemian basal peats, the overburden is similarly thick, but in-situ for longer time and relatively sandy. We

670 hence considered a decompaction factor of 2.5 to 3.5 for dominantly organic beds, and 2 to 3 for clay-peat alternating intervals. As basal peat SLIPs and associated marine limiting indicators lie at the top of a basal peat bed (§3.2.6) this affects the elevations of data points of these types. For lagoonal and estuarine tidal flat tops, decompaction of clayey tidal deposits immediately underlying these levels is considered. It is only 'post-depositional' compaction after the tidal flat ceased to function that is to be assessed in that case; not syn-depositional 'auto-compaction' or the loading and lowering of underlying

675 basal peaty strata as that was accommodated while the tidal deposits accumulated (Brain, 2015). Subtidal clayey facies is more prone to post-depositional compaction (decompaction factor 1.5 to 2.5 ) than intertidal and supratidal facies (decompaction factor 1 to 1.5 ) because the latter had been subjected to wet-dry cycles at time of deposition (Paul et al., 2005). The amount and composition of overburden affects opting for the lower or higher side of decompaction.

680 The above types of compaction corrections are documented in the 'Notes on elevation and indicative range' field in WALIS, for each entry where it was applied. The decompaction approach was a pragmatic one. Geomechanic empirical-calibrated modelling suggests to similar decompaction factors for basal organic beds and clayey tidal lagoonal sequences (e.g. Greenfield and Tucker, 1986; Brain, 2015), as long as the post-depositional compaction component is isolated from the syndepositional one.

685

A few sites in the database are from particularly thick organo-clastic Eemian sequences, from deglaciation-inherited deep channels onshore in the German Bight (e.g. Dagebuell, Schnittlohe) and from glacial-tongue basins in the Netherlands (e.g. Amsterdam, Amersfoort; Fig. 1). We avoided defining heavily-compaction influenced sea-level markers and regression terrestrial limiting points from such localities. From the deep and thick German Bight sequences, SLIPs and limiting points 690 are only defined based upon deepest levels in the sequences, for which compaction corrections are relatively minor. The 
https://doi.org/10.5194/essd-2021-390

Preprint. Discussion started: 10 November 2021

(c) Author(s) 2021. CC BY 4.0 License.

(c) (i)

environments became subaqueous following the transgression and it is the proxy water depth inaccuracy, rather than decompaction, that affect indicator elevation position and associated uncertainty. For the Amersfoort tongue basin, the database provides additional locations close to the rims of the basins as more accurate highstand and regression indicators. For the Amsterdam tongue basin transgressive information, we define the locality as an insolation basin, as the elevation information comes from a sill in glaciogenic substrate where compaction can be ignored.

\subsection{Vertical Land Motion (VLM) correction}

VLM correction values are supplied for the North Sea Basin depocenter (Fig. 1), but not for the other regions covered in this paper. We focus on the North Sea Basin due to both its significance and precedent. Firstly, rates of VLM in the North Sea Basin are in the order of 0.1-0.2 m/kyr, meaning up to 10 meter of correction in the regions of the LIG highstand shoreline, and up to 20 meters further offshore at locations closer to depocentres. As noted in section 2.1, that spatial variation in tectonic subsidence affects how transgressive, stillstand and regressive RSLs are to be compared. Key literature compiling and using LIG sea-level datasets for Europe and globally hence have earlier applied basin-subsidence VLM values to the North Sea Basin sites (Lambeck et al., 2006; Kopp et al., 2009). Including assessed VLM values in WALIS entries allows application of such corrections to dataset to be consistent, spatially across the covered region as well as with the previous studies (for data points then included).

Areas around the margin of the North Sea Basin are thought to experience relatively minor non-GIA VLM. Very modest long-term subsidence rates may apply to NE Belgium, Denmark and N Germany during the Pleistocene, or alternatively they can be viewed as fairly stable (Kiden et al., 2002). Whether the Dover-Calais area is neotectonically active, and owing to what cause, is debated (e.g. Van Vliet-Lanöe et al., 2000; Westaway et al., 2002; Garcia-Moreno et al., 2015). The region is also known to have lost considerable volume of bedrock in Middle Pleistocene times (proglacial erosion of Dover Strait; Gibbard, 1995; Gupta et al., 2007, 2017) with some isostatic uplift in response. Regardless, the apparent uplift due to both GIA and non-GIA VLM based upon the flight of raised beaches is modest (+0.02 to $+0.04 \mathrm{~m} / \mathrm{kyr}$; Pedoja et al., 2018). Similar applies to sites along the English and French sides of the English Channel. The flight of raised beaches in West Sussex (Bates et al., 2010; Briant et al., 2019) occurs in an area where net uplift is thought to be significant, with apparent

715 rates between 0.06 and $0.12 \mathrm{~m} / \mathrm{kyr}$, explaining the mean vertical separation of highstand beaches of the last few cycles (e.g. Westaway et al., 2006). However, this rate calculation is sensitive to age-attribution (sections 2.5-2.7) and assumptions on global ice sheet history and spatio-temporal variations in the solid Earth, and again a breaking down the relative contribution of different process of uplift is complex. As a result, we do not provide a VLM value for these regions. Independent constraints on long-term VLM, separate from GIA, will be an ongoing challenge in this area.

Background VLM rates characterizing non-GIA subsidence in the southern North Sea are obtained from Kooi et al. (1998: their Figure 4, all three components totaled). They result from a tectono-sedimentary back-stripping analysis on thickness of 
https://doi.org/10.5194/essd-2021-390

Preprint. Discussion started: 10 November 2021

(c) Author(s) 2021. CC BY 4.0 License.

(c) (i)

Quaternary and Neogene sequence of the basin and presented mean rates estimated over the last 2.6 Ma. The starting point for that subsidence analysis is the mapping of Quaternary thickness in the North Sea Basin, based on offshore seismostratigraphic and onshore lithostratigraphic mappings, collated. For reanalysis and assessment of the 1998 outcomes, we generated such source materials for The Netherlands and direct vicinity with current onshore-offshore geological survey digital mapping resources, and are able to broadly reproduce the accommodation patterns and subsidence rates Kooi et al. (1998). Further offshore, mapping of the base Quaternary has been revised (e.g. Lamb et al., 2018). This shifted depocenter contours, which locally nudged VLM values with -0.03 to $+0.03 \mathrm{~m} / \mathrm{kyr}$ relative to the 1998 results. The contour lines in Fig.

7304 served as VLM-subsidence isolines where values for newer data points had to be assessed. VLM used in WALIS for this region ranges from $0.02 \mathrm{~m} / \mathrm{kyr}$ at marginal locations, to $0.24 \mathrm{~m} / \mathrm{kyr}$ at sites over Quaternary depocentres. VLM rate uncertainty is \pm 0.01 for sites along the basin margin (subsidence of -0.02 to $-0.03 \mathrm{~m} / \mathrm{kyr}$ ) and increases to \pm 0.04 in far offshore depocentres.

735 There is an indication (analysis in Barthes et al., 1999; Kuhlman et al., 2006ab and Arfai et al., 2018) that the 2.6-0 Myr averaged subsidence rate, is controlled by very strong sediment-loading subsidence induced between 2.6 and 1.8 Ma (rates higher than average), followed by much reduced subsidence after $1.8 \mathrm{Ma}$ (rates below average, estimated at $80 \%$ ). If so, the VLM value we use in WALIS should be regarded as maximum background subsidence rate. Breaks in basin subsidence trends before and after 1 Ma may be suspected for the southern North Sea, but have not been spatially quantified. Caveats of glacial-interglacial variations in the height of regional (what mean value to use, given GIA overprinting) make estimating accommodation-based long-term subsidence rates difficult for this youngest period. For this reason, the WALIS VLM-rates for the North Sea Basin relies of identification of surfaces from Early Pleistocene marine basin, below the glaciogenic 'upper regional unconformity' (cf. Ottensen et al., 2014).

745 Where we report VLM-corrected elevations for North Sea SLIPs and limiting data points in the next section, we calculated these with the midpoint numeric ages as listed in Table 4. Such projected elevations rise if points are shifted to the older side, and drop if they are shifted to younger side of the considered range. In the transect plot of Fig. 5, such will affect transgression and regression points more than highstand points (see above). For age-depth plots effects will be considerable. The uncertainties we specified for the VLM rates, propagate to vertical uncertainties when applying the VLM correction. Doing so for the Zagwijn-1983 subset, reproduces the magnitudes of uncertainty in tables and plots in Lambeck et al. (2006). The rate uncertainty specified for North Sea offshore site ' $\# 2$ ' is similar to that used in Kopp et al. (2009): -0.03 vs -0.0255 $\mathrm{m} / \mathrm{kyr}$. For the inshore sites, the rate uncertainty specified in WALIS, is roughly twice the value in Kopp et al. (2009). 


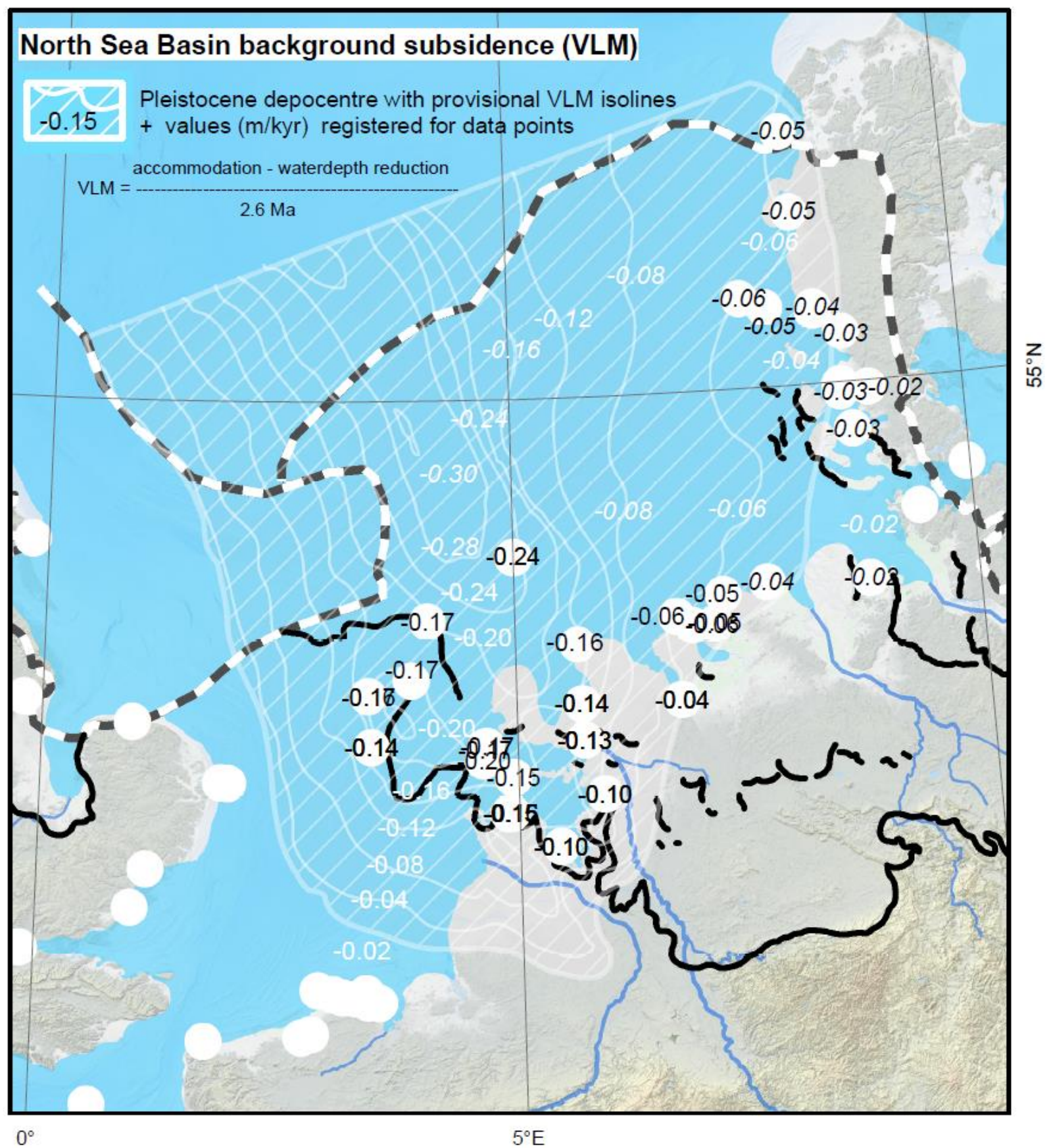

755 Figure 4: VLM values (m/kyr) for North Sea Basin LIG datapoints. Area of subsidence and VLM contours, based on depth basePleistocene in marine formations (onshore and offshore data NL, GER and DK geological surveys), negotiated for water depth reduction during the Early Pleistocene (isoline increment: $0.04 \mathrm{~m} / \mathrm{kyr}$, i.e. equivalent to $5 \mathrm{~m}$ RSL correction accumulated over 120 kyr). Values in regular font: WALIS VLM entries for LIG data points, based on Kooi et al. (1998). Values in italics: extrapolations thereof (this paper). Offshore, the subsidence patterns shown deviate subtly from those in Kooi et al. (1998), because of improved mapping of base Pleistocene. Backdrop as in Figure 1, contains land data () OpenStreetMap contributors 2020, distributed under the Open Data Commons Open Database License (ODbL) v1.0. 


\section{Overview of data points}

In this section we present an overview of data points, that for graphic representation and textual attention are grouped in:

- a main cluster coming from the 'highstand shorelines', the term used here in sequence stratigraphic rather than RSL sense, defining a general stillstand reached within the interglacial.

- a 'transgression' cluster with relatively older and relatively deeper positioned RSL data points, from the rising limb towards the highstand / stillstand;

- a 'regression' cluster, with relatively younger RSL data points, that come from positions seawards of the highstand cluster and from relatively lower elevations.

From each of these groups, SLIPs as well as marine limiting and terrestrial limiting points are present in the database, as Figures 5 and 6 show for the North Sea and Channel regions. These figures are transect plots with locations projected to a central axis. Datapoints affected by North Sea basin subsidence are plotted twice: VLM-corrected in colour, raw in gray (numeric age used to calculate correction: Table 4, middle option; subsidence rates in Fig. 4).

Lithostratigraphic (architectural, cross-sectional relationships) and biostratigraphic (regionally reproducing biogeographical successions) relative dating evidence is used to distinguish between the groups. In areas with sites where lithostratigraphic and biostratigraphic evidence is ambiguous or of coarse resolution, we place the data point in to the 'stillstand' group, to when it is not known if they are from a regressive or transgressive stage. This mainly applies to stretches of French and English coast. Sites along the Belgian, Netherlands', German and the SW Danish coast and offshore, are generally resolvable into transgression, highstand and regression phases. From Belgium to the German Bight, a stillstand is perceived during PAZ E5 ( 4000 yrs long, Table 3), and regression commences in PAZ E6. Therefore, the chronostratigraphic coding determined our grouping in this region, with points labelled as 'PAZ E5/6 break' the youngest ones in the stillstand group. In $\mathrm{N}$ Denmark and the SW Baltic the stillstand also straddles PAZ E5, but is less precisely constrained (Cyprina Clay upper saline phase; E4b-E6a) and hence may have lasted a little longer ( 4700 yrs; Table 3). Dividing the transgression and stillstand (highstand), from the perspective of continuous SLR slowing down or a difference in elevation was done in an arbitrary matter: all data points of Late Saalian to PAZ E4b chronostratigraphic age were put in the 'transgression' group (Table 1).

Figure 5 shows even numbers of 'highstand' and 'transgression' data points for the North Sea region. The English Channel coastal data in Figure 6 predominantly contains stillstand datapoints. For reference: the $\sim 4000$ years of PAZ E5-equated stillstand time (North Sea) will fall within the middle and/or the second half of MIS 5e, whereas the regression onset (equated to beginning of PAZ E6) may be toward the end of MIS 5e or into MIS 5d (options in Table 4). Across the English Channel region, the regional duration of the more broadly defined stillstand is not particularly resolved, but a stillstand in the second half of MIS 5e may be expected. The further overview is organised by region. 


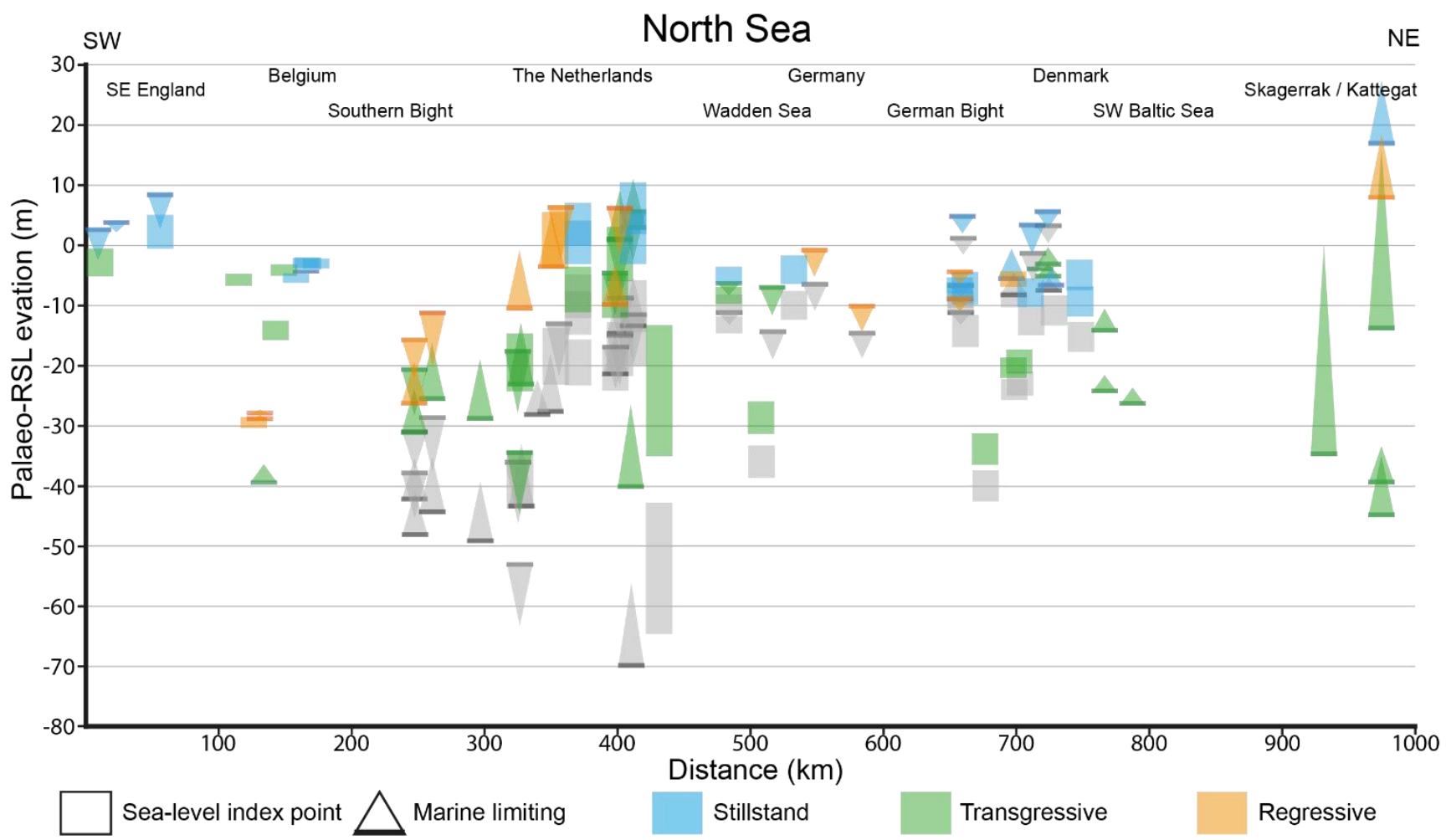

$\bigvee$ Terrestrial limiting

Without VLM correction
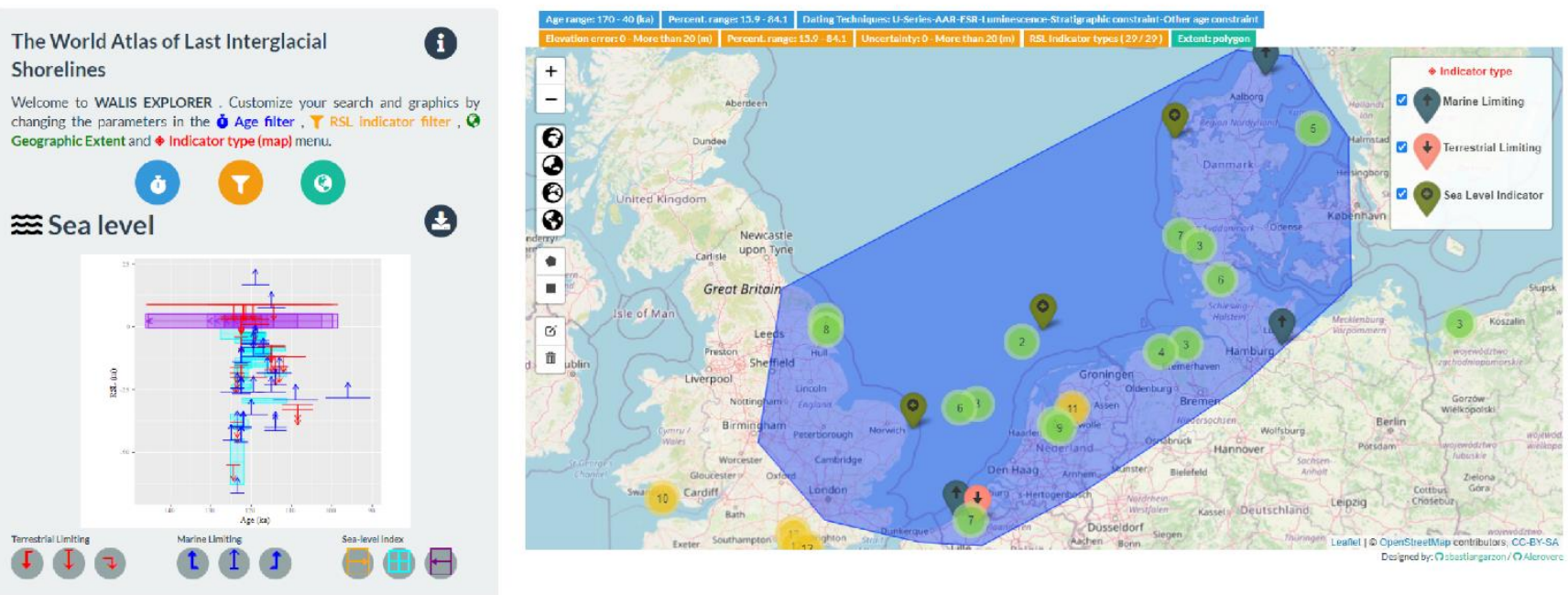

Figure 5: SW-NE organised plot of Last Interglacial WALIS data entries for the North Sea, split to type and relative position. Transect location in Fig. 1. Bottom panels shows sites and age-depth plot as a screenshot of WALIS' interactive viewer (Garzon and Rovere, 2021): https://warmcoasts.eu/world-atlas.html, which includes @) OpenStreetMap contributors 2020 data as basemap (distributed under ODbL 1.0). Only LIG data points plotted. 
https://doi.org/10.5194/essd-2021-390

Preprint. Discussion started: 10 November 2021

(c) Author(s) 2021. CC BY 4.0 License.

(c) (i)

\subsection{North Sea: Netherlands and Belgium}

For the Netherlands and Belgium, availability of national online geological datasets (e.g. Van der Meulen et al., 2013), means that all sites and boreholes in this region were looked up in web-portals to verify coordinates, surface elevations, layer depths etc. (Fig. 2b). For The Netherlands' we used www.dinoloket.nl/en/subsurface-data, for Belgium (Flanders) www.dov.vlaanderen.be. The WALIS entries include borehole IDs from these portals. Coordinates of legacy sites based on outcrops were also checked using digital topographic and aerial photography resources.

Figure 1 in the North Sea depicts the Eemian highstand coastal situation where the inner rim of the coastal plain featured deep incursions where river valleys and glaciogenic basins and outwash channels were marine inundated, dented with morainic headlands. North Sea highstand wave action during the Eemian would reshape these headlands, while long-term basin subsidence would lower their absolute elevation. Falling stage and lowstand terrestrial sedimentary process (river valley developments in the basin; Busschers et al., 2007; Peeters et al., 2016) eroded most Eemian coastal plain features (Peeters et al., 2019) . Locally terrestrial peats bearing late interglacial and early glacial palynology (PAZs E6 and EW in Table 1) formed over highstand-originating surfaces that preserved along the rims of lagoons and estuaries preserving regressive stage RSL data points. Local preservation tends to be explained by burial under periglacial colluvial-alluvial deposits from the onset of the Last Glacial (Early Weichselian, Table 1), besides the long-term subsidence.

Locally, deposits along the rim of the Eemian highstand coastal plain have preserved as lagoon- and estuary-fringe sites in the central Netherlands, most famously Amersfoort (Zagwijn, 1983; Cleveringa et al., 2000; WALIS IDs 133, 137, 138), but also at Oosterwolde (Peeters et al., 2016; IDs 134-136), Rutten (Sier et al., 2015, Peeters et al., 2016; IDs 109, 111, 114, 115), Scharnegoutum (Zagwijn, 1983; IDs 124-127) and Annen (Bosch, 1990, IDs 4260, 4261). These sites each provided multiple SLIPS and limiting points, including the final transgressive (all PAZ E4) and early regressive stages (all PAZ E6; site Oosterwolde OSL-dated). The inland-most coastal beds from the highstand ('stillstand') stage are nowadays encountered $8 \mathrm{~m}$ below MSL. With VLM-corrections, 'highstand' SLIPs (from PAZ E5) from Amersfoort plot at $+3.5 \mathrm{~m}$ MSL, and the full cloud of highstand SLIPs projects between $+1.2 \mathrm{~m}$ (Annen) and $+6.2 \mathrm{~m}$ MSL (Scharnegoutum). Four transgression phase SLIPs coming from these sites have paleoRSL depths between -21 and -13 m MSL. With VLM-correction their midpoints plot between -8.3 and -1.4 m (PAZ E4a) and between -7.1 and $+1.2 \mathrm{~m}$ (PAZ E4b). SLIP uncertainties range $\pm 0.35-1.3 \mathrm{~m}$, with decompaction uncertainties included. Propagating the VLM-correction uncertainties $( \pm 0.030 \mathrm{~m} / \mathrm{kyr})$ enlarges the error to $\pm 3.6-4.5 \mathrm{~m}$ (Figure 5).

Seaward from the Eemian coastal plain inner rim, further marine deposits are encountered but at greater depths down to -40 $\mathrm{m}$ below the coastal plain, and at -35 to $-65 \mathrm{~m}$ MSL offshore. This area provides SLIPs from during (initial) transgressive stages (coincident with PAZ E3) such as near Amsterdam (Zagwijn, 1983; Cleveringa et al., 2000; De Gans et al., 2000; Van 
https://doi.org/10.5194/essd-2021-390

Preprint. Discussion started: 10 November 2021

(c) Author(s) 2021. CC BY 4.0 License.

\section{(c) (i)}

Leeuwen et al., 2000; Beets and Beets, 2003; IDs 118-120) and offshore boreholes 'BH89/2' (Sha et al,, 1991; Beets et al.,

2005), as well as during (developed) regressive stages (coincident with PAZs E6 and EW), such as at Petten (Zagwijn, 1983:

IDs 146-148). The transgressive sites also provide critical terrestrial limiting datapoints for the transgression (PAZ E1-E2), and less critical marine limiting points from during and after transgression (PAZ E4, E5) because these covered more accurately by the inland sites described above. The transgressive SLIP from Amsterdam (ID 118) is an "isolation basin (marine connection)'. The sill-height based SLIP (PAZ E3a) occurs at -39.0 $\pm 2.0 \mathrm{~m}$ MSL (tidal amplitude and sill elevation uncertainties considered) and increases to $-19.4 \pm 4.8 \mathrm{~m}$ MSL with VLM-correction. Offshore site BH89/2 is also a glacial basin (Beets et al., 2005), and an isolation basin-type transgression-stage SLIP has been registered (ID 122; PAZ E3a) at $53.8 \pm 9.0 \mathrm{~m}$ MSL, where the large uncertainty comes from poorly defined sill location. This is the site with greatest estimated basin subsidence (Fig. 4). Applying VLM of $-0.24 \pm 0.05 \mathrm{~m}$ plots the point at $-24.1 \pm 10.9 \mathrm{~m}$ MSL (Fig. 5). The regressive SLIP for Petten (ID 148; PAZ E6b) is constructed by combining coeval terrestrial and marine limiting evidence in a transect of cores (Zagwijn, 1983), and plots at $+0.9 \pm 4.7 \mathrm{~m}$ (VLM corrected; Fig. 5). North Sea boreholes ' $\# 2$ ', ‘ \#3', ‘\#5' and '\#9' (Zagwijn, 1983) provide terrestrial and marine limiting datapoints only (IDs 309, 311, 317, 319 320, 380), as do onshore boreholes such as Noorderhoeve (ID 898; Meijer, 2002; Peeters et al., 2016).

The majority of Belgian RSL data points are estuarine tidal deposits preserved as a W-E series along the rim of the LIG Scheldt estuary (Fig. 1 and Fig 2d). They occur at relative shallow subsurface positions than in the Netherlands, with three inland SLIPs coming from pit exposures: Meetkerke (De Moor and De Breuck, 1973; Nolf, 1973; ID 3259 - see Fig 2e), Pit Dhondt and Pit Coppens (Heyse 1979; IDs 341, 345), and three more from boreholes at Waterpolder and Balgerhoeke (Heyse, 1979; IDs 338-340). The latter is the most eastward and shallowest site, preserving highstand supratidal mud (ID 339, PAZ E5) and salt-marsh peat (ID 340, PAZ E5). The other SLIPs are from intertidal levels. For PAZ E5, the NW Belgian RSL positions top between -3.1 and -2.9 m MSL (Pit Coppens, Waterpolder, Balgerhoeke). A value of -5.4 m MSL (Pit Dhondt) also associated to PAZ E5 may reflect late highstand/start of the regression. These values incorporated large modern-day outer estuary tidal amplitudes for the Scheldt, and applying no VLM. The Belgian mesotidal SLIPs have paleoRSL uncertainties ranging $\pm 0.8-1.6 \mathrm{~m}$. Reducing tidal range and considering modest subsidence (e.g. $0.02 \pm 0.02$ $\mathrm{m} / \mathrm{kyr}$ ) will raise the elevation of the Belgian points and warrants further investigation.

Westwards, the sites reveal truncated sequences lacking supratidal contacts, generating transgressive SLIPs from PAZ E4, ranging between -14.1 \pm 1.6 m MSL (Vlissegem: De Clerq et al., 2018; ID 353) and -4.1 $\pm 0.8 \mathrm{~m}$ MSL (Meetkerke), whereas terrestrial site Vossenhol (Heyse, 1979; ID 337) limits RSL to below $-4.3 \pm 0.2 \mathrm{~m}$ MSL during the same period. Offshore, borehole GR1 (De Clerq et al., 2018) reveals active tidal scour during PAZ E4, producing a marine lower limit at $-38.3 \mathrm{~m}$

865 MSL. Lastly, in southwest Belgium, boreholes at Woumen and Kellen in the IJzer palaeovalley (Bogemans et al., 2016) provide SLIPs for the LIG highstand at $-5.7 \mathrm{~m}$ MSL (ID 346; including some decompaction and assuming 2 to $3.5 \mathrm{~m}$ tidal amplitude), and at -3.1 m MSL for an older interglacial (ID 347; MIS 7). 
https://doi.org/10.5194/essd-2021-390

Preprint. Discussion started: 10 November 2021

(c) Author(s) 2021. CC BY 4.0 License.

(c) (i)

\subsection{North Sea: Germany and Denmark}

In NW Germany and SW Denmark, the LIG highstand shoreline ran roughly parallel to that of the modern Wadden Sea (Fig.

1), locally preserving tidal flat and supratidal marsh deposits below $-7.5 \mathrm{~m}$ MSL. Where the shoreline turns north in the German Bight, it shows more estuarine indentations than in present times. These inshore settings, like in The Netherlands and Belgium, produced a series of 'highstand' tidal flat surfaces topped by regressive terrestrial limiting points. These are the German sites Leybucht and Land Hadeln (Streif, 1990; 2004: ID 880-884), Danish classic site Tønder (Madsen et al., 1909; Nordmann, 1928; Friborg, 1996; IDs 865, 866) and further sites Ribe, Esbjerg, Ringkobing and Harbooere (Konradi et al., 2005; IDs 869-873). The highstand appears to span PAZ E5 fully in NW Germany. For Danish-German sites where palynological control was absent, database entries encode it as equated to 'Cyprina Clay, upper saline phase' (Table 4), which in turn correlates to PAZ E4b-E6a (following Kristensen et al., 2000; Funder et al., 2002).

PaleoRSL for these SLIPs plots at -10 m MSL in NW Germany (Leybucht, Land Hadeln) but at least -5.5 m shallower in Danish-German borderland (Tønder, Ribe; marine limiting data only). Northward into Denmark, SLIP elevations fall to between -15 to -10 m MSL (Esbjerg, Ringkobing, Harbooere). A particularity is borehole site Vovov Bakkeoer (Konradi et al., 2005; ID 874) in the West-Danish offshore area, that revealed a patch of Saalian till/outwash deposits with Eemian marine cover, bearing foraminiferal evidence for later-shallower local submergence, than that of deeper waters surrounding it (e.g Horn Reef M3; ID 864). Hence, despite being positioned offshore the location produces a highstand SLIP (E4b-E6a) at $14.3 \pm 1.3 \mathrm{~m}$ MSL. Terrestrial LIG exposures are obtained from just around modern MSL ( -4 to $+2 \mathrm{~m})$ from shallow boreholes (Esbjerg, ID 871) and a classic exposures in low cliffs along the Danish Waddensea (Emmerlev Klev; Nordmann, 1928; ID 867). They place a terrestrial limit at $-3.6 \mathrm{~m}$ MSL and at modern sea level (0 m MSL), to which inland limnic beds at Tønder add third such point at $+2 \mathrm{~m}$ (Friborg, 1996; ID 866). Deploying VLM corrections (values in Fig. 4) to the German and Danish sites, places highstand elevations between -5.2 and $+2 \mathrm{~m}$ MSL (and -7.1 $\mathrm{m}$ for Vovov Bakkeoer) and the terrestrial limit at +1.2 to $+4.4 \mathrm{~m}$ MSL. The vertical uncertainty of these SLIPs ranges between \pm 0.5 and $\pm 1.0 \mathrm{~m}$ and expands to a typical $\pm 2.5 \mathrm{~m}$ when VLM is included.

A small second set of sites are those from boreholes in the Ems estuary and West-German Wadden Isles Borkum, Norderney and Spiekeroog (Streif, 1990, 1991, 2004; IDs 885-888). These cover a transgression SLIP (Borkum; ID 886, PAZ E3b) at -

$36 \mathrm{~m}$ MSL and a coeval terrestrial limiting at -16.5 m MSL (Ems Estuary, ID 885, PAZ E3), as well as terrestrial limiting points for two stages of regression, at -8.5 m MSL (Norderney, ID 887, PAZ E6) and -16.5 m MSL (Spierkeroog, ID 888, PAZ E6b.EW-Ia), coincident with the ending of the interglacial. With differential VLM correction (values in Fig. 4), the points plot at -28.6 and -9.1 m MSL (PAZ E3 transgression), respectively -8.5 and -16.5 m MSL (PAZ E6/EW regression). Uncertainties are $\pm 0.5-1.0 \mathrm{~m}$ without and $\pm 2.5 \mathrm{~m}$ with VLM correction. 
https://doi.org/10.5194/essd-2021-390

Preprint. Discussion started: 10 November 2021

(c) Author(s) 2021. CC BY 4.0 License.

A larger third set of sites, sampling from deeper buried estuarine and marine deposits filling outwash valleys inherited from the MIS-6 deglaciation, produces transgressive SLIPs, as well as marine limiting points for the highstand, and indications regarding Late Eemian regression. The lower parts of these valley fills (below -17 m MSL typically) survived erosion by glacio-fluvial outwash systems of Last Glacial age at sites Schnittlohe (Kosack and Lange, 1985; Lambeck et al., 2006; ID 889), Dagebuell (Winn and Erlenkeuser, 1995; Winn et al., 2000; IDs 875-877), Højer (Madsen et al., 1909; Nordmann, 1925; Konradi et al., 2005; ID 868) and Horns Reef M3 (Konradi et al., 2005: ID 864) in the German Bight, and sites Krummland (Winn and Erlenkeuser, 1995; Winn et al., 2000; ID 878, 879) and Tuschenbeck (Winn and Erlenkeuser, 1998; ID 890) along the Baltic Sea German coastline (Fig. 1). Inland-most coastal and estuarine beds are encountered in these boreholes. Especially along the SW Baltic settings allowing sea-level reconstruction are otherwise quite rare, as the Last Glacial morainic limit has overrun and eroded superficial littoral LIG deposits.

Before marine inundation, most sites were limnic with imprecise water depth control, meaning that terrestrial limiting points could not be worked up. The moment of marine inundation is well established for these sites: latest at the inland position of Schnittlohe (PAZ E4), earlier in Baltic facing sites Tuschenbeck and Krummland (PAZ E3a). North Sea facing sites Horns

915 Reef M3 (basal peat), Dagebuell (beach facies at base) and Højer (shallow channel fill peat) are from valley floor rather than lake settings, which provide better opportunity to define RSLs. They register transgressive SLIPs at $-40.0 \mathrm{~m}$ MSL (ID 864, PAZ E2a), at -24 m MSL (ID 875; PAZ E3a-E4b) and at -23 m MSL(ID 868, PAZ E4) and in Figure 5 plot as $-33.8 \pm 0.6 \mathrm{~m}$, $-20.3 \pm 1.7 \mathrm{~m}$ and $-19.3 \pm 2.0 \mathrm{~m}$ MSL with differential VLM correction. From Dagebuell, Schnittlohe, Krummland and Tuschenbeck this is followed by marine limits to the highstand (PAZ 4b-E6a), the highest one at $-12.5 \mathrm{~m}$ (Krummland; ID 879), -6.8 $\mathrm{m}$ (Dagebuell, ID 876) and -4 m (Schnittlohe, ID 889), corroborating and supporting the highstand SLIPs from the first discussed set of sites (also with VLM corrections). The top of the Eemian marine sequence at Dagebuell is intertidal, and hosts a regressive SLIP at -9.7 m MSL (ID 878; PAZ E6; -3.2 $\pm 1.9 \mathrm{~m}$ MSL with VLM correction), which is rare to have from N Germany (Fig. 5). Besides abundant palynological, foraminiferal, molluscan and high-density subsurface mapping providing control on setting, paleoenvironment and relative age for the above set of sites, from the Dagebuell core U-series (base), oxygen isotopic investigations (middle), and an ESR date (top) are available, confirming MIS-5e ages (Winn et al., 2000).

Lastly, the NE of Denmark produces two deep-water marine sites, Skaerumhede I (Houmark-Nielsen, 1987; Larsen et al., 2009; ID 856) and Flakket, Anholt (Seidenkranz, 1993; IDs 857-861). The former is a deep research borehole recovering some 80 meters of deep-water facies (Lower Skaerumhede Clay Fm.) deposited in the LIG equivalent of the Skagerrak channel (Fig. 1), with developed foraminifera and mollusca biostratigraphy (Knudsen and Lykke-Andersen 1982; Knudsen et al., 2009). It allows to tie water depths of 100-200 $\mathrm{m}$ to the facies encountered at -135 m MSL and translating in a single marine limiting point (ID 856) plotting at $-17.5 \pm 17.5 \mathrm{~m}$ MSL (Fig. 5). Site Flakket is also intensively marine palynological and biostratigraphically studied (Seidenkrantz, 1993), and has a water depth history of deepening from $35 \pm 5$ to $100 \pm 10 \mathrm{~m}$ 
https://doi.org/10.5194/essd-2021-390

Preprint. Discussion started: 10 November 2021

(c) Author(s) 2021. CC BY 4.0 License.

water depth between the onset of the Eemian (ID 857; Kattegat Stadial; ID 858; PAZ E2a-E3a) and developed interglacial (ID 859; PAZ E3a-E4b; ID 860; PAZ E4b-E6a). This succession correlates with developments in the SW Baltic (Cyprina

Clay phases, Table 4) and with the zonations of boreo-lusitanian molluscan and forma invasions and deepening trends of the Skaerumhede borehole. With water depth history accounted for, the marine limiting depths rise from -40 to $-36.5 \mathrm{~m}$ MSL in the early Eemian, then accelerate to above $+1 \pm 15 \mathrm{~m}$ MSL (PAZ E3a-E3b) to stabilize above $+22 \pm 5.4 \mathrm{~m}$ MSL (highstand;

940 PAZ E4b-E6a). The top of the Flakket sequence shows a dropping water depth but the site stays marine during PAZ E6 defining a last marine limiting point (ID 861) at +13.0 $\pm 5.4 \mathrm{~m}$ MSL. The apparent superelevation of the LIG RSL data from these northwesternmost sites (Fig. 5) reflects the strong gradient in GIA fingerprint from this repeatedly ice-covered part of the study area, to the increasingly GIA-peripheral North Sea and Channel regions to the SW.

\subsection{North Sea: Thames Estuary, East Anglia, North England}

945 Sea level data points from the western North Sea coast primarily comprise of estuarine deposits from in or just above tidal frame. In the Thames, Preece (1999) describes a terrestrial limiting point (ID 3713) based upon the presence of freshwater molluscs throughout a sequence of organic silts from -2.4 to $+3 \mathrm{~m} \mathrm{OD}$, that overly a basal gravel (similar to the stratigraphy found at other locations in Trafalgar Square). The presence of the brackish water ostracod Cyprideis torosa and a few tests of the foraminifera Elphidium articulatua, which were likely carried upstream by tidal action, suggests this site was

950 deposited just beyond the limit of HAT. Similarly macro- (hippopotamus, hyaena and elephant) and micro-fossils (freshwater ostracods and molluscs) found in a channel sequence at East Mersea in Essex constrains a terrestrial limiting point (ID 3715) within the modern foreshore at $\sim 3.2 \mathrm{~m}$ OD (Bridgland et al., 1995a; Briant et al., 2012). A further terrestrial limiting point (ID 4064) is present at Bobbitshole, Suffolk, which is the type-site for the Ipswichian interglacial, with the youngest LIG freshwater deposits as indicated by pollen and molluscs at approx. +1 m OD (West and Godwin, 1957; Sparks,

955 1957). The age of each of these terrestrial-limiting sites is constrained by state-of-the-art AAR dating of Bithynia tentaculata opercula, with ascription of a MIS 5e interglacial supported by the biostratigraphy (Penkman et al., 2013).

The same AAR dating method (Penkman et al., 2013) is applied to the sequence from Tattershall Castle, Lincolnshire, where a salt marsh pollen sequence of detrital mud and organic silts contains grains of Chenopodiaceae, Plantago maritima and

960 Artemisia, alongside the brackish water ostracods and molluses Pseudamnicola confuse and Hydrobia ventrosa (Holyoak and Preece, 1985). This allows us to ascribe this site to the salt marsh indicator type and a SLIP of $-0.75 \pm 0.71 \mathrm{~m}$ OD (ID 3736). Further north, on the modern East Yorkshire coast is the only non-estuarine MIS 5e deposit from this region; a chalk boulder beach (Catt and Penny, 1966; Lamplugh, 1887), overlain by windblown sands from which OSL samples were collected and dated to $120.9 \pm 11.8 \mathrm{yr}$ (Bateman and Catt, 1996). Due to the presence of landslide material covering the LIG 965 boulder beach (visited by NLMB in 2020) there is some uncertainty as to the exact elevation of the beach (ID 1380;2.3 \pm 2.8 m OD), which had to be estimated from the field diagrams (Bateman and Catt, 1996; Catt and Penny, 1966). Offshore of Norfolk two vibrocores recorded the LIG transgression as a sedimentary succession of sands and silts sat over a unit of 
glaciofluvial gravel and gravely sand (Paddenberg et al., 2008, Russell and Tizzard, 2011). Silty deposits at ca. -29.54 m OD date to MIS 5 and display a micro-fossil assemblage dominated by the ostracod Cyprideis torosa and foraminifera Ammonia
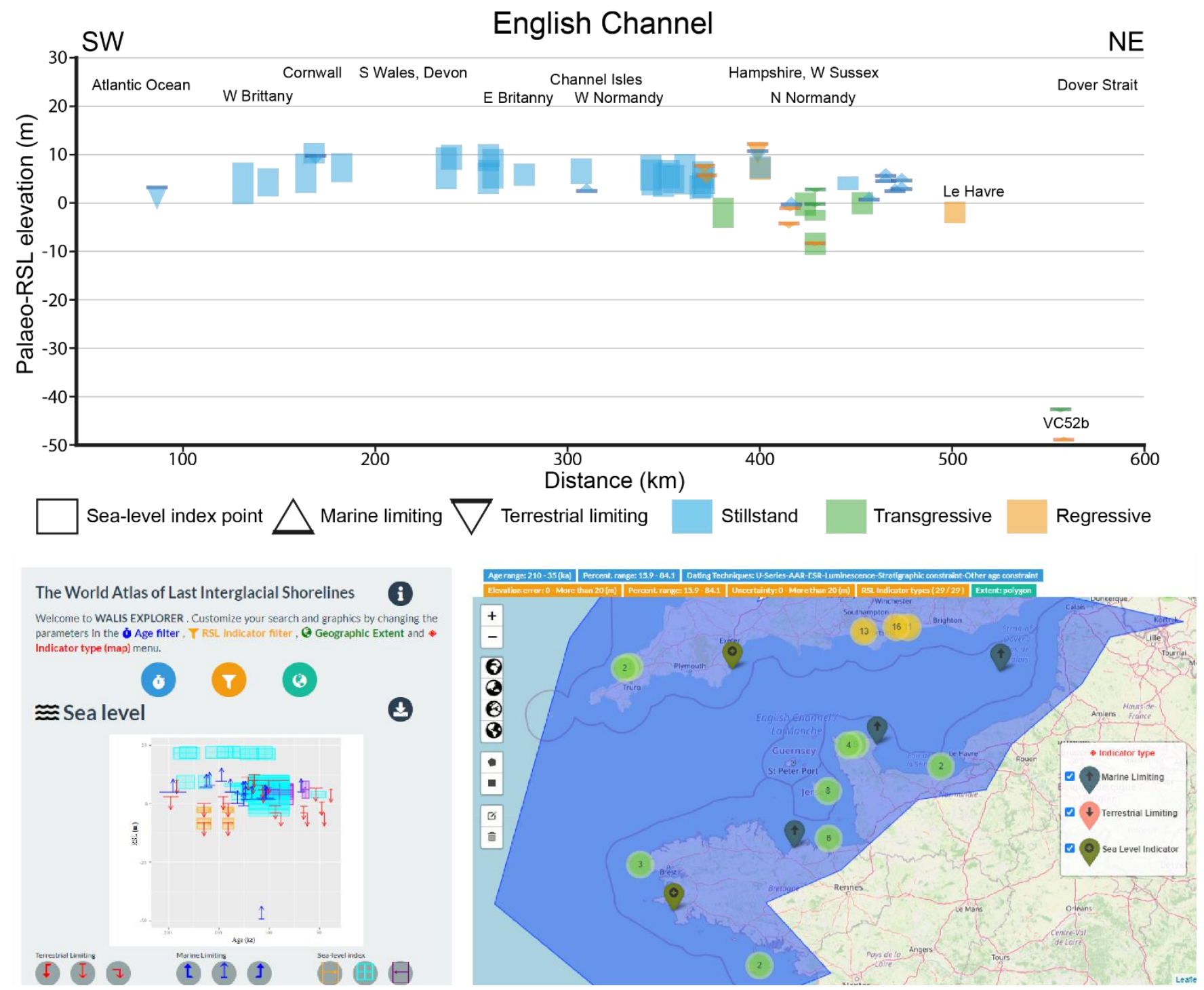

Figure 6: SW-NE organised plot of Last Interglacial WALIS data entries for the English Channel, split to type and relative position. Transect location in Fig. 1. Bottom panel shows sites and age-depth plot as a screenshot of WALIS' interactive viewer (Garzon and Rovere, 2021): https://warmcoasts.eu/world-atlas.html, which includes $\odot$ OpenStreetMap contributors 2020 data as basemap (distributed under ODbL 1.0). Only LIG data points plotted. 
https://doi.org/10.5194/essd-2021-390

Preprint. Discussion started: 10 November 2021

(c) Author(s) 2021. CC BY 4.0 License.

(c) (i)

\subsection{English Channel: Southern England}

980 Pennington Quarry (IDs 3761-3764) place buried estuarine deposits at -4.6 m OD in late MIS 5 (Allen et al., 1996; Briant et al., 2006), and provide for 'regression' stage terrestrial limits. Buried interglacial estuarine deposits associated with the Solent River estuary system are further found on the Isle of Wight in association with the Bembridge Raised Beach (ID 4004; +4 m OD), which is dated with thermoluminescence to MIS 5e (Preece et al., 1990).

Raised interglacial beaches in both Devon and Cornwall (Scourse, 1996; Campbell et al., 1998) are commonly associated 1005 within sequences of pebble conglomerate beach facies sitting on top of raised wave-cut platforms, and overlain by backshore sand facies that grade into aeolian dune sands. Four sites are included, all considered highstand/stillstand sites, of which only one (Fistral Beach, Newquay; ID 729) has a geochronology supported by thermoluminescence dating, independent from AAR (Southgate, 1985). That site dates overlying dune deposits (+9 m OD), providing a terrestrial limiting data point. The further three sites (Trebetherick, St Ives Bay, Saunton; IDs 528, 730, 735) each have AAR and stratigraphic information that 1010 indicate MIS 5 provenance (Andrews et al., 1979; Bowen et al., 1985; Davies, 1983, 1984; James, 1968, 1975, 1995, 2008; 
https://doi.org/10.5194/essd-2021-390

Preprint. Discussion started: 10 November 2021

(c) Author(s) 2021. CC BY 4.0 License.

(c) (i)

Gilbert, 1996; Scourse, 1996; Campbell et al., 1998), yet with low confidence in age quality. These plot as SLIPs at +4.2 to $+7.2 \mathrm{~m}$ OD (Fig. 6).

The remaining MIS 5-associated data points included for Southern and Southwest Britain derive from raised littoral

1015 sediments found within cave systems in South Devon (Proctor and Smart 1991; ID 4008), South Wales (Sutcliffe and Currant 1984; Stringer et al., 1986; Sutcliffe et al.1987; IDs 4005-4007), and on Jersey (Keen et al., 1981; ID 4003). Each site contains speleothem deposits in association with the raised littoral sediments providing robust chronologies based on Useries dating. The Minchin Hole Cave (IDs 4005, 4006) site in South Wales is further supported with luminescence dates (Southgate 1985). Lastly, offshore in the English Channel, vibrocores dated by luminescence record a fluvial palaeosol (ID 1020 3679) of late MIS 6 age at $-42.9 \mathrm{~m}$ OD and laminated sand (ID 3678) rich in shell fragments and shallow marine foraminifera (Elphidium sp. and Ammonia sp.) of MIS 5 age at $-48.8 \mathrm{~m}$ OD (Mellett et al., 2012; 2013).

\subsection{English Channel: Northwest France}

The most common sea level indicators in the French side of the English Channel are marine terraces and raised beaches. These features have been described from west Brittany to east Normandy as part of a staircase of coastal platforms with each step attributed to different interglacials (Coutard et al., 2006; Pedoja et al., 2011; 2014; 2018). The lower level is generally ascribed to the LIG and its age has been constrained by dating the deposits sat on top of the platforms (mainly heads, loess and beach sediments) or by the identification of Palaeolithic artefacts (Mousterian industry, Cliquet et al., 2003; 2009; 2013; Regnauld et al., 2003; Lautridou and Cliquet, 2006). Absolute ages are available at a limited number of locations and the rest of the sites are regionally correlated based on the developed stratigraphic frameworks (van Vliet-Lanoë et al., 2000; Bates et al., 2003; Regnauld et al., 2003; Monnier et al., 2011; Pedoja et al., 2018).

Marine terraces are generally found between 0 and +8 m NGF in mainland France (e.g., Trez Rouz, ID 3677; Cap La Hague, ID 3674; Asnelles, ID 3672) and in different islands distributed along Brittany's west coast (e.g., Belle Ile, ID 3667; Ouessant, ID 3658; Chausey, ID 3668). In Brittany, dune sands from deposits overlying an abrasion platform at Du Guesclin 1035 (ID 3659) were dated by Regnauld et al. (2003) providing a minimum age of $90 \mathrm{ka}$, and artefacts attributed to early Palaeolithic age were found overlying an equivalent platform at Le Verger (Regnauld et al., 2003; ID 3660). Absolute ages pointing to MIS 5 were also obtained from raised beach deposits at $+8 \mathrm{~m}$ NGF at Piégu (ID 3657) by ESR on quartz grains (Bahain et al., 2012). Normandy shows the highest density of LIG sites, particularly around the Cotentin peninsula, including a suite of sea level index points, and marine and terrestrial limiting data. Sandy beach deposits that are found between 4 and $10407.9 \mathrm{~m}$ NGF (IDs 3550, 3551, 3646, 3651, 3671) have been dated by OSL and TL to MIS 5, probably MIS 5e (Folz, 2000; van Vliet-Lanoë et al., 2006; Coutard et al., 2006; Cliquet et al., 2009), while aeolian sands (mainly dunes, IDs 3536, 3549, 3648) and marine deposits (ID 3552) provide ages for marine and terrestrial limiting points. Further east, in Le Havre, beach 
https://doi.org/10.5194/essd-2021-390

Preprint. Discussion started: 10 November 2021

(c) Author(s) 2021. CC BY 4.0 License.

(c) (i)

sediments found at -1 m NGF (ID 3676) has been interpreted as MIS 5e regressive deposits based on its stratigraphic position (Breton et al., 1991; Lautridou et al., 2003), but absolute ages are not available.

\section{Chronological challenges}

One of the challenges of any LIG sea-level database is the chronostratigraphic constraints, as developing chronologies for Pleistocene timeframes is outside the reach of radiocarbon dating. Even in low-latitude regions where absolute U-series dating can be applied to palaeo-corals, debate on the age constrains remains (e.g., Chutcharavan and Dutton, 2021). In our study area, the MIS-6 glaciation limit divides the study area and the dataset quite evenly ( $\mathrm{N}=68$ within the glaciation limit, $\mathrm{N}=73$ outside). For locations within the ice limit, the lower stratigraphic boundary left by the ice provides a strong maximum chronological constraint. In this area, the primary chronological challenge (section 6.1) is determining the absolute ages for the Eemian pollen biozones, as outlined in section 3.3 (Table 4). Outside of the ice margin, the limited lithostratigraphic controls means that assigning a pollen biozone to a specific one interglacial is a challenge, though recent advances in AAR dating has led to some progress to resolve this problem (section 6.2). The chronological particularities and uncertainties of the North Sea region affect the basin subsidence corrections and graphic comparison of WALIS-visualised data against earlier work and syntheses (section 6.3).

\subsection{The floating Eemian PAZs and their absolute chronology controversies}

The North Sea PAZ entries in WALIS' chronostratigraphy relational tables (section 3.3, Table 4), bracket the floating E1-E6 scheme between two absolute numeric ages: $127 \mathrm{ka} \mathrm{(acclaimed} \mathrm{earliest} \mathrm{possible} \mathrm{start} \mathrm{of} \mathrm{PAZ} \mathrm{E1)} \mathrm{and} 110 \mathrm{ka}$ (latest possible ending of PAZ E6). This totals 17,000 years, which broadly equals estimates of the length of the LIG globally (Lisiecki and Raymo, 2005: 130-115 ka for MIS 5e), but is longer than the varve-counted 11,000 years of the scheme itself. Hence a user requiring absolute time control must decide where on the absolute time scale the Eemian starts, for which with current dating and correlation uncertainties, multiple scenarios exist (refs in section 3.3). The literature thus associates different numeric ages to PAZ E1-E6. This spread in ages was taken over in WALIS, but with some filtering. The resulting suggested 'youngest' options may be more controversial than the 'oldest' options, and where the oldest option is put, may be debated on itself.

The youngest time option to consider is to have E1-E6 span 121 to $110 \mathrm{ka}$. In this option, the E5/E6 boundary is put at 115

$1070 \mathrm{ka}$ (Table 1), which would mean that climatic cooling and the start of the regression in the region correlate with global signals seen in Greenland ice-cores, deep-sea oxygen isotopes and coral-data dominated LIG sea-level history compilations (e.g. NEEM community members, 2013). The reason that the onset is as late as $121 \mathrm{ka}$, is that it would include the Blake palaeomagnetic event early on (Sier et al., 2015). Opting for this is controversial, as it implies that North Sea temperate 
https://doi.org/10.5194/essd-2021-390

Preprint. Discussion started: 10 November 2021

(c) Author(s) 2021. CC BY 4.0 License.

(c) (i)

conditions started $>5,000$ years later than the onset of the interglacial conditions as considered in Southwestern Europe

(Portuguese shelf: Sanchez-Goñi et al., 1999; Shackleton, 2002; 2003: 126 ka; Italian speleothems and Portuguese shelf: Tzedakis et al., 2018: 129 ka). It would imply that greater temperature gradients existed N-S across Europe than in the Holocene. Explanations are sought in Scandinavia taking relatively longer to lose remaining ice mass (Kukla et al., 2002), with repercussions for GIA and RSL (Long et al., 2015), both regionally and globally. One should only adopt the youngest option, if one assesses scenarios where the Eemian course of events differed greatly from the Holocene.

Placing the start of the NW European Eemian at $124 \mathrm{ka}$ is less controversial (this was the choice for Fig. 5 and 6). Placing the onset at $127 \mathrm{ka}$, the oldest option, is not controversial. The time differences with the onset in Southwestern Europe then are $\sim 5 \mathrm{kyr}$ (still some millennia a strong temperature gradient) and $\sim 2 \mathrm{kyr}$ (a 'near-simultaneous' onset) respectively. Such is more in line with Holocene analogies, both in terms of the duration of the Scandinavian deglaciation and the timing of regional GIA response to unloading. Investigating this further is an important foreseen application of the WALIS data, in terms of the sea-levels signals (see section 7.1), and may also contribute to resolve the course of events of LIG regional environmental and climatic change from South to Northern Europe.

An even older onset of the Eemian and hence the onset of sea-level rise in the North Sea, has been proposed by some authors, notably: Funder et al. (2002): $132.5 \mathrm{ka}$ and Beets et al. (2006): $131 \mathrm{ka}$. We filtered them (i.e. rejected them as oldest possible ages), because these ages onsets so early appear now falsified by the Portuguese shelf studies that put the onset at $\sim 126 \mathrm{ka}$, then pushed back to $\sim 129 \mathrm{ka}$ (Tzedakis et al., 2018), but not back to 131 or $132.5 \mathrm{ka}$. In the case of Funder et al. (2002), the $132.5 \mathrm{ka}$ age was based on a preliminary U-series chronology for midpoint Termination II that had $\sim 135 \mathrm{ka}$ as age, to which their interglacial onset lags $2.5 \mathrm{kyr}$. Starting from the presently considered midpoint of Termination II, the onset would be at $127.5 \mathrm{ka}$, coinciding with the 'suggested oldest option' (i.e. not controversial).

Lambeck et al. (2006) provides a GIA modeling study for Europe with focus on the MIS 6 to MIS 4 time period. It uses an ice history with the Warthe substage maximum set at 143-140 ka and midpoint Termination II and onset Eemian as in Funder et al. (2002). It reproduces the RSL curve of the Zagwijn (1983) data (Fig. 2a, Fig. 7) and from the cessecation of rise 1100 (transgression) in the curve, deduces that 1.5-2.0 kyr further shifting is appropriate. Their 4.0-4.5 kyr after the midpoint termination is 126-125.5 kyr on the current time scale. In this sense, the Lambeck et al. (2006) arrive results are in line with the 127 kyr adviced 'oldest to consider' age.

What surfaces from the above summary of the age options and reasoning behind it, is that the different advocated ages for 1105 onset of the Eemian (E1-E2), end of transgression / begin stillstand (E4b/E5), begin of regression and/or cooling (E5/6) and onset of the Weichselian (E6/EW), all include dependencies to one or more ages from isotopic records, which in turn have been subject to revision and choice. This is the nature of correlative means of establishing numeric ages, and the effect of 
https://doi.org/10.5194/essd-2021-390

Preprint. Discussion started: 10 November 2021

(c) Author(s) 2021. CC BY 4.0 License.

\section{(c) (1)}

slowly increasing overall resolution and discovery of new records and techniques (U-series dating improvements). The sources from which tie-point ages were taken are (i) marine stacked records (e.g. the Termination II midpoint of Table 1; cf. Lisiecki and Raymo, 2005 who derived it from Shackleton 2002, 2003), (ii) events in the Greenland ice-cores (e.g. Sirocko et al., 2005, for the ending of the interglacial), and (iii) ages established with U-series dating from higher resolution speleothems and transferred to single marine isotopic records (most recently: Tzedakis et al. 2018).

The revision of the interglacial onset age for Southern Europe to $~ 129$ ka by Tzedakis et al. (2018) coincides with revision of

1115 the midpoint Termination II in the same record to $\sim 132 \mathrm{ka}$. The age should thus be seen as 3 kyr into the interglacial as recorded in main marine isotope signals, which was also the idea of putting $\sim 127 \mathrm{ka}$ as oldest onset, relative to the midpoint Termination II at $\sim 130 \mathrm{ka}$, that is also the start age considered for MIS 5e used in WALIS during preparation of the dataset. This oldest' option has $\sim 2$ kyr lag time between onset interglacial in SW Europe at $\sim 129$ ka and the onset interglacial in In the North Sea part of our study area. The findings in Tzedakis et al. (2018) in Southern Europe may be reason to also push

1120 Table 4's oldest ages back to $\sim 129 \mathrm{kyr}$, as that would offer the the zero-lag time option to WALIS users too. Similarly, we should then also consider to update other elements in WALIS, i.e. the table storing peak, start and end age of the MISs ('form_MIS_ages'; Rovere et al., 2020), but the entry for MIS 5e is very widely used across the database and such changes could propagate.

\subsection{Time control and data filtering in England and France}

1125 In the British Isles, biostratigraphy has also been typically used to characterise the sites into the pollen sub-stages of the 'Ipswichian' and the preceding 'Hoxnian' interglacials (West, 1977), but without the same lithostratigraphic constraints as in continental Europe, or the presence of a full Ipswichian pollen profile at a single site. It has since been shown that these 'pollen interglacials' have very similar vegetation profiles and in fact represent more than one interglacial (Thomas, 2001; Turner and West, 1968), with many early 'Ipswichian' sites conflated with those from MIS 7 (Lewis et al., 2011; Bridgland, 1994), and the 'Hoxnian' pollen spectra shown to be very similar in both MIS 9 and 11 (Roe et al., 2009; Thomas, 2001). Due to the limited litho-stratigraphic controls of UK Ipswichian sites, the lack of continuous a pollen profile (Lewis et al., 2011; Thomas, 2001), and the difference in the marine climate of the UK versus the relatively continental northwest European plain, it is not possible to simply correlate the 'Ipswichian' pollen zones with the Eemian zones from NW Europe (Turner, 2000). Though dating approaches have significantly improved since many of UK 'Ipswichian' sites were first studied, not all sites are available to be revisited with modern methods; and therefore, several sites which some may consider to be evidence for LIG sea level have been discounted from our database e.g Somersham, Cambridgeshire (West et al., 1999), Kirmington, Lincolnshire (Straw, 2018), Burtle Beds, Somerset (Kidson and Heyworth, 1976), plus 6 of the 7 Thames sites in Hollin's (1977) analysis (section 2.5). Furthermore, questions around microfossil and sediment reworking/preservation e.g. Tattershall Thorp, Lincolnshire (Holyoak and Preece, 1985) and Somersham (West et al., 1999),

1140 and debate around the presence/absence of fauna and flora during specific interglacials (e.g., Meijer and Preece, 2000) means 
https://doi.org/10.5194/essd-2021-390

Preprint. Discussion started: 10 November 2021

(c) Author(s) 2021. CC BY 4.0 License.

(c) (i)

sites that cannot conclusively be ascribed to a single interglacial period, or indicative meaning, are excluded from the database.

To address some of the issues in biostratigraphic chronology across Britain, relative dating of interglacial coastal sites using

1145 amino-acid racemisation (AAR) began in 1979 (Andrews et al., 1979; Miller et al., 1979) and continued apace throughout the 1980s (Keen et al., 1981; Campbell et al., 1982; Davies 1983; Andrews et al., 1984; Bowen et al., 1985; Davies and Keen 1985). Such investigation was also performed on material from multiple marine interglacial sites collected from across Europe (Miller and Mangerud, 1986). A landmark review of these early works is given in Penkman et al. (2010). Early AAR results often indicated potential associations with two or more interglacial periods within individual sites, or even multiple

1150 ages within single interglacials. Major challenges were the evolving preparation procedures and inconsistent choices of species for sampling, which both hindered comparability of AAR values across different studies. Around the same time, results from the application of novel dating techniques to raised interglacial deposits in the region were being used to inform the AAR debate. U-series dates from the raised beaches at Belle Hogue Cave on Jersey (Keen et al., 1981) and at Minchin Hole (Sutcliffe and Currant 1984) and Bacon Hole (Stringer et al., 1986) in South Wales were often cited to correlate AAR-

1155 dated deposits to MIS 5e (Davies 1983; Bowen et al., 1985; Davies and Keen 1985; Bridgland et al., 1995b), although single U-series dates were insufficient for describing the full complexity of single sites given the multiple (age) groupings that were often present within AAR analyses. Early thermoluminescence techniques were also being used at this time (Southgate 1985) but were still unable to distinguish interglacial associations as results from fine grained and large grained sand fractions provided dates of MIS 5e or MIS 7, respectively.

1160

Improved certainty in the AAR debate was only reached in 2013 when an aminostratigraphy for the British Quaternary was developed using the opercula or the gastropod species Bithynia tentaculata (Penkman et al., 2013). Unfortunately, none of the existing AAR results from interglacial coastal sites in southern and southwest Britain were based on this species, and material from only limited sites in eastern England is available, and therefore definitive age determinations for many of these 1165 sites remain elusive, resulting in some sites being excluded from the database. Subsequent development and application of luminescence and U-series dating techniques has gone some way to confirming interglacial associations at several sites (Preece et al., 1990; Proctor and Smart, 1991; Bates et al 2010; Briant et al., 2019), though there are numerous sites in both the UK and France that lack independent dating control (e.g., Tastet, 1999, Haslett and Curr, 2001). With a few exceptions, most of the sites in northern France have been attributed to the MIS 5 based on absolute ages that were obtained from 1170 deposits overlying or underlaying the LIG features, and in most cases these results are not enough to discard older or younger stages as the origin, There remains considerable opportunities to revisit many (known and as yet undescribed) interglacial raised beach sites across southern and southwest Britain and France and to apply now established sea-level research protocols (Shennan et al., 2015) and spatially intensive geochronology sampling strategies that could combine with statistical (e.g. Bayesian) frameworks to greatly advance knowledge and data precision across this region. 
https://doi.org/10.5194/essd-2021-390

Preprint. Discussion started: 10 November 2021

(c) Author(s) 2021. CC BY 4.0 License.

(c) (i)

\section{Closing Remarks}

\subsection{Near Field importance in resolving global Last Interglacial sea levels}

The main foreseen usage of this database for the North Sea and Channel as Near Field region of the European ice sheets, is in GIA modelling and analysis of RSL fingerprints to appropriately attribute these to southern and northern hemisphere respective sources. The pattern and magnitude of RSL change at near field sites, proximal to existing or former ice sheets,

1180 are strongly dependent on the magnitude and timing of the change in ice load and the relaxation characteristics of the underlying mantle (Farrell and Clark, 1976; Yokoyama and Purcell, 2021). Therefore, near field sea level observations have the power resolve ice sheet histories and changes in the solid Earth that far-field data do not; as has been extensively demonstrated with near and intermediate field Holocene RSL data (e.g., Lambeck, 1995; Peltier, 2002; Lambeck et al., 2006; Bradley et al., 2011; Engelhart et al., 2011; Long et al., 2011). The relative density of data in NW Europe, over a transect

1185 away from the Saalian ice sheet margin (Figs 5 and 6), means RSL data from this region has the potential to reconstruct the magnitude and deglaciation of the MIS 6 Eurasian ice sheet, which is currently poorly constrained and important for both near and far-field LIG sea level (Rohling et al., 2017; Dendy et al., 2017). Near-field sites can also take advantage of the sea-level fingerprint of ice sheet mass balance changes to constrain the source of ice sheet melt (Tamisiea et al., 2001; Mitrovica et al., 2009). Ongoing debate suggests asynchronicity between the timing of the contribution of the Greenland and

1190 Antarctic ice mass loss to LIG barystatic sea level (Rohling et al., 2019; Turney et al., 2020); a hypothesis which near-field RSL data can test (Kopp et al., 2009; Hay et al., 2014; Long et al., 2015).

One of the challenges of near field RSL data is that regional GIA is a dominant component of the overall sea-level signal. This does in turn present advantages, as alongside long term VLM, GIA can provide the accommodation space for the 1195 accumulation and preservation of (near-)continuous late Quaternary sedimentary packages (e.g. Eaton et al., 2020). Interglacial RSL highstands will occur earlier in the far field than the near field due to solid Earth processes, with the initial transgressive phase being relatively slow and therefore having the potential to capture fluctuations in RSL (Cohen et al., 2012; Long et al., 2015). Then at the end of the interglacial, RSL fall in the near-field is relatively rapid, as changes in ocean volume due to growth of ice sheets of the commencing glacial phase, outpace regional GIA. Near-field sites often include 1200 temperature and high-latitude estuarine sequences (e.g. salt marsh) which due to their close relationship with tidal levels has the potential to provide accurate and precise vertical constraints on RSL (Shennan et al., 2015); with developments in chronological techniques only enhancing their potential to deliver $5^{*}$ LIG SLIPs. This needs to be an area of intensive research focus, as near-field RSL constraints from pervious warm periods are essential to identify the sources and forcing mechanisms responsible for sea-level change (Dutton et al., 2015). 
https://doi.org/10.5194/essd-2021-390

Preprint. Discussion started: 10 November 2021

(c) Author(s) 2021. CC BY 4.0 License.

(c) (i)

\section{$1205 \quad 7.2 \quad$ Comparison to older interglacials}

For older interglacials, the current version of the NW Europe database contains a modest subset (Fig. 1): 5 SLIP sites along the North Sea (Morton, Norfolk UK; Sangatte; NW France, Kellen, Belgium; Noorderhoeve and Ameland in The Netherlands; IDs 4063, 3665, 347, 895, 429), and along the Channel the OSL-dated Aldingbourne raised beach (West Sussex, UK - see 5.4). All of these are attributed to MIS 7 (Gale et al., 1988; Hoare, 2009; Balescu et al., 1997; Bogemans et

1210 al., 2016; Meijer et al., 2021) and all of them are from highstand positions. As for the LIG highstand, the indicators occur in raised position along English Channel, East Anglia and also in the Dover Strait (Sangatte). They occur in subsided position in The Netherlands (VLM rates included in database and Fig. 4). The series of MIS-7 attributed sites along the Thames Estuary (section 6.1) has not been entered. Our compilation efforts focused on the LIG. We do recommend to expand WALIS' contents also with such entries for older interglacials.

The Belgian site is from the IJzer-valley and in facies and setting similar to the LIG counterpart Woumen (Bogemans et al., 2016; ID 346). The Morton site is a beach deposit with no clear nearby counterpart in East Anglia. Sangatte is also without preserved LIG counterpart, attributed to Holocene highstand erosion (section 5.5). The Dutch sites (Meijer, 2002; Meijer et al. 2021; IDs 429, 895), are from estuaries overridden by the MIS-6 glaciation. In terms of depositional environments, they

1220 are similar to LIG and Holocene settings, but in terms of geographic position and orientation they are dissimilar. Geological Survey investigations in the Northern Netherlands (Bosch, 1990; and later and ongoing work) reveals a complex of glaciogenic (older than MIS 6), estuarine and fluvial deposits, including regionally traceable peat and shallow intertidal levels, similar in degree of preservation as such from the LIG. This will certainly provide opportunity to add olderinterglacial RSL data points from this region in the near future contributing to insights in sea-level position during the 1225 Middle Pleistocene, potentially not solely ‘highstand' but also ‘transgression’ data points.

\subsection{Comparison to Holocene sea level indicators}

For reasons of brevity and focus, we only loosely referred to Holocene record and do not attempt to provide an overview. There is a long history of research into Holocene RSL sea-level indicators from this region, in particular in the UK and Netherlands (Shennan, 1989; Flemming, 1982; van de Plassche, 1982), the databases of which provide the foundation for the 1230 design of modern RSL databases (Hijma et al., 2015). For recent datasets, we refer to Vink et al., (2007) and to HOLSEA regional publications (Shennan et al., 2018; Hijma and Cohen, 2019; Bungenstock et al., 2018). It should be realised, however, that analogies drawn between Holocene and the LIG are implicit part of the data review and reformatting exercise for this paper and the WALIS database, in particular the indicative meaning (Shennan, 1986; van de Plassche, 1986). 
https://doi.org/10.5194/essd-2021-390

Preprint. Discussion started: 10 November 2021

(c) Author(s) 2021. CC BY 4.0 License.

(c) (i)

\subsection{Future data collection directions}

1235 In this data paper, we separated transgression, highstand/stillstand and regressive groups for graphic presentation and to guide the provided overview. The last part of the transgression, the highstand, and the very beginning of regression is fairly covered and internally replicated, by over 50 datapoints from the area, with some sites even providing 2-3 successive SLIPs. In comparison, the earlier rising limb (first half MIS 5e) is not yet well covered, and neither is the falling stage (MIS 5 as a whole, and continuing in MIS 4 and 3).

The transgressive part of the data set (Table 1), potentially includes record of acceleration and deceleration phases in nearfield regional RSL, that in far-field RSL records are more cryptically or not recorded. Even with VLM corrections deployed, the mean uncertainty of individual transgressive SLIPS $(\mathrm{N}=19)$ is $\pm 2.5 \mathrm{~m}$ in the NW-European database and is $\pm 1 \mathrm{~m}$ for the best sites. At present, the set of transgressive slips, especially those from the earlier part of the transgression, suffers from being spatially distributed and each site needing its own VLM corrections (that are uncertain, section 4.3) to resolve the transgression signal and quantify contemporary rates of RSL. In this light, targeted collection of a series of transgressive SLIPS from along submerged Saalian palaeorelief off the Dutch coast (setting in Cartelle et al., 2021) has been caried out (ERC RISeR project; Barlow cs.), and are anticipated to append the current dataset.

1250 The offshore 'regression' data points in the data set (Fig. 1), likely include signal from RSL oscillations and (sub)highstands of MIS5c and MIS 5a (Table 1: Falling stage), and potentially even from within MIS-3. The number of datapoints is sparse for this timeframe, however, and a data collection effort with different strategy than for the LIG highstand is required to resolve the signal. The offshore record potential for the Late Pleistocene is not restricted to terrestrial limiting data from fluvial settings alone, but also includes marshy deltaic and shallow marine strata. Potential appears particularly large in the

1255 Southern Bight, where new generations of seismic surveying instruments and analysis capacity are used for targeted vibrocoring of submerged landscape features (e.g. Missiaen et al., 2020), including at places with sea-level indicative potential. In this area and region, falling stage sea-level research interest links up with that for Neanderthal and Mesolithic archaeology (e.g. Hijma et al., 2012), and with intensifying human activity in the near shore for windfarm construction and dredging for coastal nourishment and seaward harbour extensions (e.g. Cartelle et al., 2021). Such adds to demand for insight into

1260 regional RSL history of MIS 5 (that the WALIS database may cater), and to data collection potential from which research may profit. Lastly, the potential for MIS 5c-a RSL datapoints is not restricted to just offshore, but extends to the North Sea coastal zone and the western rim of Holland, where basal parts of younger than LIG estuarine and fluvial-tidal channels appear preserved below younger Rhine and Rhine-Meuse deposits (Törnqvist et al., 2000; Wallinga et al., 2004; Busschers et al., 2005; 2007; Hijma et al., 2012; Peeters et al., 2016), with OSL-dating the most readily deployable dating technique in that setting, as also offshore (e.g. Mellett et al., 2012; 2013; De Clercq et al., 2019). 
On land, new data collection in general need not be constrained to finding new sites. Many sites from older literature with some effort are still possible to revisit, collect new data from and upgrade the quality of the chronologies. This has been carried out with focus on older interglacials in southern and eastern England (iGlass project NE/I008675/1; Long et al., 2015; Barlow et al., 2017) and the three (!) rounds of re-coring and resampling for Dutch site Amersfoort (section 2.1) and 1990ies work at Tønder (Friborg, 1996) and Dagebuell (Winn et al., 2000) can also be classified as scientifically successful revisits. Importantly, choices of what legacy site to visit could be more geographically inspired (filling gaps), instead of returning once again to classic sites that are known to be quite good already.

\section{Data availability}

1275 The NW Europe database (Cohen et al., 2021; https://doi.org/10.5281/zenodo.5608459), as a scientific product, is open access. The data points used in this study were compiled and contributed to WALIS by the authors (see section 2) and in various ways the entries cross-refer to (i) governmental databases (with public portals, but their contents not open data / open access in the academic output sense) and (ii) to tabulated and graphed data contained in recent and legacy literature (in great majority web disclosed, not in all cases open access, DOI referenced where appropriate). The files at this link were exported from the WALIS database interface on 27 October 2021. A description of each field in the database is contained at https://doi.org/10.5281/zenodo.4459297 (Rovere et al., 2020), readily accessible and searchable at https://walishelp.readthedocs.io/en/latest/ More information on the World Atlas of Last Interglacial Shorelines can be found at https://warmcoasts.eu/world-atlas.html. Users of our database are encouraged to cite the original sources alongside with our database and this article.

\section{Author contributions}

$\mathrm{KMC}, \mathrm{RB}, \mathrm{VC}$ and NLMB each reviewed regional bodies of literature (see section 2), compiled the data, assigned indicative meanings, and documented WALIS database entries that underpin this paper. KMC and VC prepared figures and tables. FSB and KMC assessed North Sea basin subsidence VLM. All authors edited the manuscript (in the template of the WALIS database special issue), designed figure and table legends, and addressed referee comments.

\section{Competing interests}

The authors declare that they have no conflict of interest.

\section{Special issue statement}

This article is part of the special issue "WALIS - the World Atlas of Last Interglacial Shorelines". It is not associated with a conference. 


\section{Acknowledgements}

This paper forms a contribution the RISeR project, which has received funding from the European Research Council (ERC) under the European Union's Horizon 2020 research and innovation programme (grant agreement no. 802281; PI Barlow). The authors acknowledge PALSEA, a working group of the International Union for Quaternary Sciences (INQUA) and Past

1300 Global Changes (PAGES), which in turn received support from the Swiss Academy of Sciences and the Chinese Academy of Sciences. We are grateful to Alessio Rovere (WALIS lead and special issue editor) for guidance and assistance in the preparation of this paper, Kirsty Penkman (University of York) for discussion of the AAR data compilation, Sebastian Garzon (internship student from University of Münster) for developing the WALIS visualization interface and Amy McGuire (University of Leeds) and Chronis Tzedakis (University College London) for discussion around UK interglacial pollen. The data used in this study were compiled in WALIS, a sea-level database interface developed by the ERC Starting Grant WARMCOASTS (ERC-StG-802414), in collaboration with the PALSEA (PAGES-INQUA) working group. The database structure was designed by Alessio Rovere, Deirdre Ryan, Thomas Lorscheid, Andrea Dutton, Peter Chutcharavan, Dominik Brill, Nathan Jankowski, Daniela Mueller, Melanie Bartz, Evan Gowan and Kim Cohen. Reviews and comments by (TO FOLLOW) greatly helped in preparation of the final paper.

\section{References}

Abbott, L.: The section exposed in the foundations of the new Admiralty Offices, Proceedings of the Geologists' Association, 12, 346-356, 1892.

Allen, L.G., Gibbard, P.L., Pettit, M.E., Preece, R.C., and Robinson, J.E.: Late Pleistocene interglacial deposits at 1315 Pennington Marshes, Lymington, Hampshire, southern England. Proceedings of the Geologists' Association, 107(1), 3950, 1996.

Amkreutz, L., Cohen, K, Hijma, M., and Odé, O.: Verdrinkend land in Kaart, in: Doggerland, verdwenen wereld in de Noordzee, edited by: Amkreutz, L. and van der Vaart-Verschoof, S., Rijksmuseum van Oudheden / Sidestone press, 3337, 2021.

1320 Andrews, J.T., Bowen, D.Q., and Kidson, C.: Amino acid ratios and the correlation of raised beach deposits in south-west England and Wales. Nature, 281, 256-258, 1979.

Andrews, J.T., Gilberston, D.D., and Hawkins, A.B.: The Pleistocene succession of the Severn Estuary: a revised model based upon amino acid racemisation studies. Journal of the Geological Society of London, 141, 967-974, 1984.

Antoine, P., Lozouet, N. L., Chaussé, C., Lautridou, J. P., Pastre, J. F., Auguste, P., Bahain, J.-J., Falguères, C. and Galehb,

B.: Pleistocene fluvial terraces from northern France (Seine, Yonne, Somme): synthesis, and new results from interglacial deposits, Quaternary Science Reviews, 26(22-24), 2701-2723. https://doi.org/10.1016/j.quascirev.2006.01.036, 2007.

Arfai, J., Franke, D., Lutz, R., Reinhardt, L., Kley, J., and Gaedicke, C.: Rapid quaternary subsidence in the northwestern German North Sea. Scientific reports, 8(1), 1-12, https://doi.org/10.1038/s41598-018-29638-6, 2018.

Arkell, W.J.: The Pleistocene Rocks at Trebetherick Point, North Cornwall: Their interpretation and correlation. Proceedings of the Geologists’ Association, 54(4), 141-170, https://doi.org/10.1016/S0016-7878(43)80001-8, 1943. 
Bahain, J.J., Falguères, C., Laurent, M., Shao, Q., Dolo, J.M., Garcia, T., Douville, E., Frank, N., Monnier, J.L., Hallégouët, B., Laforge, M., Huet, B., Auguste, P., Liouville, M., Serre, F., and Gagnepain, J.: ESR and ESR/U-series dating study of several middle Palaeolithic sites of Pléneuf-Val-André (Brittany, France): Piégu, Les Vallées and Nantois. Quaternary Geochronology 10, 424-429. https://doi.org/10.1016/j.quageo.2012.02.013, 2012.

Bahnson, H., Petersen, K.S., Konradi, P. and Knudsen, K.L. (1974). Stratigraphy of Quaternary deposits in the Skaerumhede II boring: Lithology, molluscs and foraminifera. Danmarks Geologiske Unders6gelse, Arbog 1973, 27-62.

Balescu, S., and Haesaerts, P.: The Sangatte raised beach and the age of the opening of the Strait of Dover. Geologie en Mijnbouw 63(4), 355-362, 1984.

Balescu, S., and Lamothe, M.: The blue emission of K-feldspar coarse grains and its potential for overcoming TL age underestimation. Quaternary Science Reviews 11, 45-51. https://doi.org/10.1016/0277-3791(92)90041-6, 1992.

Balescu, S., Packman, S.C., and Wintle, A.G.: Chronological Separation of Interglacial Raised Beaches from Northwestern Europe Using Thermoluminescence. Quaternary Research 35, 91-102. https://doi.org/10.1016/0033-5894(91)90097-O, 1991.

Barlow, N. L. M., Shennan, I., Long, A. J., Gehrels, W. R., Saher, M. H., Woodroffe, S. A., and Hillier, C.: Salt marshes as geological tide gauges, Global and Planetary Change, 106, 90-110, 2013.

Barlow, N. L. M., Long, A. J., Gehrels, W. R., Saher, M. H., Scaife, R. G., Davies, H. J., Penkman, K. E. H., Bridgland, D. R., Sparkes, A., Smart, C. W., and Taylor, S.: Relative sea-level variability during the late Middle Pleistocene: new evidence from eastern England, Quaternary Science Reviews, 173, 20-39, 2017.

Barrois, C.: Note sur les traces de l'époque glaciaire en quelques points des côtes de Bretagne. Bulletin de la Société géologique de France 5, 535-537, 1877.

Barrois, C.: Sur les plages soulevées de la côte ouest du Finistère. Annales de la Société Géologique du Nord 9, 239-268, 1882.

Barrow, G.: The Geology of the Isles of Scilly. Memoirs of the Geological Survey, England and Wales, 1906.

Barthes, V., Pozzi, J. P., Vibert-Charbonnel, P., Thibal, J., and Melieres, M. A.: High-resolution chronostratigraphy from 1355 downhole susceptibility logging tuned by palaeoclimatic orbital frequencies. Earth and Planetary Science Letters, 165(1), 97-116, https://doi.org/10.1016/S0012-821X(98)00214-3, 1999.

Batchelor, C. L., Margold, M., Krapp, M., Murton, D. K., Dalton, A. S., Gibbard, P. L., Stokes, C. R., Murton, J. B., and Manica, A.: The configuration of Northern Hemisphere ice sheets through the Quaternary, Nat. Commun., 10, 37133713, https://doi.org/10.1038/s41467-019-11601-2, 2019.

1360 Bateman, M., and Catt, J.: An absolute chronology for the raised beach and associated deposits at Sewerby, East Yorkshire, England, Journal of Quaternary Science, 11, 389-395, https://doi.org/10.1002/(SICI)10991417(199609/10)11:5\%3C389::AID-JQS260\%3E3.0.CO;2-K, 1996. 
https://doi.org/10.5194/essd-2021-390

Preprint. Discussion started: 10 November 2021

(c) Author(s) 2021. CC BY 4.0 License.

(c) (i)

Bates, M.R., Parfitt, S.A., and Roberts, M.A.: The chronology, palaeogeography and archaeological significance of the marine Quaternary record of the West Sussex coastal plain, southern England, U.K. Quaternary Science Reviews, 16, 1227-1252, https://doi.org/10.1016/S0277-3791(96)00119-9, 1997.

Bates, M.R., Keen, D. H., and Lautridou, J.-P.: Pleistocene marine and periglacial deposits of the English Channel. Journal of Quaternary Science 18, 319-337. https://doi.org/10.1002/JQS.747, 2003.

Bates, M.R., Briant, R.M., Rhodes, E.J., Schwenninger, J.-L., and Whittaker, J.E.: A new chronological framework for Middle and Upper Pleistocene landscape evolution in the Sussex/Hampshire coastal corridor, UK. Proceedings of the Geologists' Association, 121, 369-392, https://doi.org/10.1016/j.pgeola.2010.02.004, 2010.

Bauch, H. A., Kandiano, E. S., Helmke, J., Andersen, N., Rosell-Mele, A., and Erlenkeuser, H.: Climatic bisection of the last interglacial warm period in the Polar North Atlantic, Quaternary Science Reviews, 30, 1813-1818, 2011.

Beets, C. J., and Beets, D. J.: A high resolution stable isotope record of the penultimate deglaciation in lake sediments below the city of Amsterdam, The Netherlands. Quaternary Science Reviews, 22(2-4), 195-207, https://doi.org/10.1016/S02773791(02)00089-6, 2003.

Beets, D. J., Meijer, T., Beets, C. J., Cleveringa, P., Laban, C., and Van der Spek, A. J. F.: Evidence for a Middle Pleistocene glaciation of MIS 8 age in the southern North Sea. Quaternary International, 133, 7-19, https://doi.org/10.1016/j.quaint.2004.10.002, 2005.

Beets, D. J., Beets, C. J., and Cleveringa, P.: Age and climate of the late Saalian and early Eemian in the type-area, Amsterdam basin, The Netherlands. Quaternary Science Reviews, 25(9-10), 876-885. https://doi.org/10.1016/j.quascirev.2005.10.001 2006.

Behre, K.E.: Pollen- und diatomeenanalytische Untersuchungen an letzinterglazialen Kieselgurlagen der Lueneburger Heide (Schwindebeck und Grevenhof im oberen Luhetal). Flora, 152, 325-370, 1962

Behre, K. E., Hölzer, A., and Lemdahl, G.: Botanical macro-remains and insects from the Eemian and Weichselian site of 1385 Oerel (northwest Germany) and their evidence for the history of climate. Vegetation history and archaeobotany, 14(1), 31-53, 2005.

Benda, L., and Schneekloth, H.: Das Eem-Interglazial von Koehlen, Krs. Wesermuende. Geologisches Jahrbuch 83, 699716, 1965.

Berendsen, H. J. A., Makaske, B., Van de Plassche, O., Van Ree, M. H. M., Das, S., Dongen, M. V., Ploumen, S. and Schoenmakers, W.. New groundwater-level rise data from the Rhine-Meuse delta-implications for the reconstruction of Holocene relative mean sea-level rise and differential land-level movements. Netherlands Journal of Geosciences/Geologie en Mijnbouw, 86(4), 333-354, 2007

Bigot, A.: Sur l'existence d'une station préhistorique à la Hougue (Manche). Mémoires de la Société nationale des sciences naturelles de Cherbourg XXV, 277-280, 1885.

1395 Bigot, A.: Les terrasses pléistocènes du littoral du Cotentin. Livre jubilaire de la Société géologique de France I, 133-148, 1930. 
Bogemans, F., Roe, H. M., and Baeteman, C.: Incised Pleistocene valleys in the Western Belgium coastal plain: Age, origins and implications for the evolution of the Southern North Sea Basin. Palaeogeography, Palaeoclimatology, Palaeoecology, 456, 46-59, 2016.

Bosch, J.H.A.: Toelichtingen bij de Geologische Kaart van Nederland 1:50 000. Blad Assen (12 W). Blad Assen (12 O), 1990.

Bowen, D.Q.: The Pleistocene succession of the Irish Sea. Proceedings of the Geologists' Association, 84, 249-272, 1973.

Bowen, D.Q., Sykes, G.A., Reeves, A., Miller, G.H., Andrews, J.T., Brew, J.S., and Hare, P.E.: Amino acid geochronology of raised beaches in south west Britain. Quaternary Science Reviews, 4, 279-318, 1985.

Bradley, S. L., Milne, G. A., Shennan, I., and Edwards, R.: An improved glacial isostatic adjustment model for the British Isles, Journal of Quaternary Science, 26, 541-552, 10.1002/jqs.1481, 2011.

Bradshaw, E., Woodworth, P. L., Hibbert, A., Bradley, L. J., Pugh, D. T., Fane, C., and Bingley, R. M.: A Century of Sea Level Measurements at Newlyn, Southwest England, Marine Geodesy, 39, 115-140, 10.1080/01490419.2015.1121175, 2016.

Brain, M. J.: Compaction, in: Handbook of sea-level research, edited by: Shennan, I., Long, A. J., and Horton, B. P., John Wiley \& Sons, Ltd, Chichester, UK, 452-469, 2015.

Breton, G., Cousin, R., Huault, M.-F., Lechevallier, C., and Lefebvre, D.: Les sédiments quaternaires du quartier de l'Hotel de Ville, au Havre: séquences marines pré-éemienne, éemienne et holocène de l'estuaire de la Seine. Bulletin de la Société Géologique de Normandie 4, 15-63, 1991.

1415 Briant, R.M., Bates, M.R., Schwenninger, J-L., and Wenban-Smith, F.: An optically stimulated luminescence date Middle to Late Pleistocene fluvial sequence from the western Solent Basin, southern England. Journal of Quaternary Science, 21(5), 507-523, https://doi.org/10.1002/jqs.1035, 2006.

Briant, R. M., Kilfeather, A., Parfitt, S., Penkman, K., Preece, R., Roe, H., Schwenninger, J.-L., Wenban-Smith, F., and Whittaker, J.: Integrated chronological control on an archaeologically significant Pleistocene river terrace sequence: the Thames-Medway, eastern Essex, England, Proceedings of the Geologists' Association, 123, 87-108, https://doi.org/10.1016/j.pgeola.2011.07.008, 2012.

Briant, R.M., Bates, M.R., Boreham, S., Cameron, N.G., Coope, G.R., Field, M.H., Hatch, B.M., Holmes, J.A., Keen, D.H., Kilfeather, A.A., Penkman, K.E.H., Simons, R.M.J., Schwenninger, J-L., Wenban-Smith, F.F., Whitehouse N.J., and Whittaker, J.E.: Early Ipswichian (last interglacial) sea level rise in the channel region: Stone Point Site of Special Scientific Interest, Hampshire, England. Proceedings of the Geologists' Association, 130, 1-26, https://doi.org/10.1016/j.pgeola.2018.03.002, 2019.

Bridgland, D. R.: Quaternary of the Thames, Joint Nature Conservation Committee. Chapman \& Hall, London, 1994.

Bridgland, D. R., and d'Olier, B.: The Pleistocene evolution of the Thames and Rhine drainage systems in the southern North Sea Basin. Geological Society, London, Special Publications, 96(1), 27-45, 1995. 
https://doi.org/10.5194/essd-2021-390

Preprint. Discussion started: 10 November 2021

(c) Author(s) 2021. CC BY 4.0 License.

(c) (i)

1430 Bridgland, D., Currant, A., and Preece, R.: East Mersea restaurant site (TM 053136), in: The Quaternary of the Lower Reaches of the Thames: Field Guide, edited by: Bridgland, D. R., Allen, P., and Haggart, B. A., Quaternary Research Association, London, 271-274, 1995a.

Bridgland, D. R., Keen, D. H., Green, G. P., Bowen, D. Q., and Sykes, G. A.: Last Interglacial deposits at Folkestone, Kent, Proceedings of the Geologists' Association, 106, 183-193, 1995b.

1435 Bronk Ramsey, C.: Deposition models for chronological records. Quaternary Science Reviews, 27(1-2), 42-60, 2008.

Bungenstock, F., Freund, H., and Bartholomä, A.: Holocene relative sea-level data for the East Frisian barrier coast, NW Germany, southern North Sea, Netherlands Journal of Geosciences, 100, E16. doi:10.1017/njg.2021.11, 2021

Busschers, F. S., Weerts, H. J. T., Wallinga, J., Cleveringa, P., Kasse, C., De Wolf, H., and Cohen, K. M.: Sedimentary architecture and optical dating of Middle and Late Pleistocene Rhine-Meuse deposits-fluvial response to climate change, sea-level fluctuation and glaciation, Netherlands Journal of Geosciences, 84(1), 25-41, 2005.

Busschers, F. S., Kasse, C., Van Balen, R. T., Vandenberghe, J., Cohen, K. M., Weerts, H. J. T., Wallinga, J., Johns, C., Cleveringa, P., and Bunnik, F. P. M.: Late Pleistocene evolution of the Rhine-Meuse system in the southern North Sea basin: imprints of climate change, sea-level oscillation and glacio-isostacy, Quaternary Science Reviews, 26(25-28), 3216-3248, 2007.

1445 Busschers, F. S., Van Balen, R. T., Cohen, K. M., Kasse, C., Weerts, H. J., Wallinga, J., and Bunnik, F. P.: Response of the Rhine-Meuse fluvial system to Saalian ice-sheet dynamics, Boreas, 37(3), 377-398, https://doi.org/10.1111/j.1502$\underline{3885.2008 .00025 . x}, 2008$

Buylaert, J. P., Huot, S., Murray, A. S., and Van Den Haute, P.: Infrared stimulated luminescence dating of an Eemian (MIS 5e) site in Denmark using K-feldspar. Boreas, 40(1), 46-56, https://doi.org/10.1111/j.1502-3885.2010.00156.x, 2011.

1450 Campbell, S., Andrews, J.T., and Shakesby, R.A.: Amino acid evidence for Devensian ice, west Gower, South Wales. Nature, 300, 249-251, 1982.

Campbell, S., Hunt, C.O., Scourse, J.D., and Keen, D.H.: Quaternary of South-west England. Chapman \& Hall, London, 1998.

Candy, I., White, T. S., and Elias, S.: How warm was Britain during the Last Interglacial? A critical review of Ipswichian 1455 (MIS 5e) palaeotemperature reconstructions, Journal of Quaternary Science, 31, 857-868, https://doi.org/10.1002/jqs.2910, 2016.

Cartelle, V., Barlow, N. L., Hodgson, D. M., Busschers, F. S., Cohen, K. M., Meijninger, B. M., and Van Kesteren, W. P.: Sedimentary architecture and landforms of the Late Saalian (MIS 6) ice sheet margin, offshore the Netherlands. Earth Surface Dynamics Discussions, 2021, 1-40, 2021.

1460 Catt, J. A., and Penny, L. F.: The Pleistocene Deposits of Holderness, East Yorkshire, Proceedings of the Yorkshire Geological Society, Proc. 35(3), 375-409, https://doi.org/10.1144/pygs.35.3.375, 1966.

Catt, J.: The Pleistocene glaciations of eastern Yorkshire: a review, Proceedings of the Yorkshire Geological Society, 56, 177-207, 2007. 
https://doi.org/10.5194/essd-2021-390

Preprint. Discussion started: 10 November 2021

(c) Author(s) 2021. CC BY 4.0 License.

(c) (i)

Chutcharavan, P. M., and Dutton, A.: A global compilation of U-series-dated fossil coral sea-level indicators for the Last Interglacial period (Marine Isotope Stage 5e), Earth Syst. Sci. Data, 13, 3155-3178, 10.5194/essd-13-3155-2021, 2021.

Clemmensen, L. B., Hougaard, I. W., Murray, A. S., and Pedersen, S. S.: A high-resolution sea-level proxy dated using quartz OSL from the Holocene Skagen Odde spit system, Denmark. Boreas, 47(4), 1184-1198, 2018.

Clemmensen, L. B., Richardt, N., and Andersen, C.: Holocene sea-level variation and spit development: data from Skagen Odde, Denmark. The Holocene, 11(3), 323-331, 2001.

1470 Cleveringa, P., Meijer, T., Van Leeuwen, R. J. W., Wolf, H. D., Pouwer, R., Lissenberg, T., and Burger, A. W.: The Eemian stratotype locality at Amersfoort in the central Netherlands: a re-evaluation of old and new data. Netherlands Journal of Geosciences/Geologie en Mijnbouw, 79(2/3), https://doi.org/10.1017/S0016774600023659, 2000.

Cliquet, D., Mercier, N., Valladas, H., Froget, L., Michel, D., van Vliet-Lanoë, B., and Vilgrain, G.: Apport de la thermoluminescence sur silex chauffes à la chronologie de site paléolithiques de Normandie: nouvelles données et interprétations. Quaternaire 14, 51-64. https://doi.org/10.3406/quate.2003.1729, 2003.

Cliquet, D., Lautridou, J.-P., Lamothe, M., Mercier, N., Schwenninger, J.-L., Alix, P., and Vilgrain, G.: Nouvelles données sur le site majeur d'Écalgrain: datations radiométriques et occupations humaines de la Pointe de la Hague (Cotentin, Normandie). Quaternaire 20, 345-359. https://doi.org/10.4000/quaternaire.5244, 2009.

Cliquet, D.: Le gisement paléolithique moyen de Saint-Germain des Vaux/Port-Racine (Manche) dans son cadre régional. 1480 Editions ERAUL, Liège, 1992.

Cohen, K. M., and Gibbard, P. L.: Global chronostratigraphical correlation table for the last 2.7 million years, version 2019 QI-500. Quaternary International, 500, 20-31, 2019.

Cohen, K. M., MacDonald, K., Joordens, J. C. A., Roebroeks, W., and Gibbard, P. L.: The earliest occupation of north-west Europe: a coastal perspective, Quaternary International, 271, 70-83, https://doi.org/10.1016/j.quaint.2011.11.003, 2012.

1485 Cohen, K. M., Gibbard, P. L., and Weerts, H. J. T.: North Sea palaeogeographical reconstructions for the last 1 Ma. Netherlands Journal of Geosciences, 93(1-2), 7-29, 2014.

Cohen, K. M., Westley, K., Erkens, G., Hijma, M. P., and Weerts, H. J. T.: The North Sea, in: Submerged landscapes of the European continental shelf: quaternary paleoenvironments. Wiley, Chichester, 147-186, 2017.

Cohen, K.M., Cartelle, V., Barnett, R., Busschers, F.S., and Barlow, N.L.M.: Last Interglacial sea-level data points from 1490 Northwest Europe [data set], https://doi.org/10.5281/zenodo.5608459, 2021.

Coutard, S., Lautridou, J.-P., and Rhodes, E.: Discontinuités dans l'enregistrement des cycles interglaciaire-glaciaire sur un littoral en contexte intraplaque. Exemple du Val de Saire (Normandie, France). Quaternaire 16, 217-227. https://doi.org/10.4000/quaternaire.434, 2005.

Coutard, S., Lautridou, J.P., Rhodes, E., and Clet, M.: Tectonic, eustatic and climatic significance of raised beaches of Val 1495 de Saire, Cotentin, Normandy, France. Quaternary Science Reviews 25, 595-611. https://doi.org/10.1016/j.quascirev.2005.02.003, 2006. 
Dalton, A.S., Gowan, E.J., Mangerud, J., Möller, P.. Lunkka, J.P., and Astakhov, V.: Last interglacial (MIS 5e) sea level proxies in the glaciated Northern Hemisphere [data set]. https://doi.org/10.5281/zenodo.5602213, 2021.

Davies, K.H.: Amino acid analysis of Pleistocene marine molluscs from the Gower Peninsula. Nature, 32, 137-139, 1983.

Davies, K.H.: The aminostratigraphy of British Pleistocene beach deposits. Unpublished PhD Thesis. U.C.W. Aberystwyth, 1984.

Davies, K.H., and Keen, D.H.: The age of Pleistocene marine deposits at Portland, Dorset. Proceedings of the Geologists' Association, 96, 217-225, 1985.

De Clercq, M., Missiaen, T., Wallinga, J., Zurita Hurtado, O., Versendaal, A., Mathys, M., and De Batist, M.: A wellpreserved Eemian incised-valley fill in the southern North Sea Basin, Belgian Continental Shelf-Coastal Plain: Implications for northwest European landscape evolution. Earth Surface Processes and Landforms, 43(9), 1913-1942, https://doi.org/10.1002/esp.4365, 2018.

De Gans, W., Beets, D. J., and Centineo, M. C.. Late Saalian and Eemian deposits in the Amsterdam glacial basin. Netherlands Journal of Geosciences, 79(2-3), 147-160, https://doi.org/10.1017/S0016774600021685, 2000.

1510 De Heinzelin, J.: Falaise et plage suspendue de Sangatte. Bulletin de la Société Belge de Géologie 75, 292-296., 1966.

De La Beche, H.T.: Report on the geology of Cornwall and Devon and West Somerset. Memoirs of the Geological Survey. London, 1839.

De Moor, G., and De Breuck, W.: Sedimentologie en stratigrafie van enkele pleistocene afzettingen in de Belgische kustvlakte. Natuurwetenschappelijk Tijdschrift 55, 3-96, 1973.

1515 De Moor, G, and Pissart A.: Het reliëf, in: Geografie van België, Denis, J. (ed.), Gemeentekrediet, Brussels. pp. 128-215, 1992.

Demarchi, B., Williams, M. G., Milner, N., Russell, N., Bailey, G., and Penkman, K.: Amino acid racemization dating of marine shells: A mound of possibilities, Quaternary International, 239, 114-124, https://doi.org/10.1016/j.quaint.2010.05.029, 2011.

Dendy, S., Austermann, J., Creveling, J. R., and Mitrovica, J. X.: Sensitivity of Last Interglacial sea-level high stands to ice sheet configuration during Marine Isotope Stage 6, Quaternary Science Reviews, 171, 234-244, https://doi.org/10.1016/j.quascirev.2017.06.013, 2017.

Dixon, F.: The Geology and Fossils of the Tertiary and Cretaceous Formations of Sussex, Longman, Brown, Green and Longmans, 1850.

Düsterhus, A., Tamisiea, M. E., and Jevrejeva, S.: Estimating the sea level highstand during the last interglacial: a probabilistic massive ensemble approach, Geophysical Journal International, 206, 900-920, https://doi.org/10.1093/gji/ggw174, 2016.

Dutton, A., Carlson, A. E., Long, A. J., Milne, G. A., Clark, P. U., DeConto, R., Horton, B. P., Rahmstorf, S., and Raymo, M. E.: Sea-level rise due to polar ice-sheet mass loss during past warm periods, Science, 349, https://doi.org/10.1126/science.aaa4019, 2015. 
Eaton, S. J., Hodgson, D. M., Barlow, N. L., Mortimer, E. E., and Mellett, C. L.: Palaeogeographical changes in response to glacial-interglacial cycles, as recorded in Middle and Late Pleistocene seismic stratigraphy, southern North Sea, Journal of Quaternary Science, 35, 760-775, 2020.

Edwards, R. J., and Horton, B. P.: Reconstructing relative sea-level change using UK salt-marsh foraminifera, Marine Geology, 169, 41-56, https://doi.org/10.1016/s0025-3227(00)00078-5, 2000.

Ehlers, J., and Gibbard, P. L.: Quaternary glaciations-extent and chronology: part I: Europe. Elsevier, 2004.

Ehlers, J., Eissman, L., Lippstreu, L., Stephan, H. J., and Wansa, S.: Pleistocene glaciations of north Germany. Quaternary Glaciations-Extent and Chronology: Part I: Europe, 135. Ehlers et al., 2004; https://doi.org/10.1016/S15710866(04)80064-2, 2004.

1540 Elhaï, H.: La Normandie occidentale entre la Seine et le Golfe normand-breton. Etude morphologique. Imprimerie Bière, Bodeaux, 1963.

EMODnet Bathymetry Consortium: EMODnet Digital Bathymetry (DTM). https://doi.org/10.12770/bb6a87dd-e579-4036abe1-e649cea9881a, 2020.

Engelhart, S. E., and Horton, B. P.: Holocene sea level database for the Atlantic coast of the United States, Quaternary Science Reviews, 54, 12-25, http://dx.doi.org/10.1016/j.quascirev.2011.09.013, 2012.

Engelhart, S. E., Horton, B. P., and Kemp, A. C.: Holocene Sea Level Changes Along the United States' Atlantic Coast, Oceanography, 24, 70-79, https://doi.org/10.1016/j.quascirev.2011.09.013, 2011.

Farrell, W. E., and Clark, J. A.: On postglacial sea level, Geophysical Journal of the Royal Astronomical Society, 46, 647$667,1976$.

1550 Flemming, N. C.: Multiple regression analysis of earth movements and eustatic sea-level change in the United Kingdom in the past 9000 years, Proceedings of the Geologists' Association, 93, 113-125, https://doi.org/10.1016/S00167878(82)80035-7, 1982.

Folz, E.: La luminescence stimulée optiquement du quartz: développements méthodologiques et applications à la datation de séquences du pléistocène supérieur du nord-ouest de la France, 2000.

1555 Franks, J. W.: Interglacial deposits at Trafalgar Square, London, New Phytologist, 59, 145-152, https://doi.org/10.1111/j.1469-8137.1960.tb06212.x, 1960.

Friborg, R.: The landscape below the Tinglev outwash plain: a reconstruction, Bulletin of the Geological Society of Denmark 43, 34-40, 1996.

Funder, S., Demidov, I., and Yelovicheva, Y.: Hydrography and mollusc faunas of the Baltic and the White Sea-North Sea seaway in the Eemian, Palaeogeography, Palaeoclimatology, Palaeoecology, 184(3-4), 275-304, https://doi.org/10.1016/S0031-0182(02)00256-0, 2002.

García-Moreno, D., Verbeeck, K., Camelbeeck, T., De Batist, M., Oggioni, F., Zurita Hurtado, O., Versteeg, W., Jomard, H., Collier, J. S., Gupta, S., Trentesaux, A., and Vanneste, K.. Fault activity in the epicentral area of the 1580 Dover Strait 
https://doi.org/10.5194/essd-2021-390

Preprint. Discussion started: 10 November 2021

(c) Author(s) 2021. CC BY 4.0 License.

(Pas-de-Calais) earthquake (northwestern Europe). Geophysical Journal International, 201(2), 528-542, http://doi.org/10.1093/gji/ggv041, 2015.

Gale, S.J., Hoare, P.G., Hunt, C.O. and Pye, K.: The middle and upper Quaternary deposits at Morton, North Norfolk, UK. Geological Magazine, 125(5), 521-533, https://doi.org/10.1017/S001675680001325X, 1988

Garzon, S., and Rovere, A.: WALIS visualization interface (Version 1.0) [ software ] https://doi.org/10.5281/zenodo.4943541, 2021

1570 Gehrels, W. R.: Determining relative sea-level change from salt-marsh foraminifera and plant zones on the coast of Maine, USA, Journal of Coastal Research, 10, 990-1009, 1994.

Gehrels, W. R.: Using foraminiferal transfer functions to produce high-resloution sea-level records from salt-marsh deposits, Maine, USA., The Holocene, 10, 367-376, 2000.

Gibbard, P. L.: The Pleistocene history of the Middle Thames valley, Cambridge University Press, 1985.

Gibbard, P.L.: The history of the great northwest European rivers during the past three million years. Philosophical Transactions of the Royal Society of London. Series B, Biological Sciences 318: 559-602, 1988.

Gibbard, P. L.: The formation of the Strait of Dover. Geological Society, London, Special Publications, 96(1), 15-26, 1995.

Gibbard, P. L., West, R. G., and Hughes, P. D.: Pleistocene glaciation of Fenland, England, and its implications for evolution of the region. Royal Society Open Science, 5(1), 170736, https://doi.org/10.1098/rsos.170736, 2018.

1580 Gilbert, A.: The raised shoreline sequence at Saunton. In: Devon and East Cornwall, Charman, D.J., Newnham, R.M., Croot, D. (eds.). Field Guide, Quaternary Research Association, London, 40-47, 1996.

Godwin-Austen, R.: On the land-surfaces beneath the Drift-Gravel. Journal of the Geological Society of London, 11, 112$119,1855$.

Godwin-Austen, R.: On the Newer Tertiary Deposits of the Sussex Coast. Quarterly Journal of the Geological Society of 1585 London, 13, 40-72, 1857.

Greensmith, J.T., and Tucker, E.V.: Compaction and consolidation. 1986

Grüger, E.: Palynostratigraphy of the last interglacial/glacial cycle in Germany. Quaternary International, 3, 69-79, 1989.

Gupta, S., Collier, J. S., Palmer-Felgate, A., and Potter, G.: Catastrophic flooding origin of shelf valley systems in the English Channel. Nature, 448(7151), 342-345, https://doi.org/10.1038/nature06018, 2007.

1590 Guilcher, A., and B. Hallegouet : Le haut cordon de galets Pleistocene de Ruvein en Plovan (Finistere) et ses enseignements generaux: Bulletin de l'Association Francaise pour l'Etude du Quaternaire, v. 18 (2), 75-82, https://doi.org/10.3406/quate.1981.1410, 1981.

Haesaerts, P., and Dupuis, C.: Contribution à la stratigraphie des nappes alluviales de la Somme et de l'Avre dans la région d'Amiens. Supplément au Bulletin de l'Association Française pour l'Etude du Quaternaire 26, 171-186,1986.

1595 Hanebuth, T., Stattegger, K., and Grootes, P. M.: Rapid flooding of the Sunda Shelf: a late-glacial sea-level record. Science, 288(5468), 1033-1035, 2000. 
https://doi.org/10.5194/essd-2021-390

Preprint. Discussion started: 10 November 2021

(c) Author(s) 2021. CC BY 4.0 License.

(c) (i)

Hansen, S.: The Quaternary of Denmark. In: Rankama, K. (ed.), The Geologic Systems: The Quaternary, Vol. 1, pp. 1-90, Interscience Publishers, Wiley and Sons, 1965.

Harting, P.: De bodem van het Eemdal. Verslagen en Verhandelingen Koninklijke Academie van Wetenschappen, 2e Reeks 8: $282-2901874$

Haslett, S.K., and Curr, R.H.F.; Stratigraphy and palaeoenvironmental development of Quaternary coarse clastic beach deposits at Plage de Mezpeurleuch, Brittany (France). Geological Journal 36, 171-182, https://doi.org/10.1002/GJ.888, 2001.

Hay, C., Mitrovica, J. X., Gomez, N., Creveling, J. R., Austermann, J., and E. Kopp, R.: The sea-level fingerprints of icesheet collapse during interglacial periods, Quaternary Science Reviews, 87, 60-69, https://doi.org/10.1016/j.quascirev.2013.12.022, 2014.

Helmens, K. F., Salonen, J. S., Plikk, A., Engels, S., Väliranta, M., Kylander, M., Brendryen, J., and Renssen, H.: Major cooling intersecting peak Eemian Interglacial warmth in northern Europe, Quaternary Science Reviews, 122, 293-299, https://doi.org/10.1016/j.quascirev.2015.05.018, 2015

Heyse, I.: Bijdrage tot de Geomorfologische Kennis van het Noordwesten van Oost-Vlaanderen (Belgie), Verhandelingen van de Koninklijke Academie voor Wetenschappen, Letteren en Schone Kunsten van Belgie, Klasse der Wetenschappen, Jaargang XLI, Vol. 155, 1979.

Hijma, M. P., and Cohen, K. M.: Holocene transgression of the Rhine river mouth area, The Netherlands/Southern North Sea: palaeogeography and sequence stratigraphy. Sedimentology, 58(6), 1453-1485, 2011.

Hijma, M. P., and Cohen, K. M.: Holocene sea-level database for the Rhine-Meuse Delta, The Netherlands: Implications for the pre-8.2 ka sea-level jump, Quaternary Science Reviews, 214, 68-86, https://doi.org/10.1016/j.quascirev.2019.05.001, 2019.

Hijma, M. P., Cohen, K. M., Hoffmann, G., Van der Spek, A. J., and Stouthamer, E.: From river valley to estuary: the evolution of the Rhine mouth in the early to middle Holocene (western Netherlands, Rhine-Meuse delta). Netherlands Journal of Geosciences, 88(1), 13-53, 2009.

Hijma, M. P., Cohen, K. M., Roebroeks, W., Westerhoff, W. E., \& Busschers, F. S.: Pleistocene Rhine-Thames landscapes: geological background for hominin occupation of the southern North Sea region. Journal of Quaternary Science, 27(1), 17-39, https://doi.org/10.1002/jqs.1549, 2012.

Hijma, M., Engelhart, S. E., Törnqvist, T. E., Horton, B. P., Hu, P., and Hill, D. F.: A protocol for a geological sea-level database, in: Handbook of sea-level research, edited by: Shennan, I., Long, A. J., and Horton, B. P., John Wiley \& Sons, Ltd, Chichester, UK, 536-553, 2015.

Hinton, M. A. C., and Kennard, A. S.: Contributions to the Pleistocene geology of the Thames Valley. 1. The GraysThurrock area, part 1, Essex Naturalist, 11, 226-270, 1901.

Hodgson, J.M.: The low-level Pleistocene marine sands and gravels of the West Sussex Coastal Plain. Proceedings of the Geologists' Association, 75, 547-562, 1964. 
https://doi.org/10.5194/essd-2021-390

Preprint. Discussion started: 10 November 2021

(c) Author(s) 2021. CC BY 4.0 License.

(c) (i)

Holgate, S. J., Matthews, A., Woodworth, P. L., Rickards, L. J., Tamisiea, M. E., Bradshaw, E., Foden, P.R.; Gordon, K.M.; Jevrejeva, S., and Pugh, J.: New data systems and products at the permanent service for mean sea level, Journal of Coastal Research, 29(3), 493-504, https://doi.org/10.2112/jcoastres-d-12-00175.1, 2013.

Hollin, J. T.: Thames interglacial sites, Ipswichian sea levels and Antarctic ice surges, Boreas, 6, 33-52, https://doi.org/10.1002/jqs.3390080407, 1977.

Holyoak, D. T., and Preece, R. C.: Late Pleistocene Interglacial Deposits at Tattershall, Lincolnshire, Philosophical Transactions of the Royal Society of London. Series B, Biological Sciences, 311, 193-236, 1985.

Houmark-Nielsen, M.: Pleistocene stratigraphy and glacial history of the central part of Denmark. Bulletin Geological Society of Denmark, 1987.

1640 James, H.C.L.: An examination of recently exposed Pleistocene sections at Godrevy. Proceedings of the Ussher Society, 3(2), 299-301, 1975.

James, H.C.L.: Aspects of the raised beaches of South Cornwall. Proceedings of the Ussher Society, 2, 55-56, 1968.

James, H.C.L.: Raised beaches of West Cornwall and their evolving geochronology. Proceedings of the Ussher Society, 8, 437-440, 1995.

1645 James, H.C.L.: An extension of the well-known Quaternary section at Godrevy, St Ives Bay, West Cornwall: Analysis and review. Geoscience in South-West England, 12, 55-57, 2008.

Jelgersma, S.: Post-glacial rise of sea-level in the Netherlands (a preliminary report). Geologie en Mijnbouw, 39(22), 201207, 1960.

Jelgersma, S.: Sea-level changes in the North Sea basin, in: The Quaternary history of the North Sea. Symposia Universitatis Upsaliensis annum quingen-tesimum celebrantis, Vol. 2, 238-248, 1979.

Jessen, A., Milthers, V., Nordmann, V., Hartz, N. and Hesselboe, A. (1910). En Boring gennem de Kvartaere Lag ved Skaerumhede. Danmarks Geologiske Unders6gelse Raekke II, 25, 175 pp.

Jessen, K., and Milthers, V.: Stratigraphical and palaeontological studies of interglacial fresh-water deposits in Jutland and northwest Germany. Danmarks Geologiske Undersogelse Series 2, 48, 1-379, 1928.

1655 Keen, D.H., Harmon, R.S., and Andrews, J.T.: U-series and amino acid dates from Jersey. Nature, 289, 162-164, https://doi.org/10.1038/289162a0, 1981.

Kiden, P., Denys, L., and Johnston, P.: Late Quaternary sea-level change and isostatic and tectonic land movements along the Belgian-Dutch North Sea coast: geological data and model results. Journal of Quaternary Science, 17(5-6), 535-546, https://doi.org/10.1002/jqs.709, 2002

1660 Kidson, C., and Heyworth, A.: The Quaternary deposits of the Somerset Levels, 9, 217-235, 10.1144/GSL.QJEG.1976.009.03.05 \%J Quarterly Journal of Engineering Geology and Hydrogeology, 1976.

Knudsen, K.-L.: Foraminiferal faunas in Eemian deposits of the Oldenbüttel area near the Kiel Canal, Germany. Geol. Jb., A86: 27-47, 1985. 
https://doi.org/10.5194/essd-2021-390

Preprint. Discussion started: 10 November 2021

(c) Author(s) 2021. CC BY 4.0 License.

(c) (i)

Knudsen, K.L. and Lykke-Andersen, A.-L.: Foraminifera in Late Saalian, Eemian, Early and Middle Weichselian of the Skaerumhede I boring. Bulletin Geological Society Denmark, 30, 97-109, 1982.

Knudsen, K. L., Kristensen, P., and Larsen, N. K.: Marine glacial and interglacial stratigraphy in Vendsyssel, northern Denmark: foraminifera and stable isotopes. Boreas, 38(4), 787-810, 2009.

Konradi, P.B.: Foraminifera in Eemian deposits at Stensigmose, southern Jutland. Danmarks Geologiske Undersokelse Raekke H, 105, 57 pp, 1976.

1670 Konradi, P. B., Larsen, B., and Sørensen, A. B.: Marine Eemian in the Danish eastern North Sea. Quaternary International, 133, 21-31, https://doi.org/10.1016/j.quaint.2004.10.003, 2005.

Kooi, H., Johnston, P., Lambeck, K., Smither, C., and Molendijk, R.: Geological causes of recent ( $100 \mathrm{yr})$ vertical land movement in the Netherlands. Tectonophysics, 299(4), 297-316, https://doi.org/10.1016/S0040-1951(98)00209-1, 1998.

Kopp, R. E., Simons, F. J., Mitrovica, J. X., Maloof, A. C., and Oppenheimer, M.: Probabilistic assessment of sea level 1675 during the last interglacial stage, Nature, 462, 863-867, https://doi.org/10.1038/nature08686, 2009.

Kosack, B., and Lange, W.: Das Eem-Vorkommen von Offenbüttel/Schnittlohe und die Ausbreitung des Eem-Meeres zwischen Nord-und Ostsee. Geologisches Jahrbuch. Reihe A, Allgemeine und regionale Geologie BR Deutschland und Nachbargebiete, Tektonik, Stratigraphie, Paläontologie, (86), 3-17, 1985.

Kristensen, P., Gibbard, P., Knudsen, K. L., and Ehlers, J.: Last interglacial stratigraphy at Ristinge Klint, south Denmark. Boreas, 29, 103-116, https://doi.org/10.1111/j.1502-3885.2000.tb01204.x, 2000.

Kubisch, M., and Schönfeld, J.: Eine neue "Cyprinen-Ton"-Scholle bei Stohl (Schleswig-Holstein): Mikrofauna und Grobfraktionsanalyse von Sedimenten der Eemzeitlichen Ostsee. Meyniana, 37, 89-95, 1985.

Kühl, N., Litt, T., Schölzel, C., \& Hense, A. (2007). Eemian and Early Weichselian temperature and precipitation variability in northern Germany. Quaternary Science Reviews, 26(25-28), 3311-3317.

1685 Kuhlmann, G., Langereis, C., Munsterman, D., van Leeuwen, R. J., Verreussel, R., Meulenkamp, J., and Wong, T.: Chronostratigraphy of Late Neogene sediments in the southern North Sea Basin and paleoenvironmental interpretations. Palaeogeography, Palaeoclimatology, Palaeoecology, 239(3-4), 426-455, https://doi.org/10.1016/j.palaeo.2006.02.004, 2006a.

. Kuhlmann, G., Langereis, C. G., Munsterman, D., Van Leeuwen, R. J., Verreussel, R., Meulenkamp, J. E., and Wong, T. E. 1690 (2006). Integrated chronostratigraphy of the Pliocene-Pleistocene interval and its relation to the regional stratigraphical stages in the southern North Sea region. Netherlands Journal of Geosciences, 85(1), 19-35, https://doi.org/10.1017/S0016774600021405, 2006b.

Kukla, G. J., Bender, M. L., de Beaulieu, J. L., Bond, G., Broecker, W. S., Cleveringa, P., Gavin, J.E., Herbert, T.D., Imbrie, J., Jouzel, J., Keigwin, L.D., Knudsen, K.-L., McManus, J.F., Merkt, J., Muhs, D.R., Müller, Poore, R.Z., Porter, S.C., 1695 Seret, G., Shackleton, N.J., Turner, Ch., and Tzedakis, P.C : Last Interglacial Climates. Quaternary Research, 58(1), 213, https://doi.org/10.1006/qres.2001.2316, 2002. 
Lamb, R. M., Harding, R., Huuse, M., Stewart, M., and Brocklehurst, S. H.: The early Quaternary North Sea Basin. Journal of the Geological Society, 175(2), 275-290, https://doi.org/10.1144/jgs2017-057, 2018.

Lambeck, K.: Late Devensian And Holocene Shorelines Of The British-Isles And North-Sea From Models Of GlacioHydro-Isostatic Rebound, J. Geol. Soc., 152, 437-448, 1995.

Lambeck, K., Purcell, A., Funder, S., KjæR, K. H., Larsen, E., and Moller, P. E. R.: Constraints on the Late Saalian to early Middle Weichselian ice sheet of Eurasia from field data and rebound modelling, Boreas, 35, 539-575, https://doi.org/10.1080/03009480600781875, 2006.

Lamplugh, G. W.: On the Bridlington and Dimlington Glacial Shell-beds, Geological Magazine, 8, 535-546, , https://doi.org/10.1017/S0016756800159229, 1881.

Lamplugh, G. W.: Report on the buried cliff at Sewerby, near Bridlington, Proceedings of the Yorkshire Geological and Polytechnic Society, 381-392, https://doi.org/10.1144/pygs.15.1.91, 1887.

Lang, J., Lauer, T., and Winsemann, J.: New age constraints for the Saalian glaciation in northern central Europe: Implications for the extent of ice sheets and related proglacial lake systems. Quaternary Science Reviews, 180, 240-259, 2018.

Larsen, N. K., Krohn, C. F., Kronborg, C., Nielsen, O. B., and Knudsen, K. L.: Lithostratigraphy of the late Saalian to middle Weichselian Skaerumhede Group in Vendsyssel, northern Denmark. Boreas, 38(4), 762-786, https://doi.org/10.1111/j.1502-3885.2009.00102.x, 2009.

Lautridou, J.-P., and Cliquet, D.: Le Pléistocène supérieur de Normandie et peuplements préhistoriques. Quaternaire 17, 187-206. https://doi.org/10.4000/quaternaire.815, 2006.

Lautridou, J.-P., Baize, S., Clet, M., Coutard, J.-P., and Ozouf, J.-C.: Les séquences plio-pléistocènes littorales et estuariennes de Normandie. Quaternaire 10, 161-169, 1999.

Lautridou, J.-P., Auguste, P., Carpentier, G., Cordy, J.-M., Lebret, P., Lechevalier, C., and Lefebvre, D.: L'Eemien et le Pléistocène moyen récent fluvio-marin et continental de la vallée de la Seine de Cléon au Havre (Normandie). Quaternaire 14, 25-30. https://doi.org/10.3406/quate.2003.1726, 2003.

Lewis, S., G., Ashton, N., and Jacobi, R.: 9 - Testing Human Presence During the Last Interglacial (MIS 5e): A Review of the British Evidence, in: Developments in Quaternary Sciences, edited by: Ashton, N., Lewis, S. G., and Stringer, C., Elsevier, 125-164, 2011.

Lisiecki, L. E., and Raymo, M. E.: A Pliocene-Pleistocene stack of 57 globally distributed benthic $\delta 180$ records, Paleoceanography 20(1), 2005.

Long, A. J., Woodroffe, S. A., Roberts, D. H., and Dawson, S.: Isolation basins, sea-level changes and the Holocene history of the Greenland Ice Sheet, Quaternary Science Reviews, 30, 3748-3768, https://doi.org/10.1016/j.quascirev.2011.10.013, 2011. 
Long, A. J., Barlow, N. L. M., Busschers, F. S., Cohen, K. M., Gehrels, W. R., and Wake, L. M.: Near-field sea-level variability in northwest Europe and ice sheet stability during the last interglacial, Quaternary Science Reviews, 126, 2640, http://doi.org/10.1016/j.quascirev.2015.08.021 , 2015.

Lorié, J.: De Geologische Bouw der Gelderse Vallei, benevens Beschrijving van eenige nieuwe grondboringen. VII - Verh. Kon. Akad. Wetensch. 2-12-1: 1-100. 1906.

Loyer, S., van Vliet-Lanoë, B., Monnier, J.L., Hallegouet, B., and Mercier, N.: La coupe de Nantois (Baie de Saint-Brieuc, 1735 France): Datations par thermoluminescence (TL) et données paléoenvironnementales nouvelles pour le Pléistocène de Bretagne. Quaternaire 6, 21-33. https://doi.org/10.3406/quate.1995.2034, 1995.

Mackie, S.J.: On a deposit at Folkestone containing bones of Mammalia. Quarterly Journal of the Geological Society of London, VII, 257-262, 1851.

Madsen, V. C., Nordmann, V. J. H., and Hartz, N. E. K.: Eem-zonerne: Studier over Cyprinaleret og andre Eem-aflejringer i Danmark, Nord-Tyskland og Holland. Danmarks Geologiske Undersoegelse, Series II, Vol. 17-19, 1908.

Mathys M.: The Quaternary geological evolution of the Belgian Continental Shelf, southern North Sea, Ph.D. thesis, Ghent University, 382pp., http://hdl.handle.net/1854/LU-716421, 2009.

Mauz, B., Vacchi, M., Green, A., Hoffmann, G., and Cooper, A.: Beachrock: a tool for reconstructing relative sea level in the far-field, Mar. Geol., 362, 1-16, https://doi.org/10.1016/j.margeo.2015.01.009, 2015.

Meijer, T.: The late Middle Pleistocene non-marine molluscan fauna of borehole Noorderhoeve-19E117 (province of NoordHolland, the Netherlands), Cainozoic Research 2, 129-134, 2002

Meijer, T., and Preece, R. C.: Malacological evidence relating to the insularity of the British Isles during the Quaternary. Geological Society, London, Special Publications 96(1), 89-110, 1995.

Meijer, T., Pouwer, R., Cleveringa, P., de Wolf, H., Busschers, F. S., and Wesselingh, F. P.. Fossil molluscs from borehole 1750 Hollum (Ameland, the Netherlands) constrain three successive Quaternary interglacial marine intervals in the southern North Sea Basin. Netherlands Journal of Geosciences 100, 2021.

Mellett, C.L., Mauz, B., Plater, A.J., Hodgson, D.M., and Lang, A.: Optical dating of drowned landscapes: A case study from the English Channel. Quaternary Geochronology 10, 201-208. https://doi.org/10.1016/j.quageo.2012.03.012, 2012.

Mellett, C.L., Hodgson, D.M., Plater, A.J., Mauz, B., Selby, I., and Lang, A.: Denudation of the continental shelf between 1755 Britain and France at the glacial-interglacial timescale. Geomorphology 203, 79-96. https://doi.org/10.1016/j.geomorph.2013.03.030, 2013.

Meng, S., Börner, A., Menzel-Harloff, H., Strahl, J., and Müller, U.: Palaeo-ecological development and interpretation of the macrofauna inventory (Bivalvia and Gastropoda) in marine Eemian deposits at Warnow Bay (NE Germany), Quaternary International, https://doi.org/10.1016/i.quaint.2021.05.008, 2021.

1760 Menke, B.: Palynologische Untersuchungen zur Transgression des Eem-Meeres im Raum Offenbüttel/Nord-Ostsee-Kanal, Geologisches Jahrbuch A 86, 19-26, 1985. 
https://doi.org/10.5194/essd-2021-390

Preprint. Discussion started: 10 November 2021

(c) Author(s) 2021. CC BY 4.0 License.

(c) (i)

Menke. B. and Tynni, R.: Das Eeminterlazial und das Weichselfruh-glazial von Rederstall/Dithmarschen und ihre Bedeutung fur die mitteleuropaische Jungpleistozan-Gliederung, Geologisches Jahrbuch, A76, 1-109, 1984.

Miller, G.H., Hollin, J.T., and Andrews, J.T.: Aminostratigraphy of UK Pleistocene deposits. Nature, 281, 539-543, 1979.

Miller, G.H., and Mangerud, J.: Aminostratigraphy of European marine interglacial deposits, Quaternary Science Reviews, 4(4), 215-278, https://doi.org/10.1016/0277-3791(85)90002-2, 1985.

Missiaen, T., Fitch, S., Muru, M., Harding, R., Fraser, A., De Clercq, M., Garcia Moreno, D.G., Versteeg, W., Busschers, F., van Heteren, S., Hijma, M., Reichart, G.-J., and Gaffney, V.: Targeting the mesolithic: Interdisciplinary approaches to archaeological prospection in the Brown Bank area, southern North Sea, Quaternary International, 584, 141-151, 2020.

Mitchell, G.F.: The Pleistocene history of the Irish Sea. British Association for the Advancement of Science, 17, 313-325, 1960.

Mitchell, G.F.: The Pleistocene history of the Irish Sea: Second approximation. Scientific Proceedings of the Royal Dublin Society, 4(13), 1972.

Mitrovica, J. X., Gomez, N., and Clark, P. U.: The Sea-Level Fingerprint of West Antarctic Collapse, Science, 323, 753, 10.1126/science.1166510, 2009.

Monnier, J.-L., Huet, B., and Laforge, M.: Application of sedimentological analysis to correlation of eroded layers under beaches with local and regional Pleistocene stratigraphy: A contribution to geological dating of Palaeolithic sites, northern coast of Brittany, France. Quaternary International 231, 78-94. https://doi.org/10.1016/j.quaint.2010.06.033, 2011.

1780 Moreau, J., Huuse, M., Janszen, A., van der Vegt, P., Gibbard, P. L., and Moscariello, A.: The glaciogenic unconformity of the southern North Sea. Geological Society, London, Special Publications, 368(1), 99-110, 2012.

Morzadec-Kerfourn, M.T., and Monnier, J.L.: Chronologie relative des cordons littoraux pléistocènes de Bretagne. Bulletin de l'Association française pour l'étude du Quaternaire 4, 195-203, 1982.

Mottershead, D.N., Gilbertson, D.D., and Keen, D.H.: The raised beaches and shore platforms of Tor Bay: a re-evaluation.

1785 Proceedings of the Geologists’ Association, 98(3), 241-257, 1987.

Müller, H.: Pollenanalytische Untersuchungen und Jahresschichtenzahlung an der eem-zeitlichen Kieselgur von Bispingen/Luhe. Geologisches Jahrbuch A-21, 149-169, 1974.

Murchison, C.: Mastodon, elephant, rhinoceros, ossiferous caves, primeval man and his contemporaries. Palaeontological Memoirs and Notes of the Late High Falconer, Vol. II. London, 1868.

1790 Murray, A. S., and Funder, S.: Optically stimulated luminescence dating of a Danish Eemian coastal marine deposit: a test of accuracy. Quaternary Science Reviews 22(10-13), 1177-1183, 2003.

NEEM community members: Eemian interglacial reconstructed from a Greenland folded ice core. Nature, 493, 489-494, https://doi.org/10.1038/nature11789, 2013.

Nelson, A. R.: Coastal sediments, in: Handbook of Sea-Level Research, edited by: Shennan, I., Long, A.J., and Horton, B.P., 47-65, 2015. 
https://doi.org/10.5194/essd-2021-390

Preprint. Discussion started: 10 November 2021

(c) Author(s) 2021. CC BY 4.0 License.

(c) (i)

Nolf, D.: Mollusken uit het marien Kwartair te Meetkerke (West-Vlaanderen, België). Natuurwetenschappelijk Tijdschrift 55, 97-120, 1973.

Nordmann, V.: La Position stratigraphique des Depots d'Eem. Danmarks Geologiske Undersoegelse, Series II, 47 , 81pp, 1928

1800 O’Leary, M. J., Hearty, P. J., Thompson, W. G., Raymo, M. E., Mitrovica, J. X., and Webster, J. M.: Ice sheet collapse following a prolonged period of stable sea level during the last interglacial, Nature Geoscience, 6, 796-800, 2013.

Orme, A.R.: The Raised Beaches and Strandlines of South Devon. Field Studies Journal, 1(2), 15, 1960.

Ottesen, D., Dowdeswell, J. A., and Bugge, T.: Morphology, sedimentary infill and depositional environments of the Early Quaternary North Sea Basin (56-62 N). Marine and Petroleum Geology, 56, 123-146, 2014.

Otvos, E. G.: Beach ridges-definitions and significance, Geomorphology, 32, 83-108, 2000.

Paddenberg, D., Russel, J., and Tizzard, L.: Seabed Prehistory:Gauging the Effects of Marine Aggregate Dredgin - Final Report: Volume IV - Great Yarmouth. London, 2008.

Palmer, L.S., and Cooke, J.H.: The Pleistocene deposits of the Portsmouth district and their relation to man. Proceedings of the Geologists' Association, 34(4), 253-292, 1923.

Paul, M. A., Barras, B. F., and Mein, J. E.: Geotechnical properties of British estuarine clays: towards a geological framework, in: Advances in geotechnical engineering: The Skempton conference: Proceedings of a three day conference on advances in geotechnical engineering, Thomas Telford Publishing, 568-579, 2004.

Pedoja, K., Husson, L., Regard, V., Cobbold, P.R., Ostanciaux, E., Johnson, M.E., Kershaw, S., Saillard, M., Martinod, J., Furgerot, L., Weill, P., and Delcaillau, B.: Relative sea-level fall since the last interglacial stage: Are coasts uplifting worldwide? Earth-Science Reviews 108, 1-15. https://doi.org/10.1016/j.earscirev.2011.05.002, 2011.

Pedoja, K., Husson, L., Johnson, M.E., Melnick, D., Witt, C., Pochat, S., Nexer, M., Delcaillau, B., Pinegina, T., Poprawski, Y., Authemayou, C., Elliot, M., Regard, V., and Garestier, F.: Coastal staircase sequences reflecting sea-level oscillations and tectonic uplift during the Quaternary and Neogene. Earth-Science Reviews 132, 13-38. https://doi.org/10.1016/j.earscirev.2014.01.007, 2014.

Pedoja, K., Jara-Muñoz, J., de Gelder, G., Robertson, J., Meschis, M., Fernandez-Blanco, D., Nexer, M., Poprawski, Y., Dugué, O., Delcaillau, B., Bessin, P., Benabdelouahed, M., Authemayou, C., Husson, L., Regard, V., Menier, D., and Pinel, B.: Neogene-Quaternary slow coastal uplift of Western Europe through the perspective of sequences of strandlines from the Cotentin Peninsula (Normandy, France). Geomorphology 303, 338-356. https://doi.org/10.1016/i.geomorph.2017.11.021, 2018.

Peeters, J., Busschers, F. S., \& Stouthamer, E.: Fluvial evolution of the Rhine during the last interglacial-glacial cycle in the southern North Sea basin: a review and look forward. Quaternary International, 357, 176-188, 2015.

Peeters, J., Busschers, F. S., Stouthamer, E., Bosch, J. H. A., Van den Berg, M. W., Wallinga, J., Versendaal, A.J., Bunnik, F.P.M., and Middelkoop, H.. Sedimentary architecture and chronostratigraphy of a late Quaternary incised-valley fill: a 
case study of the late Middle and Late Pleistocene Rhine system in the Netherlands. Quaternary Science Reviews, 131, 211-236, https://doi.org/10.1016/j.quascirev.2015.10.015, 2016.

Peeters, J., Cohen, K. M., Thrana, C., Busschers, F. S., Martinius, A. W., Stouthamer, E., and Middelkoop, H.: Preservation of Last Interglacial and Holocene transgressive systems tracts in the Netherlands and its applicability as a North Sea Basin reservoir analogue, Earth-Sci. Rev., 188, 482-497, https://doi.org/10.1016/j.earscirev.2018.10.010, 2019.

Pellerin, J., and Dupeuble, P.A.: Le bas niveau marin éémien de Graye-sur-Mer (Calvados). Bulletin de la Société linnéenne de Normandie 107, 21-26, 1979.

Peltier, W. R.: Global glacial isostatic adjustment: palaeogeodetic and space geodetic test of the ICE-4G (VM2) model, Journal of Quaternary Science, 17, 491-510, 2002.

Penkman, K.: Aminoacid geochronology: its impact on our understanding of the Quaternary stratigraphy of the British Isles. Journal of Quaternary Science, 25(4), 501-514, 2010.

Penkman, K. E. H., Kaufman, D. S., Maddy, D., and Collins, M. J.: Closed-system behaviour of the intra-crystalline fraction of amino acids in mollusc shells, Quaternary Geochronology, 3, 2-25, http://dx.doi.org/10.1016/j.quageo.2007.07.001, 2008.

Penkman, K. E., Preece, R. C., Bridgland, D. R., Keen, D. H., Meijer, T., Parfitt, S. A., White, T. S., and Collins, M. J.: A chronological framework for the British Quaternary based on Bithynia opercula, Nature, 476, 446-449, 2011.

Penkman, K. E., Preece, R. C., Bridgland, D. R., Keen, D. H., Meijer, T., Parfitt, S. A., White, T. S., and Collins, M. J.: An aminostratigraphy for the British Quaternary based on Bithynia opercula, Quaternary Science Reviews, 61, 111-134, 2013.

Penney, D. N.: Application of Ostracoda to sea-level studies, Boreas, 16, 237-247, 1987.

Pirazzoli, P. A.: Marine terraces, Encyclopedia of Coastal Science, Springer Netherlands, Dordrecht, 632-633, 2005.

Preece, R. C.: Mollusca from Last Interglacial fluvial deposits of the River Thames at Trafalgar Square, London, Journal of Quaternary Science, 14, 77-89, 1999.

Preece, R. C.: Molluscan evidence for differentiation of interglacials within the 'Cromerian Complex', Quaternary Science Reviews, 20, 1643-1656, 2001.

Preece, R.C., Scourse, J.D., Houghton, S.D., Knudsen, K.L., and Penney, D.N.: The Pleistocene sea level and neotectonic 1855 history of the Eastern Solent, Southern England. Philosophical Transactions of the Royal Society of London B, 328, 425477, http://doi.org/10.1016/j.quaint.2010.06.033, 1990.

Prestwich, J.: On the westward extension of the old raised beach of Brighton and on the extent of the sea-bed of the same period. Quarterly Journal of the Geological Society of London 15, 215-221, 1859.

Prestwich, J.: Notes on the phenomenon of the Quaternary period in the Isle of Portland and around Weymouth. Quarterly Journal of the Geological Society of London, 31, 29-54, 1875. 
Prestwich, J.: The raised beaches and 'head' or rubble-drift of the South of England: their relation to the Valley Drifts and to the Glacial Period; and on a late post-Glacial submergence. Quarterly Journal of the Geological Society of London, 48, 263-343, 1892.

Proctor, C.J., and Smart, P.L.: A dated cave sediment record of Pleistocene transgressions on Berry Head, Southwest England. Journal of Quaternary Science, 6(3), 233-244, https://doi.org/10.1002/jqs.3390060306, 1991.

PSMSL Permanent Service for Mean Sea Level: http://www.psmsl.org/, Tide gauge data, last access 15 October 2021.

Railsback, L. B., Gibbard, P. L., Head, M. J., Voarintsoa, N. R. G., and Toucanne, S.: An optimized scheme of lettered marine isotope substages for the last 1.0 million years, and the climatostratigraphic nature of isotope stages and substages. Quaternary Science Reviews, 111, 94-106, https://doi.org/10.1016/i.quascirev.2015.01.012, 2015.

Regnauld, H., Mauz, B., and Morzadec-Kerfourn, M.T.: The last interglacial shoreline in northern Brittany, western France. Marine Geology 194, 65-77. https://doi.org/10.1016/S0025-3227(02)00699-0, 2003.

Reid, C.: A fossiliferous Pleistocene deposit at Stone, on the Hampshire coast. Quarterly Journal of the Geological Society of London, 49, 325, 1893.

Reid, C.: The Pleistocene deposits of the Sussex Coast, and their equivalents in other districts. Quarterly Journal of the Geological Society of London, 48, 344, 1892.

Reid, C.: Geology of the Country Around Bournemouth, Memoirs of the Geological Survey, England and Wales, New Series, No. 329, 1898.

Roe, H. M., Coope, G. R., Devoy, R. J. N., Harrison, C. J. O., Penkman, K. E. H., Preece, R. C., and Schreve, D. C.: Differentiation of MIS 9 and MIS 11 in the continental record: vegetational, faunal, aminostratigraphic and sea-level evidence from coastal sites in Essex, UK, Quaternary Science Reviews, 28, 2342-2373, https://doi.org/10.1016/j.quascirev.2009.04.017, 2009.

Rohling, E. J., Hibbert, F. D., Williams, F. H., Grant, K. M., Marino, G., Foster, G. L., Hennekam, R., de Lange, G. J., Roberts, A. P., Yu, J., Webster, J. M., and Yokoyama, Y.: Differences between the last two glacial maxima and implications for ice-sheet, $\delta 18 \mathrm{O}$, and sea-level reconstructions, Quaternary Science Reviews, 176, 1-28, https://doi.org/10.1016/j.quascirev.2017.09.009, 2017.

Rohling, E. J., Hibbert, F. D., Grant, K. M., Galaasen, E. V., Irvalı, N., Kleiven, H. F., Marino, G., Ninnemann, U., Roberts, A. P., Rosenthal, Y., Schulz, H., Williams, F. H., and Yu, J.: Asynchronous Antarctic and Greenland ice-volume contributions to the last interglacial sea-level highstand, Nature Communications, 10, 5040, https://doi.org/10.1038/s41467-019-12874-3, 2019.

1890 Rosentau, A., Klemann, V., Bennike, O., Steffen, H., Wehr, J., Latinović, M., Bagge, M., Ojala, A., Berglund, M., Peterson Becher, G., Schoning, K., Hansson, A., Nielsen, L., Clemmensen, L.B., Hede, M.U., Kroon, A., Pejrup, M., Sander, L., Stattegger, K., Schwarzer, K., Lampe, R., Lampe, M., Uścinowicz, S., Bitinas, A., Grudzinska, I., Vassiljev, J., Nirgi, T., Kublitskiy, Y. and Subetto, D. A: Holocene relative sea-level database for the Baltic Sea. Quaternary Science Reviews, 266, https://doi.org/10.1016/j.quascirev.2021.107071, 2021. 
https://doi.org/10.5194/essd-2021-390

Preprint. Discussion started: 10 November 2021

(c) Author(s) 2021. CC BY 4.0 License.

1895 Rovere, A., Raymo, M. E., Vacchi, M., Lorscheid, T., Stocchi, P., Gómez-Pujol, L., Harris, D. L., Casella, E., O'Leary, M. J., and Hearty, P. J.: The analysis of Last Interglacial (MIS 5e) relative sea-level indicators: Reconstructing sea-level in a warmer world, Earth-Science Reviews, 159, 404-427, https://doi.org/10.1016/j.earscirev.2016.06.006, 2016.

Rovere, A., Ryan, D., Murray-Wallace, C., Simms, A., Vacchi, M., Dutton, A., Lorscheid, T., Chutcharavan, P., Brill, D., Bartz, M., Jankowski, N., Mueller, D., Cohen, K., and Gowan, E.: Descriptions of database fields for the World Atlas of Last Interglacial Shorelines (WALIS) (Version 1,0), Zenodo [data set], https://doi.org/10.5281/zenodo.3961544, 2020.

Rühberg, N.: Landschaftsformung beim Inlandeisabbau auf Insel Usedom und Mönchgut/Rügen. Nachrichten der Deutschen Geologischen Gesellschaft, 54, 156, 1995.

Russell, J., and Tizzard, L.: Seabed Prehistory: Site Evaluation Techniques (Area 240) Synthesis, Wessex Archaeology, 2011.

1905 Sanchez-Goñi, M.F., Eynaud, F., Turon, J., Shackleton, N.J.: High resolution palynological record off the Iberian margin: direct land-sea correlation for the Last Interglacial complex. Earth and Planetary Science Letters, 171, 123-137, https://doi.org/10.1016/S0012-821X(99)00141-7, 1999.

Schreve, D. C.: Differentiation of the British late Middle Pleistocene interglacials: the evidence from mammalian biostratigraphy, Quaternary Science Reviews, 20, 1693-1705, 2001.

1910 Schulz, H., Emeis, K.-C., Winn, K., and Erlenkeuser, H.: Oberflächentemperaturen des Eem-Meeres in Schlesvig-Holsteindie UK'37-Indizien, Meyniana, 53, 163-181, 2001.

Scourse, J.D.: Late Pleistocene stratigraphy of North and West Cornwall. Transactions of the Royal Geological Society Cornwall, 22(1), 2-56, 1996.

Seidenkrantz, M. S.: Benthic foraminiferal and stable isotope evidence for a "Younger Dryas-style" cold spell at the Saalian-

1915 Eemian transition, Denmark. Palaeogeography, Palaeoclimatology, Palaeoecology, 102(1-2), 103-120, https://doi.org/10.1016/0031-0182(93)90008-7, 1993.

Selle, W.: Geologische und vegetationskundliche Untersuchungen an einigen wichtigen Vorkommen des letzen Interglazials in Nordwestdeutschland. Geologische Jahrbuch, 79, 295-352, 1962.

Selle, W., Schneekloth, H.: Ergebnisse einer Kernbohrung in Oerel, Krs. Bremervörde; drei Interstadiale über Ablagerungen des Eem-Interglazials. Zeitschrift der Deutschen Geologischen Gesellschaft, 115, 109-117, 1965.

Sha, L.P. (ed.), Schwarz, C., Maenhout van Lemberge, V, , Cameron, T.D.J., Zollmer, V., Konradi, P., Laban, C., Streif, H., Schuttenhelm, R.T.E.: Quaternary sedimentary sequences in the southern North Sea Basin. Sedimentological Working Group of the Southern North Sea Project. Commission of the European Communities (contract no. SCI* -128-C 9EDB), 1991.

1925 Shackleton, N. J.: The last interglacial in the marine and terrestrial records. Proceedings of the Royal Society of London. Series B. Biological Sciences, 174(1034), 135-154, 1969.

Shackleton, N. J., Chapman, M., Sanchez-Goñi, M. F., Pailler, D., \& Lancelot, Y. : The classic marine isotope substage 5e. Quaternary Research, 58(1), 14-16, https://doi.org/10.1006/qres.2001.2312, 2002. 
https://doi.org/10.5194/essd-2021-390

Preprint. Discussion started: 10 November 2021

(c) Author(s) 2021. CC BY 4.0 License.

(c) (i)

Shackleton, N. J., Sanchez-Goñi, M. F., Pailler, D., \& Lancelot, Y. : Marine isotope substage 5e and the Eemian interglacial. Global and Planetary change, 36(3), 151-155, https://doi.org/10.1016/S0921-8181(02)00181-9, 2003.

Shennan, I.: Flandrian sea-level changes in the Fenland I. The geographical setting and evidence of relative sea-level changes, Journal of Quaternary Science, 1, 119-154, 1986.

Shennan, I.: Holocene crustal movements and sea-level changes in Great Britain, Journal of Quaternary Science, 4, 77-89, 1989.

Shennan, I., Hamilton, S., Hillier, C., and Woodroffe, S.: A 16,000-year record of near-field relative sea-level changes, northwest Scotland, United Kingdom, Quaternary International, 133-34, 95-106, 2005.

Shennan, I., Long, A. J., and Horton, B. P.: Handbook of Sea-Level Research, John Wiley \& Sons, Ltd, Chichester, UK, 2015.

Shennan, I., Bradley, S. L., and Edwards, R.: Relative sea-level changes and crustal movements in Britain and Ireland since the Last Glacial Maximum, Quaternary Science Reviews, 188, 143-159, https://doi.org/10.1016/j.quascirev.2018.03.031, 2018.

SHOM 2020; Références Altimétriques Maritimes Ports de France métropolitaine et d'outre-mer Cotes du zéro hydrographique et niveaux caractéristiques de la marée. https://data.shom.fr/

Sier, M. J., Peeters, J., Dekkers, M. J., Pares, J. M., Chang, L., Busschers, F. S., Cohen, K.M., Wallinga, J., Bunnik, F.P.M.

1945 and Roebroeks, W.: The Blake Event recorded near the Eemian type locality? a diachronic onset of the Eemian in Europe. Quaternary Geochronology, 28, 12-28, 2015.

Sirocko, F., Seelos, K., Schaber, K., Rein, B., Dreher, F., Diehl, M., Lehne, R., Jäger, K., Krbetschek, M., and Degering, D.: A late Eemian aridity pulse in central Europe during the last glacial inception, Nature, 436, 833-836, https://doi.org/10.1038/nature03905, 2005.

1950 Southgate, G.A.: Thermoluminescence dating of beach and dune sands: potential of single-grain measurements. Nuclear Tracks, 10, 743-747, https://doi.org/10.1016/0735-245X(85)90084-5, 1985.

Sparks, B. W.: The non-marine Mollusca of the interglacial deposits at Bobbitshole, Ipswich, Philosophical Transactions of the Royal Society of London. Series B, Biological Sciences, 241, 33-44, https://doi.org/10.1098/rstb.1957.0007, 1957.

Sparks, B. W., and West, R. G.: The Interglacial Deposits at Stutton, Suffolk, Proceedings of the Geologists' Association, 1955 74(4), 419-432, 1963.

Sparks, B. W., and West, R. G.: Late Pleistocene deposits at Wretton, Norfolk. I. Ipswichian interglacial deposits, Philosophical Transactions of the Royal Society of London. Series B, Biological Sciences, 258, 1-30, https://doi.org/10.1098/rstb.1970.0030, 1970.

Straw, A.: Geomorphology of the Kirmington interglacial deposits and the Immingham channel, north Lincolnshire, Mercian $1960 \quad$ Geologist, 19, 134, 2018.

Streif, H.: Quaternary Sea-Level Changes in the North Sea, an Analysis of Amplitudes and Velocities, in: P. Brosche et al. (eds.), Earth's Rotation from Eons to Days. 201-214, https://doi.org/10.1007/978-3-642-75587-3_21, 1990 
Streif, H.: Zum Ausmass und Ablauf eustratischer Meeresspiegelschwankungen im südlichen Nordseegebiet seit Beginn des Letzten Interglazials, in: Frenzel, B. (ed.), Klimageschichtliche Probleme der letzten 130,000 Jahre. Fisher, New York, Stuttgart, 231-249, 1991.

Streif, H.: Sedimentary record of Pleistocene and Holocene marine inundations along the North Sea coast of Lower Saxony, Germany. Quaternary International, 112(1), 3-28, 2004.

Stringer, C.B., Currant, A.P., Schwarcz, H.P., and Collcutt, S.N.: Age of Pleistocene faunas from Bacon Hole, Wales. Nature, 320, 59-62, 1986.

Sundelin, U.: Fornsjöstudier inom Stångåns och Svartåns vattenområden med särskild hänsyn till den sen-och postglaciala klimatutvecklingen, PA Norstedt, 1917.

Sutcliffe, A.J., and Currant, A.P.: Minchin Hole Cave. In Wales: Gower, Preseli and Forest Fawr. Bowen, D.Q., Henry, A. (Eds). Quaternary Research Association Field Guide, Durham, 33-37, 1984.

Sutcliffe, A.J., Currant, A.P., and Stringer, C.B.: Evidence of sea-level change from coastal caves with raised beach deposits, terrestrial faunas and dated stalagmites. v. 18 (1-4), p. 243-271, 1987.

Sutherland, J. L., Davies, B. J., and Lee, J. R.: A litho-tectonic event stratigraphy from dynamic Late Devensian ice flow of the North Sea Lobe, Tunstall, east Yorkshire, UK, Proceedings of the Geologists' Association, 131, 168-186, https://doi.org/10.1016/j.pgeola.2020.03.001, 2020.

Svendsen, J. I., Alexanderson, H., Astakhov, V. I., Demidov, I., Dowdeswell, J. A., Funder, S., Gataullin, V., Henriksen, M., Hjort, C., Houmark-Nielsen, M., Hubberten, H.W., Ingólfsson, Ó., Jakobsson, M., Kjær, K.H., Larsen, E., Lokrantz, H., Lunkka, J.P., Lyså, A., Mangerud, J., Matiouchkov, A., Murray, A., Möller, P., Niessen, F., Nikolskaya, O., Polyak, L., Saarnisto, M., Siegert, C., Siegert, M.J., Spielhagen, R.F., and Stein, R.: Late Quaternary ice sheet history of northern Eurasia. Quaternary Science Reviews, 23(11-13), 1229-1271, 2004.

Tamisiea, M. E., Mitrovica, J. X., Milne, G. A., and Davis, J. L.: Global geoid and sea level changes due to present-day ice mass fluctuations, Journal of Geophysical Research-Solid Earth, 106, 30849-30863, Doi 10.1029/2000jb000011, 2001.

Tastet, J.P.: Le Pléistocène de la façade atlantique du Nord-Médoc (France): état des connaissances sur la lithologie et la chronostratigraphie des « Argiles du Gurp». Quaternaire 10. https://doi.org/10.3406/quate.1999.1643, 1999.

Thomas, G.: Late Middle Pleistocene pollen biostratigraphy in Britain: Pitfalls and possibilities in the separation of interglacial sequences, Quaternary Science Reviews, 20, 1621-1630, 10.1016/S0277-3791(01)00026-9, 2001.

1990 Törnqvist, T. E., Wallinga, J., and Busschers, F. S.: Timing of the last sequence boundary in a fluvial setting near the highstand shoreline — Insights from optical dating. Geology, 31(3), 279-282, 2003.

Toucanne, S., Zaragosi, S., Bourillet, J. F., Marieu, V., Cremer, M., Kageyama, M., Van Vliet-Lanoë, B., Eynaud, F., Turon, J.-L., and Gibbard, P. L.: The first estimation of Fleuve Manche palaeoriver discharge during the last deglaciation: Evidence for Fennoscandian ice sheet meltwater flow in the English Channel ca 20-18 ka ago. Earth and Planetary Science Letters, 290(3-4), 459-473, 2010. 
https://doi.org/10.5194/essd-2021-390

Preprint. Discussion started: 10 November 2021

(c) Author(s) 2021. CC BY 4.0 License.

Turner, C.: The Eemian interglacial in the North European plain and adjacent areas, Geologie en Mijnbouw / Netherlands Journal of Geosciences, 79, 217-231, https://doi.org/10.1017/S0016774600023660, 2000.

Turner, C.: Problems of the duration of the Eemian interglacial in Europe North of the Alps. Quaternary Research, 58(1), 4548, https://doi.org/10.1006/qres.2002.2366, 2002.

2000 Turner, C., and West, R.: The subdivision and zonation of interglacial periods, Eiszeitalter und Gegenwart, 19, $101,1968$.

Turney, C. S. M., Fogwill, C. J., Golledge, N. R., McKay, N. P., van Sebille, E., Jones, R. T., Etheridge, D., Rubino, M., Thornton, D. P., Davies, S. M., Ramsey, C. B., Thomas, Z. A., Bird, M. I., Munksgaard, N. C., Kohno, M., Woodward, J., Winter, K., Weyrich, L. S., Rootes, C. M., Millman, H., Albert, P. G., Rivera, A., van Ommen, T., Curran, M., Moy, A., Rahmstorf, S., Kawamura, K., Hillenbrand, C.-D., Weber, M. E., Manning, C. J., Young, J., and Cooper, A.: Early Last Interglacial ocean warming drove substantial ice mass loss from Antarctica, Proceedings of the National Academy of Sciences, 117, 3996-4006, https://doi.org/10.1073/pnas.1902469117, 2020.

Tzedakis, C.: Timing and duration of Last Interglacial conditions in Europe: a chronicle of a changing chronology, Quaternary Science Reviews, 22, 763-768, https://doi.org/10.1016/S0277-3791(03)00004-0, 2003.

Tzedakis, P. C., Drysdale, R. N., Margari, V., Skinner, L. C., Menviel, L., Rhodes, R. H., Taschetto, S., Hodell, D. A., Crowhurst, S. J., Hellstrom, J. C., Fallick, A. E., Grimalt, J. O., McManus, J. F., Martrat, B., Mokeddem, Z. , Parrenin, F. , Regattieri, E., Roe, K., and Zanchetta, G.: Enhanced climate instability in the North Atlantic and southern Europe during the Last Interglacial. Nature communications, 9(1), 1-14, https://doi.org/10.1038/s41467-018-06683-32018, 2018.

Ussher, W.A.E.: The post-tertiary geology of Cornwall. Stephen Austin and Sons, Hertford, 1879.

Van de Meene, E.A., and Zagwijn, W.H.: Die Rheinläufe im deutsch-niederländischen Grenzgebiet seit der Saale-Kaltzeit: Überblick neuer geologischer und pollenanalytischer Untersuchungen, Fortschritte in der Geologie von Rheinland und Westfalen, 28, 345-359, 1978.

Van de Plassche, O.: Evolution of the intra-coastal tidal range in the Rhine-Meuse delta and Flevo Lagoon, 5700-3000 yrs cal BC. Marine Geology, 124(1-4), 113-128, 1995.

Van de Plassche, O.: Sea-level change and water movements in the Netherlands during the Holocene, Mededelingen Rijks Geologische Dienst, 36, 1-93, 1982.

Van de Plassche, O.: Sea-Level Research: a manual for the collection and evaluation of data, GeoBooks, Norwich, 618 pp., 1986.

Van Leeuwen, R. J., Beets, D. J., Bosch, J. H. A., Burger, A. W., Cleveringa, P., Harten, D. V., Herngreen, G.F.W., Kruk, R.W., Langereis, C.G., Meijer, T., and Pouwer, R.: Stratigraphy and integrated facies analysis of the Saalian and Eemian sediments in the Amsterdam-Terminal borehole, the Netherlands. Netherlands Journal of Geosciences/Geologie en Mijnbouw, 79(2/3). 161-196, https://doi.org/10.1017/S0016774600023647, 2000.

Van Vliet-Lanoë, B., Laurent, M., Bahain, J.L., Balescu, S., Falguères, C., Field, M., Hallégouët, B., and Keen, D.H.: Middle Pleistocene raised beach anomalies in the English Channel: regional and global stratigraphic implications. Journal of Geodynamics 29, 15-41. https://doi.org/10.1016/S0264-3707(99)00063-0, 2000. 
https://doi.org/10.5194/essd-2021-390

Preprint. Discussion started: 10 November 2021

(c) Author(s) 2021. CC BY 4.0 License.

(c) (i)

2030 Van Vliet-Lanoë, B., Cliquet, D., Auguste, P., Folz, E., Keen, D., Schwenninger, J.-L., Mercier, N., Alix, P., Roupin, Y., Meurisse, and M., Seignac, H.: L'abri sous-roche du Rozel (France, Manche): un habitat de la phase récente du Paléolithique moyen dans son contexte géomorphologique. Quaternaire 17, 207-258. https://doi.org/10.4000/quaternaire.826, 2006.

Vandenberghe, J.: Paleoenvironment and stratigraphy during the Last Glacial in the Belgian-Dutch border region. Quaternary Research, 24(1), 23-38, 1985.

Vink, A., Steffen, H., Reinhardt, L., and Kaufmann, G.: Holocene relative sea-level change, isostatic subsidence and the radial viscosity structure of the mantle of northwest Europe (Belgium, the Netherlands, Germany, southern North Sea). Quaternary Science Reviews, 26(25-28), 3249-3275, 2007.

Vis, G. J., Cohen, K. M., Westerhoff, W. E., Veen, J. H. T., Hijma, M. P., van der Spek, A. J., \& Vos, P. C.: Paleogeography, in: Handbook of sea-level research, edited by: Shennan, I., Long, A. J., and Horton, B. P., John Wiley \& Sons, Ltd, Chichester, UK, 514-535, 2015.

Wallinga, J., Törnqvist, T. E., Busschers, F. S., and Weerts, H. J.: Allogenic forcing of the late Quaternary Rhine-Meuse fluvial record: the interplay of sea-level change, climate change and crustal movements. Basin Research, 16(4), 535-547, 2004.

2045 Wesselingh, F., Visser, P., Meijer, T.: Het Eemien in zuidelijk Flevoland: een blik in de bodem van het bekken van Amersfoort. Afzettingen WTKG 31(4), 2010.

West, R.: A note on pollen analyses from the Speeton shell bed, Proceedings of the Geologists' Association, 80, 217-218, 1969.

West, R. G.: Pleistocene Geology and Biology, Longman, 1977.

West, R. G., and Godwin, H.: Interglacial deposits at Bobbitshole, Ipswich, Philosophical Transactions of the Royal Society of London B: Biological Sciences, 241, 1-31, https://doi.org/10.1098/rstb.1957.0006, 1957.

West, R.G., and Sparks, B.W.: Coastal interglacial deposits of the English Channel. Philosophical Transactions of the Royal Society of London B, 243, 95-133, 1960.

West, R. G., Andrew, R., Catt, J. A., Hart, C. P., Hollin, J. T., Knudsen, K. L., Miller, G., Penney, D. N., Pettit, M., Preece, R. C., Switsur, V. R., Whiteman, C. A., and Zhou, L. P.: Late and Middle Pleistocene deposits at Somersham, Cambridgeshire, U.K.: a model for reconstructing fluvial/estuarine depositional environments, Quaternary Science Reviews, 18, 1247-1314, 1999.

Westaway, R., Maddy, D., and Bridgland, D.: Flow in the lower continental crust as a mechanism for the Quaternary uplift of south-east England: constraints from the Thames terrace record. Quaternary Science Reviews, 21(4-6), 559-603, 2002.

2060 Westaway, R., Bridgland, D., and White, M.: The Quaternary uplift history of central southern England: evidence from the terraces of the Solent River system and nearby raised beaches. Quaternary Science Reviews, 25(17-18), 2212-2250, 2006. 
https://doi.org/10.5194/essd-2021-390

Preprint. Discussion started: 10 November 2021

(c) Author(s) 2021. CC BY 4.0 License.

(c) (i)

Weston, C.H.: On the sub-escarpments of the Ridgeway Range and their contemporary deposits in the Isle of Portland. Quarterly Journal of the Geological Society of London, 8, 110-120, 1852.

Whitaker, W. S., J., S. B., and J., J.-B. A.: The geology of south-western Norfolk and of northern Cambridgeshire. (Explanation of sheet 65), Printed for H.M. Stationary Off., by Eyre and Spottiswoode, London, 1893.

Wilson, S. J.: The correlation of the Speeton Shell Bed, Filey Bay, Yorkshire, to an oxygen isotope stage, Proceedings of the Yorkshire Geological Society, 48, 223-226, 10.1144/pygs.48.3.223, 1991.

Winn, K., and Erlenkeuser, H.: Das Eem Meer in Norddeutschland: Die Kernbohrungen bei Dagebüll-Erstergebnisse. Meyniana, 47, 101-113, https://doi.org/10.2312/meyniana.1995.47.101, 1995.

Winn, K. and Erlenkeuser, H., (Eds.): Das Eem-Meer in Norddeutschland und angrenzenden Gebieten: Aufbau einer stratigraphischen Feingliederung und Untersuchung der palaeohydrographischen Entwicklung nach isotopischen, sedimentologischen, geochemischen und faunistischen Kriterien Abschlussbericht zum DFG-Forschungsvorhaben Wi 1322/1-1,-2. Christian-Albrechts-Universitaet, Kiel, Germany, 1998.

Winn, K, Glos, R., Averdieck, F.-R, and Erlenkeuser, H.: On the age of the marine Eem in northwestern Germany. Geologos 5, 41-56, 2000.

Wiśniewski, B., Wolski, T., \& Giza, A. (2014). Adjustment of the European Vertical Reference System for the representation of the Baltic Sea water surface topography. Zeszyty Naukowe/Akademia Morska w Szczecinie.

Woodroffe, S. A., and Barlow, N. L.: Reference water level and tidal datum, in: Handbook of sea-level research, edited by:

Shennan, I., Long, A. J., and Horton, B. P., John Wiley \& Sons, Ltd, Chichester, UK, 171-180, 2015.

Woodward, H.B., Blake, J.H., Bristow, H.W., Rutley, F., and Ussher, W.A.E.: Geology of the east Somerset and the Bristol Coalfields. Memoirs of the Geological Survey, London, 1876.

Wöppelmann, G., Pouvreau, N., Coulomb, A., Simon, B., Woodworth, P.L.: Tide gauge datum continuity at Brest since 1711: France's longest sea-level record. Geophysical Research Letters, 35(22), https://doi.org/10.1029/2008GL035783, 2008

Yokoyama, Y., and Purcell, A.: On the geophysical processes impacting palaeo-sea-level observations, Geoscience Letters, 8, 13, 10.1186/s40562-021-00184-w, 2021.

Zagwijn, W. H.: Vegetation, climate and radiocarbon datings in the late Pleistocene of the Netherlands: I. Eemian and early Weichselian. Mededelingen van de Geologische Stichting Nieuwe Serie 14, pp. 15-45, 1961

Zagwijn, W. H.: Sea-level changes in the Netherlands during the Eemian. Geologie en Mijnbouw, 62, p. 437-450, 1983.

Zagwijn, W. H.: An analysis of Eemian climate in western and central Europe. Quaternary Science Reviews, 15(5-6), 451469, https://doi.org/10.1016/0277-3791(96)00011-X, 1996.

Zecchin, M., Nalin, R., and Roda, C.: Raised Pleistocene marine terraces of the Crotone peninsula (Calabria, southern Italy): facies analysis and organization of their deposits, Sediment. Geol., 172, 165-185, 2004.

2095 Zeuner, F.E.: Cervus elaphus jerseyensis and other fauna in the $25 \mathrm{ft}$ beach of Belle Hougue Cave, Jersey, C. I. Bulletin de la Société Jerseiaise, 14, 238-254, 1946. 
https://doi.org/10.5194/essd-2021-390

Preprint. Discussion started: 10 November 2021

(C) Author(s) 2021. CC BY 4.0 License.

(c) (i)

Zong, Y., and Horton, B. P.: Diatom zones across intertidal flats and coastal saltmarshes in Britain, Diatom Research, 13, 375-394, 1998. 